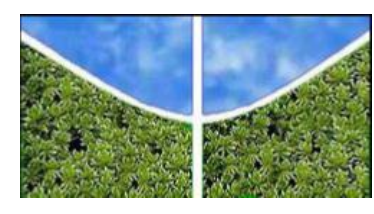

UNIVERSIDADE DE BRASÍLIA

FACULDADE DE EDUCAÇÃO

PROGRAMA DE PÓS-GRADUAÇÃO EM EDUCAÇÃO

\title{
MANIFESTAÇÕES CULTURAIS: A CONGADA COMO ESPAÇO EDUCATIVO DOS JOVENS DE PINHÕES - MG
}

Wanessa Ferreira de Sousa

Orientação da Profa. Dra. Patrícia Lima Martins Pederiva

Brasília, março de 2015. 


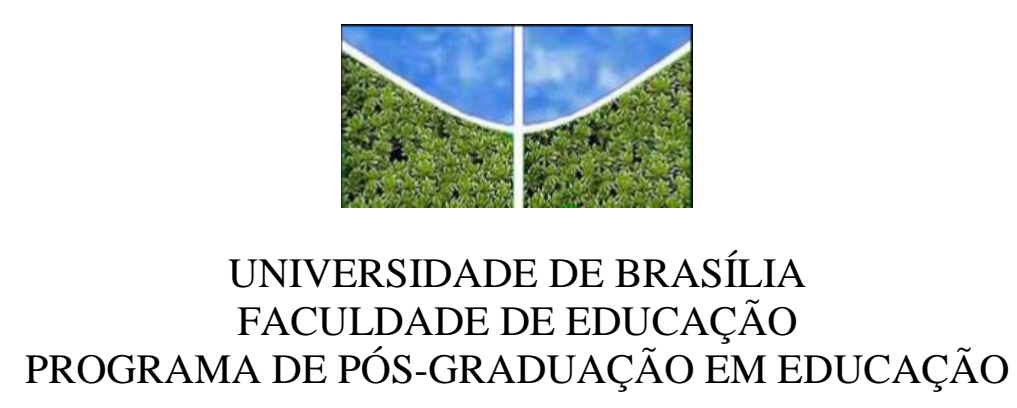

\title{
MANIFESTAÇÕES CULTURAIS: A CONGADA COMO ESPAÇO EDUCATIVO DOS JOVENS DE PINHÕES - MG
}

\author{
Wanessa Ferreira de Sousa
}

Dissertação apresentada ao Programa de Pós-Graduação em Educação da Faculdade de Educação da Universidade de Brasília/UnB como parte dos requisitos para obtenção do título de Mestre em Educação - Linha de pesquisa: Escola, Aprendizagem, Ação Pedagógica e Subjetividade na Educação. Eixo de interesse: Processos de Escolarização.

Orientadora: Profa. Dra. Patrícia Lima Martins Pederiva.

Brasília, março de 2015. 


\section{Banca examinadora:}

Profa. Dra. Patrícia Lima Martins Pederiva (Orientadora)

Faculdade de Educação - FE/PPGE/Universidade de Brasília - UnB

Profa. Dra. Elizabeth Tunes

Faculdade de Educação - FE/PPGE/Universidade de Brasília - UnB

Profa. Dra. Ingrid Lilian Fuhr Raad

Psicologia/FACES/Centro Universitário de Brasília - UniCeub

Profa. Dra. Maria Helena da Silva Carneiro

Faculdade de Educação - FE/PPGE/Universidade de Brasília - UnB 
À minha família, Anderson e Lucas, que, com carinho e apoio, contribuíram de modo inestimável para a realização deste trabalho. 


\section{AGRADECIMENTOS}

A Deus, que sempre se fez presente em minha vida.

À minha mãe, por sempre incentivar o meu gosto pelos estudos, mesmo com todas as dificuldades que isso significava para nossa família.

Ao GEPPE, com seus antigos e novos integrantes, que proporcionou ricos momentos de estudo e aprendizagem.

Aos meus professores da UFMG, onde conclui a graduação, principalmente Luiz Carlos Villalta, Marcelo Magalhães Godoy e Alexandre Mendes Cunha, por me permitirem iniciar um caminho na pesquisa acadêmica.

Aos meus professores da UnB, Raquel Moraes, Fernanda Müller e Lúcio Teles, que contribuíram para o meu crescimento acadêmico e para o desenvolvimento do meu trabalho.

À professora Elizabeth Tunes, que é para mim a figura de uma mestra por excelência e que, com seus pensamentos e palavras inspiradoras, encorajou-me a colocar em prática o meu projeto.

À minha companheira e amiga Milena Pimenta, que compartilhou comigo angústias, dificuldades e alegrias ao longo desses dois anos de estudo, pesquisa e escrita.

À professora Patrícia Pederiva, exímia orientadora, por ter me acolhido e me orientado com sua força, coragem e dedicação durante o percurso do mestrado. 


\section{RESUMO}

Este trabalho propôs-se a investigar as relações que a juventude estabelece com os processos educativos caracterizados por trocas de saberes, crenças e tradições no espaço da manifestação cultural da congada no remanescente de quilombo em Pinhões - MG. Como objetivos específicos, buscou-se investigar o que é a juventude e de que modo ela se relaciona com a cultura e com a educação; identificar quais são as crenças, os saberes e as tradições trocadas no ambiente da congada; compreender o que os adultos esperam do jovem e o que estes esperam de si mesmos quanto à sua ligação com a tradição. Os instrumentos metodológicos utilizados foram a entrevista, o grupo focal e a observação. Foram entrevistados três adultos (dois mestres da congada e uma moradora da comunidade) e cinco jovens. Os dados coletados foram transcritos e analisados. Por meio da análise realizada, foi possível identificar que as práticas educativas que acontecem naquele ambiente cultural, envolvendo adultos e jovens, estão fortemente ligadas à conservação das crenças, saberes e valores que configuram a tradição local. Os adultos afirmaram esperar dos jovens que carreguem a tradição para o futuro sem alterá-la. Os jovens, por sua vez, reconheceram as tradições como algo valoroso, afirmaram manter contato com ela por vontade própria e demonstraram o desejo de conservá-la, mesmo que imprimam-na características novas. Foi possível identificar que, naquele ambiente, os princípios que norteiam a educação dos jovens estão assentados na vontade e na liberdade e que, ao carregarem as tradições para o futuro, os jovens o fazem por escolha e não por imposição.

Palavras-chave: manifestações culturais, congada, práticas educativas, juventude, tradição. 


\begin{abstract}
This work aimed to investigate the relationships that youth establishes with the educational processes characterized by exchanges of knowledge, beliefs and traditions in the space of cultural manifestation of congada in Quilombo remaining in Pine - MG. The specific objectives, we sought to investigate what is the youth and so it is related to culture and education; identify what are the beliefs, knowledge and traditions transmitted in the congada environment; understand what adults expect the young and what they expect of themselves for their binding to the tradition. The methodological tools used were interviews, focus groups and observation. We interviewed three adults (two masters of congada and a resident community) and five young adults. The collected data were transcribed and analyzed. Through the analysis, we found that the educational practices that take place in that cultural environment involving adults and young people are strongly linked to the conservation of beliefs, knowledge and values that shape the local tradition. The adults said they hoped the young people who carry the tradition into the future without changing it. Young people, in turn, recognized the traditions as something valuable, they said that the kept the contact to her at willing and demonstrating the desire to keep it, even printing on the new features. We found that, in that environment, the principles that guide the education of young people sit in the will and freedom and that, by uploading the traditions for the future, young people do by choice and not by imposition.
\end{abstract}

Key-words: cultural events, congada, educational practices, youth, tradition. 


\section{LISTA DE FIGURAS}

Figura 1 - Representação da relação jovens, adultos e educação.............................................53

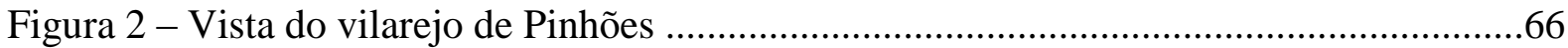

Figura 3 _ Capela de Nossa Senhora do Rosário, em Pinhões - MG ....................................67

Figura 4 - Festa de Nossa Senhora do Rosário, em 19 de outubro de 2014 .......................... 68

Figura 5 - Grupo de congada organizando sua formação.....................................................69 


\section{LISTA DE SIGLAS}

ECA Estatuto da Criança e do Adolescente

IBGE Instituto Brasileiro de Geografia e Estatística

OMC Organização Mundial do Comércio

OMS Organização Mundial da Saúde

ONU Organização das Nações Unidas

UNESCO Organização das Nações Unidas para a Educação, a Ciência e a Cultura

UNFPA Fundo de População das Nações Unidas 


\section{SUMÁRIO}

Introdução

CAPÍTULO I: AS INTERFACES ENTRE JUVENTUDE, EDUCAÇÃO E CULTURA......15

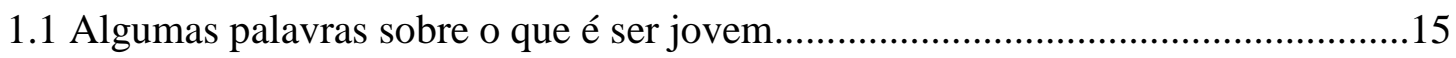

1.2 A juventude sob o olhar do pesquisador brasileiro.............................................24

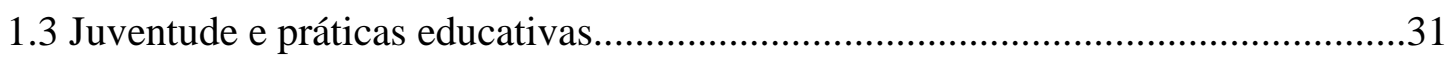

CAPÍTULO II: A CULTURA COMO ESPAÇO DE INVESTIGAÇÃO..............................40

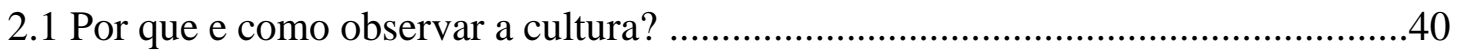

$2.2 \mathrm{O}$ jovem em sua relação com a cultura................................................................46

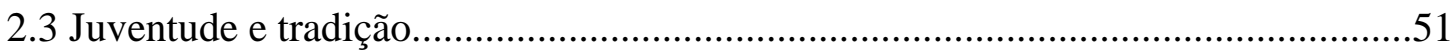

CAPÍTULO III: ELEMENTOS TRADICIONAIS NA CONGADA.................................... 55

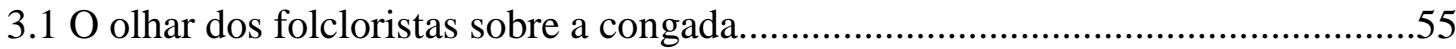

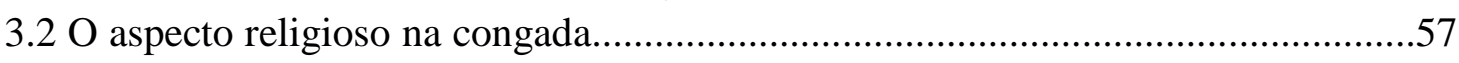

3.3 A congada como festa de devoção dos negros......................................................60

CAPÍTULO IV: A COMUNIDADE DE PINHÕES - UM LUGAR, UM CAMINHO..........64

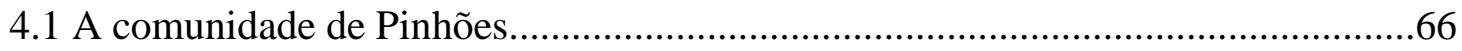

$4.2 \mathrm{O}$ grupo de congada de Pinhões...................................................................68

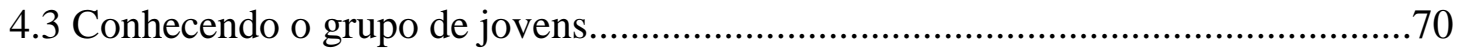

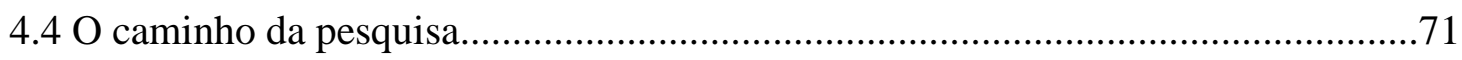

4.5 Jovens da congada de Pinhões: Quem são? Por que são?.......................................73

4.5.1 As gerações depois da nossa................................................................73

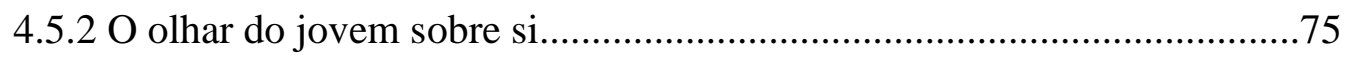

4.5.3 O jovem segundo o meio em que vive.....................................................76

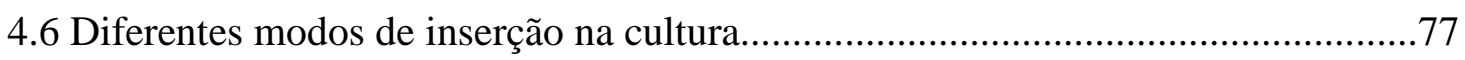

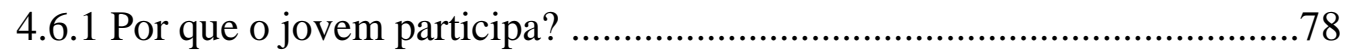

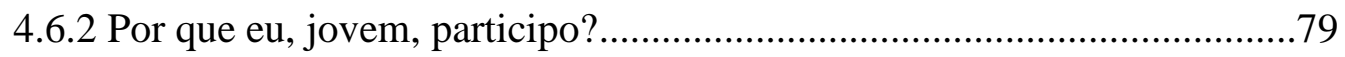

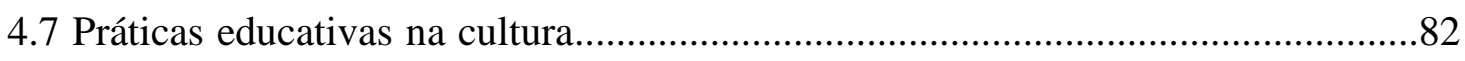

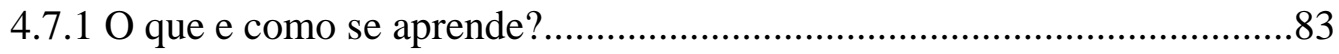

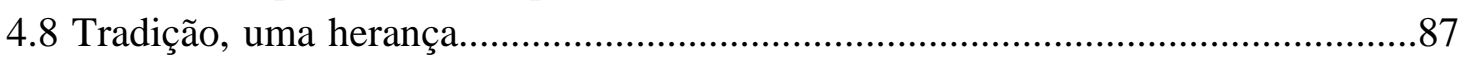

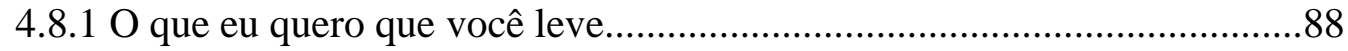

4.8.2 O que eu levo e como quero levar.......................................................89

4.8.3 Ser quilombola, ser negro..............................................................93

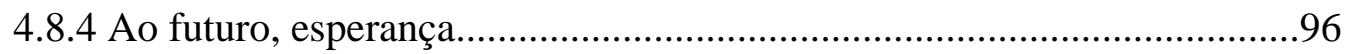

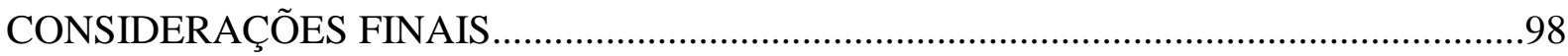

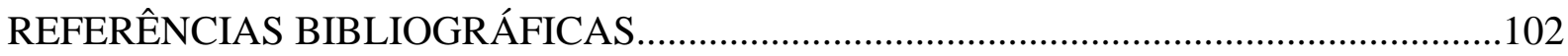




\section{INTRODUÇÃO}

Ao iniciar este trabalho, julguei necessário trazer um pouco da minha história de vida e formação, a fim que fosse compreensível a quem o lesse os motivos que me levaram à escolha do tema abordado bem como do tratamento que foi dado a ele nas linhas que seguem. Acredito que, na verdade não escolhemos um tema de pesquisa, mas procuramos respostas para nossas inquietações pessoais diante da vida e do caminho que escolhemos seguir. Meu tema de pesquisa está ligado ao que vivi na infância e na juventude, à minha formação acadêmica e à profissão que tomei como minha.

Primeiramente, durante a infância e juventude, que se deu parte no interior de Minas Gerais e parte na periferia de Belo Horizonte, a grande metrópole mineira, pude estar em contato com ambientes culturais muito ricos. No interior havia a beleza das rezas, das festas religiosas e folclóricas, das quais eu participava mesmo sem compreender direito seu contexto. As comidas, os causos, a proximidade das pessoas, a solidariedade e a mobilização deixaram para a vida adulta a certeza de que é possível uma vida feliz e simples, convivendo com aqueles que partilham valores e desejos semelhantes.

Na cidade de Belo Horizonte, o ambiente da periferia foi o lugar de encontro com pessoas das mais diferentes regiões do país e com costumes bem distintos. Nessa época pude perceber, mesmo sem um olhar mais apurado, a riqueza da diversidade. No bairro onde vivi até os 25 anos, havia também as festas ligadas à liturgia católica, festas religiosas nas quais uma infinidade de tradições populares era posta em prática ao longo do ano. Visitávamos os presépios vizinhos, fazíamos caravana ao Presépio do Pipiripau. Sem dúvida, uma infância bastante rica. Muitas informações contidas nas canções, nas imagens, nas rezas, o gosto das comidas, o prazer da companhia das pessoas nos festejos nunca saíram de minha memória.

Na década de 1990, preocupava-me a violência e a falta de perspectiva de que sofria boa parte dos jovens que haviam crescido na periferia comigo. Poucas eram as oportunidades de sair das condições precárias em que vivíamos e daquele estado de letargia em que as pessoas por vezes se encontravam. Via, em alguns dos meus professores, bons conselheiros nesse sentido. Pessoas que, para além do conteúdo que ministravam na escola, pediam que fôssemos mais críticos e ativos. Todas essas condições associadas me fizeram optar pelo 
estudo da História, a fim de compreender o ambiente que estava à minha volta e talvez contribuir para manter o que me parecia saudável e transformar o que era necessário.

Ao ingressar na Universidade Federal de Minas Gerais, tive então contato com pessoas que para mim foram mais que professores, foram mestres ao estilo do mestre que tantas vezes ouvi nas falas de Tunes e Pederiva" durante nossos debates acerca da "Escola e seu significado social". Aquele mestre que abre uma janela e mostra certa direção na qual você pode seguir se assim desejar. Compreendi que a História como estava escrita até bem pouco tempo privilegiava apenas os feitos dos grandes heróis e das grandes personagens sem, contudo, levar em conta que o povo comum também fazia a História. Tive a felicidade de estudar a partir dos debates que valorizavam os acontecimentos pequenos que, somados, construíam a teia da história humana.

Aprendi, com essa trajetória acadêmica, a valorizar as vivências culturais, o cotidiano, o simples. E também a tomar gosto pela pesquisa e pela educação (em seu sentido amplo), que me pareciam, e ainda parecem, caminhos possíveis para tomar consciência da realidade fazendo aqui uma alusão ao mito da caverna -, e pôr em prática ações que ajudem a aprimorar o conhecimento e a própria condição humana. Paralelamente à graduação, comecei a trabalhar como voluntária em um curso comunitário de educação de jovens e adultos, lecionando História.

Após concluir a licenciatura, permaneci em um grupo que se dedicava às pesquisas do século XVIII e XIX no contexto mineiro e continuei trabalhando com educação, porém na rede pública estadual de MG com alunos dos ensinos fundamental e médio. Foi nesse período em que tive uma das experiências mais ricas como profissional e ser humano: o trabalho como professora de jovens do Ensino Médio em uma escola inserida na comunidade considerada um remanescente de quilombo, Pinhões, que fica na região metropolitana de Belo Horizonte. As discussões que pude propor aos meus alunos e amigos foram muito além do que eu poderia fazer se me limitasse a trabalhar a História como um conteúdo curricular. Entrei no cotidiano daquelas pessoas e pude perceber a riqueza que os cercava.

Em Pinhões há um grupo de congada do qual participam crianças, jovens e adultos, que se reúne para trocar conhecimentos sobre essa manifestação cultural. A culminância dessas reuniões é a festa de Nossa Senhora do Rosário, em outubro, quando toda a

\footnotetext{
${ }^{1}$ Professoras doutoras que ministraram a disciplina mencionada na Faculdade de Educação FE-Unb, no ano de 2012
} 
comunidade festeja. Durante minha estadia nessa comunidade, que durou três anos, participei dos encontros e das festas. Mantive um contato próximo com aquelas pessoas. Conheci famílias que fabricavam panelas de barro e outros artesanatos, experimentei seus pratos e compartilhei de muitos momentos agradáveis.

A convivência no quilombo foi marcante, despertou meu olhar novamente para a religião, as tradições, as questões étnicas ligadas à condição de descendência escrava, entre tantas outras. Em resumo, eu via a História acontecendo ali, de um modo muito especial. O quilombo me lembrava das vivências culturais de minha infância. Ao conversar com algumas pessoas da comunidade, pude notar que compartilhavam com os mais jovens seus saberes, que não eram poucos, suas crenças, suas tradições.

Havia naquela comunidade, a meu ver, com sua população simples, mas rica saberes e em cultura, um espaço privilegiado de educação em que aprender e ensinar associava-se à própria vida, às necessidades da comunidade. Eu imaginava, naquela época e também agora, que a educação deveria ser semelhante ao que acontecia ali: algo espontâneo, baseado na liberdade, no acolhimento da diferença.

Quando decidi voltar aos estudos, após alguns anos fora da universidade, tive a oportunidade de conviver com as professoras Elizabeth Tunes e Patrícia Pederiva. Já havia ouvido falar de seu grupo de estudos por meio de colegas que estavam na graduação de Pedagogia. Consegui então participar da disciplina "A escola e seu significado social". Durante as leituras e os debates, todas as minhas inquietações com relação à educação voltaram à tona.

Já cursando o mestrado, todas essas questões que haviam perpassado minha trajetória se condensaram em uma proposta de estudo. Minha intenção foi, desde o início, buscar compreender os processos educativos que ocorriam em outros ambientes, fora dos muros da escola. Acreditava e ainda acredito que a educação está baseada em uma troca de saberes e é algo que acontece com os seres humanos desde os primórdios de sua existência. Antes mesmo que houvesse instituições com o objetivo específico de educar, nós humanos já aprendíamos e ensinávamos uns aos outros aquilo que era o legado humano na Terra, o que queríamos conservar.

Para fazer este trabalho então, propus-me a conversar com alguns jovens de Pinhões, com os mestres da congada e com moradores do vilarejo e observar o cotidiano deles a fim de 
coletar informações que fossem capazes de dizer algo sobre o que é a juventude e o modo como ela se relaciona com a cultura e com as práticas educativas existentes nesse meio. Acredito que os jovens são fundamentais na tarefa de conservar as tradições sem, contudo, deixar de modificá-las, imprimindo a elas sua visão de mundo. A chave de compreensão da educação, a meu ver, reside na necessidade que o ser humano tem de preservar aquilo que já foi descoberto, desenvolvido, aperfeiçoado por meio da transmissão dos conhecimentos às novas gerações.

Essa necessidade de transmitir saberes desenvolvidos ao longo dos milhares de anos de existência humana acabou sendo institucionalizada na escola. Contudo, muito antes de existirem escolas, já existia a educação em seu sentido amplo (envolvendo tudo o que se aprende e se ensina nos mais diferentes contextos e com as mais diversas finalidades). $\mathrm{O}$ intuito aqui é voltar o olhar para as práticas educativas que ocorrem em um ambiente cultural, onde estão presentes saberes tradicionais, e observar de que modo o jovem se relaciona com eles. Que papel é atribuído a esses jovens pelos mais velhos? Que papel o jovem atribui a si mesmo nesse contexto? Caminhemos, então, para a tarefa de responder aos seguintes objetivos: geral - investigar as relações que a juventude estabelece com os processos educativos caracterizados por trocas de saberes, crenças e tradições no espaço da manifestação cultural da congada no remanescente de quilombo em Pinhões - MG; específicos - $1^{\circ}$ Investigar o que é a juventude e de que modo ela se relaciona com a cultura e com a educação; $2^{\circ}$ Identificar quais são as crenças, saberes e tradições trocadas no ambiente da congada; $3^{\circ}$ Compreender o que os adultos esperam do jovem e o que estes esperam de si mesmos quanto à sua ligação com a tradição. 


\section{CAPÍTULO I: INTERFACES ENTRE JUVENTUDE CULTURA E EDUCAÇÃO}

Quem é o jovem? De que modo ele se relaciona com os adultos no âmbito da cultura e, mais especificamente, das manifestações culturais tradicionais? $\mathrm{O}$ que os adultos esperam dele? Que tipo de educação o jovem pode receber nesse contexto e com que intuito isso se dá? Essas questões fundamentam a primeira parte deste trabalho. O jovem (e também a criança e o adolescente) para o qual se dirigem os processos educativos é guardião das possibilidades de responder ao que se espera dele, de rebelar-se, de criar algo novo ou conservar aquilo que já foi construído, imprimindo ao mundo o seu modo de ser.

\subsection{Algumas palavras sobre o que é ser jovem}

Definir o que é juventude ou quem é o jovem é uma tarefa bastante difícil. Esse não é um tema novo e, ao investigarmos o caminho percorrido pelo conceito, é possível perceber as mudanças de olhar guiadas tanto pelas modificações que ocorrem dentro dos campos de conhecimento como a sociologia e a antropologia, quanto pelas transformações históricas, sociais e culturais que levam a entendimentos distintos sobre esse tema em diferentes partes do mundo.

Um fator costuma ser mencionado na literatura como marco definidor do que é a juventude: a questão etária - não apenas do ponto de vista biológico, pelo qual se reconhece a juventude como uma fase que tem seu início na puberdade e termina com o ingresso definitivo na vida adulta, período em há uma maturação do organismo, mas também do ponto de vista sociológico, por meio do qual é vista como uma das fases da vida, que não é mais infância e também não é o universo dos adultos - trata-se de um tempo de adaptação e preparo para a imersão definitiva nas regras sociais.

De acordo com Groppo (2000, p. 271), “a nossa concepção de juventude ainda é marcada por caracteres definidores e legitimadores cientificistas, baseadas em uma noção evolucionista do ser humano e das coisas", por isso ainda é muito comum encontrar uma definição de juventude como período intermediário entre a infância e a vida adulta, que geralmente é demarcado por idades. 
É necessário termos cautela quanto à utilização de qualquer marco definidor da juventude, seja em termos de idade ou de questões relacionadas à imersão nas regras sociais, pois, no entendimento atual, ser jovem envolve diversas outras dimensões que não se resumem às que Groppo (2000, p. 271) chamou de "cientificistas" e "evolucionistas". Ao trabalharmos hoje com o termo juventude, é preciso levar em consideração que ele abarca diferentes concepções e olhares.

Kehl (2004, p. 89-90) salienta que "a juventude é um estado de espírito, é um jeito de corpo, é um sinal de saúde e disposição, é um perfil consumidor, uma fatia do mercado onde todos querem se incluir", remetendo-se à dilatação da noção do que é ser jovem, que perpassa os estudos mais recentes. É necessário consideramos essas múltiplas dimensões que envolvem a palavra juventude e o grande número de possibilidades de definição, recortes e análises aos quais ela remete.

De qualquer modo, devemos mencionar que a literatura não abandonou a delimitação etária; esta ainda é uma das bases para a definição da condição juvenil. Nos documentos de organismos internacionais, que costumam ser o ponto de partida de muitas produções acadêmicas, como a OMS (Organização Mundial de Saúde) e a UNESCO (Organização das Nações Unidas para a Educação, a Ciência e a Cultura), existe uma delimitação etária para dizer quem são os jovens.

Barber-Maden e Saber (2010, p. 19) informam que há "um conceito amplamente aceito, formulado pela OMS, que distingue a juventude por um recorte etário, considerando-se jovem aquela pessoa entre 15 e 24". O documento da UNESCO de 2004 sobre políticas públicas e juventude, por sua vez, confirma que

Do ponto de vista demográfico, os jovens são, principalmente, um grupo populacional que corresponde a uma determinada faixa etária que varia segundo contextos particulares, mas que, geralmente, está localizada entre os 15 e os 24 anos de idade. No caso de áreas rurais ou de pobreza extrema, o limite se desloca para baixo e inclui o grupo de 10 a 14 anos; em estratos sociais médios e altos urbanizados se amplia para cima para incluir o grupo de 25 a 29 anos. Segundo diversas circunstâncias particulares, identifica-se, como jovens, um conjunto de pessoas de idades variáveis que não pode ser tratado com começo e fim rígidos (UNESCO, 2004, p. 25). 
Os organismos internacionais, e mesmo alguns órgãos governamentais, como o Instituto Brasileiro de Geografia e Estatística (IBGE), utilizam tais dados para pesquisas do tipo demográficas, que são importantes, sobretudo, para compreender dados mais gerais sobre os jovens em uma determinada sociedade. Estudos desse tipo podem contribuir para compreender situações relacionadas a educação, trabalho, saúde, violência, entre outros, propiciando aos agentes sociais e mesmo ao governo informações que apontam para a necessidade de estabelecimento de políticas públicas adequadas.

Segundo Groppo (2000, p. 9), “o critério etário - que delimita a juventude de acordo com faixas de idade, de 15 a 21 anos, de 10 a 24 anos, de 14 a 19 anos etc. - está sempre presente, expresso ou subjacente, como base prévia de uma definição de juventude". Há muitas variações sobre onde começaria e terminaria essa fase da vida em termos etários, e tal fato leva a um "extremo relativismo" (Ibidem, p. 10). É difícil precisar um limite etário e utilizá-lo como único critério definidor por diversas questões, que estão relacionadas ao ambiente social onde uma pessoa vive, ao gênero, à cultura de um povo de modo geral. Dessa maneira, apenas a idade não dá conta de explicar o que é ser jovem.

Foi por ocasião do ano internacional da juventude, em 1985, que a Organização das Nações Unidas (ONU) utilizou um conceito de juventude alicerçado nas faixas etárias.

\footnotetext{
A escolha baseou-se em critérios apropriados que coincidem com importantes períodos de transição no ciclo da vida. A idade de 15 anos foi considerada como o início do período reprodutivo e os 24 anos podem ser considerados como a idade em que normalmente o jovem conclui o ciclo formal de educação e pode ingressar no mercado de trabalho (SABÓIA, 2010, p. 42-43).
}

Se for levado em consideração que em países como o Brasil, por exemplo, diversos fatores sociais, econômicos, entre outros, interferem na questão da reprodução e da escolarização, argumentos que defendam a definição etária com base nesses dados podem ser facilmente questionados. Quanto à idade para a reprodução, de fato, as pesquisas demográficas apontam para uma porcentagem considerável da população feminina que se enquadra na faixa etária em que os jovens estão compreendidos. Um problema que pode surgir dessa delimitação por idade é que muitos estudiosos desse tema apontam para uma diferença entre quem é o jovem e quem é o adolescente, distinguindo esses dois termos. Nesse sentido, esses conceitos vão se tornando cada vez mais específicos, então alguns dados demográficos produzidos podem não esclarecer de que população se está falando afinal. 
Nota-se, pela leitura dos dados demográficos recentes, que ter um filho quando se é ainda muito jovem é uma realidade para muitos brasileiros/brasileiras. Nos dados do Ministério da Saúde publicados no documento denominado Pesquisa Nacional de Demografia e Saúde da Criança e da Mulher (PNDS), publicada em 2009, mostra uma grande taxa de mulheres entre a faixa etária de 15 a 19 anos que estavam grávidas ou haviam estado grávidas ao menos uma vez.

É importante perceber no texto produzido por encomenda do governo brasileiro que a faixa etária entre 15 e 19 anos compreende adolescentes e não jovens. A mistura desses dois termos pode causar algumas confusões. Provavelmente por isso as pessoas que estudam temas ligados à adolescência e à juventude tenham procurado trilhar um caminho que leva a uma especificação cada vez maior desses dois termos a fim de tornar claro o público ao qual deve ser dirigida determinada política, sem que se corra o risco de deixar algum recorte etário fora dos programas e investimentos.

No que se refere ao uso do término da educação formal e o ingresso no mercado de trabalho como marco para a entrada na vida adulta, também existem alguns questionamentos a serem feitos, pois muitas vezes as pessoas demoram mais tempo para ingressar no ensino superior, para cursar as etapas e para concluí--las. Quanto ao trabalho formal, muitas pessoas não conseguem, mesmo após muitos anos de estudo, fazer parte dessa realidade. Juarez Dayrell et al. (2009, p. 93), ao elaborar um estado da arte sobre juventude e educação e mencionar o sucesso/fracasso escolar, afirma que

\begin{abstract}
A partir dos anos 80 e 90 assistimos a uma gradativa universalização do acesso, com uma diminuição sensível das taxas da população não escolarizada [...] No entanto, os índices apontam a persistência das desigualdades evidenciadas no fenômeno da evasão e da repetência, no descompasso idade/série e principalmente no domínio de aprendizagens fundamentais, o que remete à baixa qualidade do ensino, principalmente no sistema público.
\end{abstract}

Muitos abandonam a escola e a ela só retornam quando já são adultos (ou não retornam mais). Podemos notar que o argumento utilizado para delimitar o fim da juventude tendo por base o ingresso na vida reprodutiva e o final dela coincidindo com término da educação escolar/ingresso no mercado de trabalho formal também se mostra passível de muitas variações e incertezas. 
Se cursar a educação formal nos prazos pré-fixados entre os seis e os dezessete anos (do primeiro ano do Ensino Fundamental até o terceiro ano do Ensino Médio) não é algo possível para muitos estudantes brasileiros, conseguir um emprego ao fim desse período é também difícil e incerto. Quando são utilizados argumentos que relacionam a escolarização com a conquista de um emprego, as controvérsias são ainda maiores, pois

É verdade que os jovens de hoje estão muito mais escolarizados que há poucas décadas. No entanto, enfatizar muito a escolaridade é pressupor que existam empregos disponíveis para os escolarizados. Há muitos jovens, hoje, cujas possibilidades de inserção no mercado de trabalho não são condizentes com os anos de estudo (NOVAES, 2006, p. 108).

Desse modo, qualquer argumento que procure identificar quem são os jovens ou o que é a juventude deve ser utilizado com bastante cautela. Os dados demográficos ajudam a evidenciar uma série de questões, mas pode esconder tantas outras, que ficarão visíveis apenas com outras formas de abordagem. Os exemplos acima mencionados, a saber, da vida reprodutiva, da escolarização e do ingresso no mercado de trabalho como marcos definidores de quando começa e termina a juventude oferecem a oportunidade de compreender os limites que podem ter quaisquer argumentos que se utilize para esse fim.

Outras tantas possibilidades de conceituação da juventude poderiam ser mencionadas, bem como as contestações teóricas ou factuais possíveis que estabeleceriam um limite de análise. Esse, na verdade, é o caminho comum por onde passam os conceitos que estão relacionados com a interpretação das sociedades e dos grupos que as compõem. Qualquer tentativa de generalização ou de fechamento em torno da ideia de um conceito é passível de ser contestada.

No que se refere ao conceito de juventude, os debates estão longe de promover consensos. Provavelmente esse nem seja um dos objetivos de quem discute sobre esse tema. Os pesquisadores, pelo que pode ser observado da produção científica que tem o jovem como objeto, têm-se dedicado ao aprofundamento de suas teorias e tentado afirmar seu viés de análise. Nota-se um esforço em responder quem é o jovem e qual a importância social desse grupo.

Nas palavras de Groppo (2000, p. 11), "seria a juventude um componente realmente importante, de peso na formação e funcionamento das sociedades modernas?". O autor reconhece a importância da juventude nesse sentido e ressalta que a compreensão do que seja 
a juventude modernamente está vinculada à questão da "cronologização do curso da vida" que ocorreu por causa das "instituições modernas do século XIX e XX” (Ibidem, p. 12).

A ideia de juventude relacionada a faixas etárias surgiu dessa noção ainda mais antiga, a das "idades da vida", que, segundo Peralva (2007), cristalizou-se no século XIX, justamente quando se delineavam as mudanças sociais provocadas pela industrialização de muitos países na Europa. Sobre as "idades da vida", a autora ressalta que "embora ancoradas no desenvolvimento biopsíquico dos indivíduos, não são fenômeno puramente natural, mas social e histórico, datado e portanto e inseparável do lento processo de constituição da modernidade" (2007, p. 13).

Quando menciona a modernidade, a Peralva remete às "transformações ocorridas no âmbito da família" (2007, p. 15), que permitiram delinear mais claramente a noção de infância e revelar o lugar ocupado pela criança, conforme havia ressaltado Philippe Ariès ${ }^{2}$. A noção de que a vida se divide em idades certamente foi uma importante base para o desenvolvimento das teorias contemporâneas que delimitam a juventude pela questão etária.

Por muito tempo, o desenvolvimento do organismo - desde a infância até a velhice permearam os estudos sobre juventude. Nesse sentido, é preciso mencionar que

$\mathrm{Na}$ verdade, foram as ciências médicas e a psicologia, manipulando esses conceitos, que primeiro legitimaram cientificamente a concepção dessa fase que cria o indivíduo adulto. Assim, as concepções mais estritas sobre a juventude, advindas do século XIX e mantidas no presente século, procuram determinar biologicamente cada estágio da evolução do indivíduo e, portanto, também os momentos que correspondem à juventude (GROPPO, 2000, p. 271).

Essas ideias serviram e ainda servem de base para muitos estudiosos que se debruçam sobre os temas relacionados à juventude. Apesar de serem passíveis de questionamentos, os argumentos pautados pela delimitação etária das fases da vida continuam sendo mencionadas em estudos que querem destacar alguma delas: infância, adolescência, juventude, velhice (ou outras denominações que possam aparecer). É necessário ressaltar, de qualquer modo, que

A definição de juventude pode ser desenvolvida por uma série de pontos de partida: como uma faixa etária, um período da vida, um contingente populacional, uma categoria social, uma geração... Mas todas essas

\footnotetext{
${ }^{2}$ Angelina Peralva refere-se à obra de Philippe Ariès, de 1973, intitulada História social da criança e da família, na qual ele traz um capítulo denominado "as idades da vida". 
definições se vinculam, de algum modo, à dimensão de fase do ciclo vital entre a infância e a maturidade. Há, portanto, uma correspondência com a faixa de idade, mesmo que os limites etários não possam ser definidos rigidamente; é a partir dessa dimensão também que ganha sentido a proposição de um recorte de referências etárias no conjunto da população, para análises demográficas (ABRAMO E LEÓN, 2004, p. 6).

Dessa maneira, compreende-se que existe uma razão de ser para a delimitação etária da juventude. Por mais controversa que possa ser, ela está presente nas mais variadas óticas de análise do grupo social ao qual os jovens pertencem. E dadas às imprecisões que podem estar presentes quando se adota esse critério para estabelecer quem são os jovens, inclusive diferenciando-os dos adolescentes, cresceu o volume de estudos que procuram trabalhar com esse conceito, ressaltando-lhe características que são capazes de torná-lo cada vez mais específico.

Um dos caminhos foi justamente o de diferenciar juventude e adolescência, outro foi mencionar juventudes, assim no plural, para dizer que os jovens são diversos e heterogêneos, bem como o são também as possibilidades de olhares sobre esse tema. Há, porém, outro caminho: o dos que preferem partir do entendimento de que juventude é uma categoria social e, mais recentemente, uma trajetória.

No que diz respeito à compreensão da juventude e adolescência como designadores de faixas etárias, vale ressalvar que são dois termos que muitas vezes aparecem como sinônimos. Recentemente, no entanto, há esse esforço no sentido de retomar as discussões que procuram esclarecer do que trata cada um deles. São palavras diferentes que querem designar características distintas de pelo menos duas fases do período da vida que vai do final da infância até a maturidade. Essa diferença nos dois termos está relacionada ao modo como alguns campos do saber se relacionam com eles.

\footnotetext{
Normalmente, quando psicólogos vão descrever ou fazer referências aos processos que marcam esta fase da vida (a puberdade, as oscilações emocionais, as características comportamentais que são desencadeadas pelas mudanças de status etc.) usam o termo adolescência. Quando sociólogos, demógrafos e historiadores se referem à categoria social, como segmento da população, como geração no contexto histórico, ou como atores no espaço público, o termo mais usado é juventude (ABRAMO E LEÓN, 2004, p. 7).
}

Esse movimento intelectual que esmiúça as palavras pode levar pelo menos a duas direções: uma delas é a de delimitar os contornos e os limites que um conceito pode alcançar, diferenciando-o de outros; e a outra é a de aumentar a abrangência de situações que podem ser 
analisadas à luz de cada um desses conceitos. É um movimento de retração e expansão ao mesmo tempo. No que diz respeito aos termos juventude e adolescência, no Brasil, há uma relação desse movimento com a implementação de políticas públicas para os grupos de pessoas que se enquadram na condição de jovem ou adolescente.

\begin{abstract}
Atualmente, uma das tendências, no interior do debate sobre políticas públicas, é distinguir como dois momentos do período de vida amplamente denominado juventude, sendo que a adolescência corresponde à primeira fase (tomando como referência a faixa etária que vai dos 12 aos 17 anos, como estabelecido pelo ECA), caracterizada principalmente pelas mudanças que marcam esta fase como um período específico de desenvolvimento, de preparação para uma inserção futura; e juventude (ao que alguns agregam o qualificativo propriamente dito, ou então denominam como jovens adultos, ou ainda pós adolescência) para se referir à fase posterior, de construção de trajetórias de entrada na vida social (Ibidem, p. 8).
\end{abstract}

É possível notar o esforço que tem sido feito para deixar claro quais são os sujeitos compreendidos nessas duas palavras, de modo que nenhum grupo esteja excluído da possibilidade de estabelecimento de direitos e realização de ações que lhes garantam melhorias sociais. Se o foco estiver na adolescência, levando-se em consideração que, para o âmbito das políticas públicas, os limites etários são emprestados de organismos como a Organização Mundial de Saúde (OMC), a Organização das Nações Unidas (ONU) ou o Instituto Brasileiro de Geografia e Estatística (IBGE) e os documentos que tratam dos direitos de adolescentes como o Estatuto da Criança e do Adolescente (ECA), os brasileiros que estiverem entre os 17 e os 24 anos estarão fora da briga por melhores condições sociais.

Desse ponto de vista, mostra-se primordial a necessidade de evidenciar de quem se está falando quando se usa os termos juventude e adolescência. Até a década de 1990, os adolescentes eram alvo principal dos debates para implementar políticas públicas no Brasil. Daí para frente o debate sobre a condição juvenil reacendeu, tendo em vista a urgência de ações governamentais, sobretudo no que diz respeito ao trabalho e à violência no país (Abramo e León, 2004).

É possível compreender, diante de todas as possibilidades de vieses e análises e da multiplicidade de elementos que envolvem a juventude como campo de pesquisa, o porquê do uso desse termo no plural. Justamente por causa dessa diversidade de possibilidades de estudo, que revela um espaço no qual se desenrolam grandes disputas, é que se fala em “juventudes", pois 
Existem muitos e diversos grupos juvenis, com características particulares e específicas, que sofrem influências multiculturais e que, de certa forma, são globalizados. Portanto, não há uma cultura juvenil unitária, um bloco monolítico, homogêneo, senão culturas juvenis, com pontos convergentes e divergentes, com pensamentos e ações comuns, mas que são, muitas vezes, completamente contraditórias entre si (ESTEVES E ABRAMOVAY, 2007, p. 25).

Essas perspectivas de diversidade e heterogeneidade perpassam os trabalhos que se debruçaram sob o estudo das juventudes nas últimas décadas. Caminhou-se do olhar sobre o que as juventudes tinham em comum e o que as qualificava como grupo e categoria social para o que elas têm de singular, particular, único, levando-se em consideração o que os próprios jovens têm a dizer sobre si.

No que se refere à análise da juventude como trajetória, levam-se em consideração as transformações pelas quais o mundo vem passando nas últimas décadas, muitas delas relacionadas à tecnologia, e também às mudanças no modelo de passagem da infância para a vida adulta, o qual não é mais visto como uma linha reta que tinha um final bastante previsível (LEÓN, 2005).

É possível compreender que não se pode mais falar em uma padronização nas trajetórias da juventude ou da certeza do seu ingresso para a vida adulta após o término da educação básica, com a entrada no universo do trabalho formal, por exemplo. As trajetórias da juventude são tão diversas quanto também os são os jovens. E são múltiplas e diferentes as maneiras com que cada jovem, ou grupos de jovens, ingressa para a vida adulta.

É necessário destacar que as juventudes, do ponto de vista das pesquisas mais recentes, são muitas, heterogêneas, e apenas uma definição etária não dá conta de explicar o universo juvenil na contemporaneidade. Os jovens também não podem ser definidos somente por aspectos biológicos ou psicológicos ou englobados em grupos considerados homogêneos sem que se levem em consideração as questões particulares de cada pessoa.

Todo esse universo de possibilidades analíticas que se abre ao colocar o jovem como ser singular, como também o são os adultos e as crianças, acaba por abrir espaço para os mais diversos tipos de trabalho que se dedicam à juventude. São tantos caminhos possíveis que, nas pesquisas mais recentes, nota-se certa falta de aprofundamento e fragmentação. 
Por um lado, percebe-se a existência de pesquisas que observam o jovem como grupo e categoria social, ressaltando aspectos que sejam comuns ao grupo. Como exemplo, têm-se os estudos demográficos que, ao trabalhar com dados referentes à juventude como educação, criminalidade, uso de drogas, entre outros, não colocam em foco a trajetória de cada jovem, mas as características que podem ser aplicadas para um recorte amplo dessa população. Por outro lado, pode ser percebido o esforço daqueles que têm o jovem como um ser singular, até mesmo quando é observado dentro de um grupo, como as pesquisas que investigam grupos de hip hop, de punks, entre outros. Esse posicionamento depende do modo como se observa a juventude: como uma coletividade ou como sujeitos de uma trajetória que não coincide com a de outros. Trata-se de perspectivas de análise bem distintas, de escolha do que se quer investigar ou destacar.

É possível observar que esse movimento desenhado no universo de estudo da juventude ancora-se no desenvolvimento interno das ciências que se dedicam a esse tema e também nos processos de transformação social pelos quais a humanidade tem passado, sobretudo nos séculos XX e XXI, nos quais o tempo parece ter acelerado, tamanhas são as diferenças com relação a séculos anteriores e a rapidez com que as mudanças acontecem.

Juventude, ou juventudes, trata-se de um termo que, como muitos outros, não pode estar fechado, que provocou debates intensos em diferentes campos do saber e que passou por diferentes processos que o tornou ora mais abrangente, ora mais restritivo, e que ainda é alvo de muitas disputas.

No Brasil também há uma produção sobre juventude que cresce a cada dia. A grande quantidade de jovens e a pressão por políticas públicas voltadas para esse grupo social explica, em grande medida, esse interesse do pesquisador brasileiro pela juventude. Resta saber o que o pesquisador brasileiro tem escrito sobre esse tema.

\subsection{A juventude sob o olhar do pesquisador brasileiro}

No Brasil as obras que se dedicam à juventude concentram-se basicamente em dois períodos: os trabalhos que destacam o papel dos jovens durante o regime militar que se instalou no Brasil em 1964, mantendo-se até a década de 1980, como também os que passaram a ser produzidos a partir da década de 1990, tendo em vista o grande contingente populacional de jovens no país. Esse interesse pelos jovens em períodos específicos 
demonstra uma relação entre contextos sociais e históricos do país com a produção acadêmica referente a esse tema.

É possível notar que a conjuntura histórica, as transformações sociais e a emergência de novos paradigmas no âmbito das ciências que procuram compreender a dinâmica das comunidades humanas interferem no modo como se tem estudado a juventude. Essa constatação não é diferente para a realidade brasileira. De qualquer modo, mesmo encontrando algumas informações no sentido de situar no tempo o interesse pela juventude e relacioná-la com a conjuntura histórico-social e intelectual, ainda é uma tarefa difícil encontrar textos que sistematizem as ideias a esse respeito.

Dentro desse contexto, visualizou-se o desafio que é eleger o jovem como objeto de pesquisa, pois, além do fato de se tratar de um campo com possibilidades muito diversificadas de análise, há também a dificuldade em lidar com o conceito de juventude e em encontrar textos que refaçam o caminho científico percorrido por esse tema. Trabalhos que remetam às modificações dos olhares sobre os jovens como objeto de pesquisa na sociologia, na psicologia e na educação, por exemplo, e que permitam ao pesquisador compreender a dinâmica desses estudos, situando sua pesquisa dentro de tais debates, é algo ainda bastante incipiente.

Ao investigar a produção acadêmica brasileira nos programas de mestrado e doutorado sobre os jovens, entre os anos de 1999 e 2006, Sposito (2009, p. 32) chama a atenção para o fato de que esse ainda é um campo em construção e que há uma grande diversidade de recortes e tematizações que acabam por tornar "frágil" esse campo de estudos. Faz-se necessário que os estudos se condensem e busquem a consolidação que ainda falta para a produção acadêmica sobre juventude, já que a diversidade de olhares pode significar pouco aprofundamento, o que contribui para a mencionada fragilidade do campo de pesquisa que tem os jovens por objeto de investigação.

Uma das informações que mais se repete nos textos que procuram avançar os estudos sobre os jovens e que pode ser vista como um consenso é que a juventude como categoria trata-se de uma construção social, histórica, cultural e, portanto, não é um conceito que possa ser utilizado de modo universal. Partir desse pressuposto é o primeiro passo para não cair na tentação de fazer generalizações com relação às questões postas pelo universo juvenil, uma vez que 
Não existe uma concepção social única que caracterize e delimite o grupo geracional no qual os jovens estão inseridos, visto que se trata de uma categoria em permanente construção social e histórica. Assim, cabe falar em diferentes juventudes, que possuem a construção da identidade como questão central, mas que se destacam no imaginário social a partir de múltiplas referências da sociedade (DE SOUZA; DE PAIVA, 2012, p. 353-354).

Contudo, quanto à conceituação de juventude propriamente, nota-se que houve e ainda há intensos debates, que deixam transparecer a dificuldade em se chegar a um consenso, como acontece normalmente com qualquer tentativa de homogeneizar qualquer conceito. De acordo com Mauger (1994, p. 6 apud SPOSITO, 2001, p. 2), os problemas de definição do conceito de juventude fazem dele algo "epistemologicamente impreciso". E essa já é uma primeira dificuldade a ser enfrentada, a de definir do que ou de quem se está falando quando o assunto é juventude.

Quais seriam os vieses pelos quais se enxergou a juventude nas diferentes áreas do saber ao longo do tempo? Que caminhos teriam sido percorridos por esse tema até chegar ao atual estado em diferentes contextos de estudo? As informações desse tipo estão dispersas em textos que abordam temas muito diferentes relacionados aos jovens. A tarefa de sistematizar tais informações ainda precisa ser feita de modo mais completo. Uma vez realizado esse trabalho, provavelmente se evitariam muitas imprecisões teóricas e seria lançada uma luz importante sobre a relação entre o objeto de pesquisa, o contexto em que ele foi e é analisado, bem como sobre a evolução intelectual nesse sentido.

De qualquer modo, é possível recorrer aos autores que se destacam no cenário nacional e tentar traçar, mesmo que em linhas breves e pouco aprofundadas, de onde os pesquisadores brasileiros que se debruçam sobre a juventude partem para falar do seu objeto de investigação. Nesse sentido, ressalta- se que

A concepção de juventude corrente na sociologia, e genericamente difundida como noção social, é profundamente baseada no conceito pelo qual a sociologia funcionalista a constituiu como categoria de análise: como momento de transição no ciclo da vida, da infância para a maturidade, que corresponde a um momento específico e dramático de socialização em que os indivíduos processam a sua integração e se tornam membros da sociedade, por meio da aquisição de elementos apropriados da "cultura" e da assunção de papéis adultos (ABRAMO, 2007, p. 79). 
Muitos trabalhos produzidos sob essa perspectiva sociológica funcionalista colocam o sujeito jovem como um problema, na medida em que a ele cabe a manutenção dos valores culturais na passagem de uma geração a outra. As questões relacionadas a criminalidade, violência e delinquência juvenil permearam por muito tempo em voga por causa dessa noção de juventude em que se relaciona a transição de uma geração a outra com a manutenção da ordem vigente. Desse modo, diferentes investigações dentro desse recorte teórico apontam para possíveis desvios no processo de socialização da juventude, que podem significar um "risco para a coesão social" (ibidem, p. 80).

Ao seguir a trilha do processo pelo qual se enquadra internacionalmente os jovens como objeto de investigação, observa-se que a presença dos jovens e suas ações estiveram por muito tempo associadas à ideia sociológica de desajustamento. Na década de 1950, então, falava-se em jovens "delinquentes", e a preocupação estava em conduzi-los a uma socialização que permitisse sua “integração normal e sadia à sociedade". Nas décadas de 1960 e 1970, por sua vez, a imagem dos jovens estava associada à mudança, à "transformação profunda" e à "revolução" (Ibidem, p. 80-82).

No campo da psicologia, a juventude costuma ser observada a partir das mudanças físicas e psíquicas que ocorrem no final da infância. Segundo León (2005, p. 7), muitos estudos partem dessa noção psicológica que enfatiza "a puberdade, as oscilações emocionais, as características comportamentais que são desencadeadas pelas mudanças de status etc.". Psicólogos e sociólogos costumam ter vieses diferentes de análise da juventude, contudo eles podem se influenciar mutuamente. Esse fato é percebido quando se observa que algumas noções da psicologia que enxergam a adolescência ${ }^{3}$ como uma fase de transformações bastante turbulentas, influenciou o olhar da sociologia interessada em tratar dos problemas relacionados ao caráter rebelde e desviante dos jovens, provocados em grande medida pelas mudanças no corpo e na mente das pessoas durante essa fase da vida.

Esses estudos sobre a juventude, sociológicos ou psicológicos serviram e ainda servem de base para os trabalhos brasileiros nesse campo. Aqui são destacados pelos menos dois

\footnotetext{
${ }^{3}$ Até bem recentemente não se costumava observar nos textos sobre adolescentes e jovens uma distinção mais clara sobre que pessoas estão enquadradas em cada um desses conceitos. A necessidade de políticas públicas específicas tem feito com que esses conceitos se tornem cada vez mais restritos, designando grupos de pessoas que se distinguem geralmente pelas faixas etárias. Sobre esse assunto, podem ser consultados os artigos de Helena Wendel Abramo e Oscar Dávila León, sob a organização de Maria Virgínia de Freitas, cujo título é Juventude e adolescência no Brasil: referências conceituais, publicado pela organização civil Ação Educativa no ano de 2005.
} 
desses períodos a fim de que possa ser traçado, em linhas gerais, esse movimento de interesse pelo tema da juventude no país.

Nos textos brasileiros que descrevem a juventude e seus movimentos no contexto do regime militar que se instalou no Brasil em 1964 e que durou mais de 20 anos, pode-se perceber certa correlação com o olhar que enfoca o jovem sob o aspecto de sua imaturidade, de seu não ajustamento às regras sociais. Um texto clássico para se adentrar nos estudos desse período é o de Otávio Ianni, intitulado $O$ jovem radical, no qual o autor traça, em linhas gerais, o que, no Brasil e na América Latina, impõe ao jovem que queira transformar a sociedade e romper com a postura das gerações passadas. $\mathrm{O}$ autor faz importantes observações sobre o papel das instituições sociais, que muitas vezes tolhem os direitos dos jovens a condições dignas de vida, de trabalho e até de expressão e que levam à reflexão sobre a importância da não aceitação e da luta pela mudança. Desse ponto de vista, o “comportamento divergente", o "desajustamento", é a base da transformação social, tarefa que, pelas características da juventude, seriam-lhe atribuídas (IANNI, 1968, p. 230).

Os acontecimentos que envolveram a juventude das décadas de 1960 e 1970 no Brasil fizeram parte de um contexto maior das diversas manifestações juvenis contra variadas formas de repressão às quais estavam submetidos. Internacionalmente, os movimentos juvenis se colocaram contra a ordem vigente. Nesse sentido,

O problema apareceu como sendo o de toda uma geração de jovens ameaçando a ordem social nos planos político, cultural e moral, por uma atitude crítica à ordem estabelecida e pelo desencadear de atos concretos em busca de uma transformação - movimentos estudantis e de oposição aos regimes autoritários, contra a tecnocracia e todas as formas de dominação, movimentos pacifistas, as proposições da contracultura, o movimento hippie (ABRAMO, 2007, p. 81).

Os trabalhos que se dedicaram à juventude nesse período, então, colocavam em foco a ação radical e revolucionária da juventude, seu inconformismo e seu não ajustamento na sociedade. Desse modo, é possível notar uma correlação com os estudos que veem o jovem como um problema para a continuidade social, mesmo que essa continuidade significasse a permanência no poder de líderes autoritários. Esse engajamento juvenil nas questões relativas ao regime militar no Brasil foi também o que deu visibilidade à juventude e fomentou os estudos nesse sentido. 
Mais tarde, nas produções sobre a juventude brasileira dos anos 60 e 70, os jovens foram vistos de uma maneira mais positiva por conta de sua militância e, quando comparados aos dos anos 80, estes foram considerados apáticos e incapazes de se posicionar ou lutar por mudanças. $\mathrm{O}$ individualismo prevalecia em detrimento dos interesses coletivos. A juventude das décadas anteriores aparecia então como um espelho daquilo que deveria mesmo ser o papel juvenil: uma força motora capaz de transformar a sociedade (Ibidem, p. 83).

Nos anos 90, a juventude reacendeu como assunto entre os pesquisadores brasileiros. Para Spósito (2009, p. 17), “o tema juventude alcançou maior visibilidade nos últimos quinze anos no Brasil como produto da intersecção de vários domínios da vida social e da ação de diferentes atores". Alguns dos principais fatores que contribuíram para tanto foram a quantidade significativa da população jovem no país, os problemas relacionados com esse contingente populacional e a necessidade de políticas públicas que fossem capazes de amenizar tais problemas.

A maior parte das informações sobre a população jovem no Brasil procede de estudos demográficos, que contam com uma definição de juventude baseada em recortes etários estabelecidos por organismos internacionais e por órgãos ligados ao governo no país. Nesse sentido, um estudo publicado em 2010, com a contribuição do Fundo de População das Nações Unidas (UNFPA) e do Governo Federal, intitulado A juventude brasileira no contexto atual e em cenário futuro, demonstra o crescimento da população jovem e aponta para a necessidade de políticas públicas que a contemple.

Sabóia (2010, p. 44) afirma que “em particular, analisando a evolução da população brasileira de 15 a 24 anos de idade nos últimos 10 anos, observa-se que em 1996 esse total era de 28,9 milhões de jovens ao passo que em 2006 já eram 34,7 milhões”. Essa grande quantidade de jovens certamente influenciou na movimentação social para a elaboração de políticas governamentais que contemplassem essa população. A produção de trabalhos que contemplam a juventude a partir de então, está muito vinculada a esse movimento no sentido de estabelecer direitos para os jovens e fazer com que eles sejam respeitados.

Novaes (2006, p. 253) informa que diversos agentes como "pesquisadores, organismos internacionais, movimentos sociais, gestores municipais e estaduais passaram a enfatizar aspectos singulares da experiência social dessa geração, identificando suas vulnerabilidades, demandas e potencialidades". Essa postura em grande medida se relaciona com questões 
latentes como criminalidade, adoecimento, precariedade da escolarização, desemprego, pobreza e marginalização, entre outras, que afetam de modo significativo a população de jovens no Brasil e em outros países em desenvolvimento.

Da década de 1990 em diante, nota-se uma abertura dos governos brasileiros para a discussão acerca da juventude, seus dilemas e suas necessidades. Segundo documento da Secretaria Nacional de Juventude, que integra a já mencionada obra A juventude brasileira no contexto atual e em cenário futuro, foram criados programas que buscam atender às necessidades dos jovens e espaços de discussão como a Conferência Nacional da juventude, realizada em 2008 em Brasília, além de terem sido realizadas modificações legais como a Emenda Constitucional 042/2008, que regulamenta os direitos dos jovens e deu origem ao recentemente sancionado Estatuto da Juventude ${ }^{4}$.

No sentido de compreender quais são os itens apontados como necessários em atendimento ao público jovem, a autora Regina Novaes (2006, p. 276-277) afirma que a Secretaria Nacional da juventude aponta os seguintes desafios:

1. Ampliar o acesso e a permanência na escola de qualidade;

2. Erradicar o analfabetismo entre os jovens;

3. Preparar para o mundo do trabalho;

4. Gerar trabalho e renda;

5. Promover vida segura e saudável;

6. Democratizar o acesso ao esporte, ao lazer, à cultura e à tecnologia da informação;

7. Melhorar as qualidades de vida dos jovens do meio rural e nas comunidades tradicionais;

8. Promover os direitos humanos e políticas afirmativas;

9. Estimular a cidadania e a participação social.

É possível identificar na produção intelectual sobre a juventude não apenas a problemática que pode envolver a condição juvenil, mas também as tentativas de ação no sentido de prevenir e combater os males que afetam essa parcela da população. Os problemas apontados não são uma exclusividade dos jovens, mas afetam os brasileiros de modo geral e estão relacionados principalmente com a ação governamental e a gestão dos recursos públicos. Um dos motivos que pode ter levado à relação dos estudos sobre juventude com as muitas fragilidades sociais brasileiras foi provavelmente o crescimento dessa população e as ideias de continuidade cultural e transformação social que estão ligadas a eles.

\footnotetext{
${ }^{4}$ O Estatuto do Jovem foi aprovado pelo Congresso Nacional no dia 5 de agosto de 2013 e já vigora no Brasil, conforme informado no site governamental Portal Brasil, acessado em 28 de fevereiro de 2014 às $20 \mathrm{~h} 53$. 
Muito há ainda por ser feito no sentido de tornar consistentes os estudos sobre juventude no país, diante de todo esse contexto que tem sido contemplado de diferentes maneiras pelos pesquisadores. Segundo Sposito (2009, p. 32), há "fragmentação", “dispersão da investigação", "ausência de agendas de pesquisa", que demonstram certa "fragilidade" nesse campo de pesquisa. Evidencia-se a necessidade de fomento no diálogo entre os trabalhos e o aprofundamento de questões que sejam recorrentes. Esses são os desafios que se esboçam para pesquisadores de temas relacionados à juventude na contemporaneidade.

No que toca à relação do jovem com a educação (em um sentido amplo do termo), há muitos estudos já produzidos e com abordagens bastante diversas. Este trabalho, nesse sentido, pretende contribuir para a compreensão dos processos educativos que ocorrem fora da escola, no ambiente da cultura e da vida comunitária. Para tanto, é preciso que se aprofunde o olhar sobre a juventude e os processos educativos nos quais ela está inserida, a fim de compreender o que se espera ao educar o jovem e o que ele espera de si mesmo nesse contexto.

\subsection{Juventude e práticas educativas}

O ser humano desenvolveu cedo a capacidade de passar seus conhecimentos às gerações futuras de modo a não perder aquilo que já havia sido descoberto e aprendido. Essa foi a base do desenvolvimento cultural humano. A educação fundamenta-se nessa ideia primordial de não deixar que o conhecimento se perca, de não permitir que os elementos culturais já postos se extingam.

A educação aqui é compreendida, então, como um fenômeno amplo que existe desde os primórdios da humanidade e que ocorre em diversos contextos, de maneira intencional ou não. Desde as formas mais rudimentares de transmissão do conhecimento até a institucionalização da educação, um longo caminho foi percorrido e muitas transformações ocorreram - que não fizeram desaparecer a transmissão oral e a aprendizagem por meio do exemplo. De acordo com Illich (1982, p. 88) "a maior parte da aprendizagem ocorre casualmente e, mesmo, a maior parte da aprendizagem intencional não é resultado de uma instrução programada". Não se pode desejar ou esperar que alguém aprenda algo pelo simples fato de que assim ficou determinado por quem quer que seja, um adulto ou a escola. 
Buber (1987) concorda com a ideia de Illich, exposta acima, no sentido de que deve haver espontaneidade no ato de se educar. Para aquele, "a espontaneidade é o fator preponderante na educação" (p. 90). Não há como forçar esse processo e esperar que os resultados desejados sejam alcançados tal como foram planejados. Em se tratando de educação, lidamos com liberdade e vontade.

As práticas educativas que buscamos reconhecer por meio deste trabalho são aquelas que Buber descreveu ao afirmar que "educação é relação" (1987, p. 93), uma relação com fim nela mesma. Essa educação é a que permite a uma pessoa reconhecer-se observando o seu próximo, mesmo em meio às exigências que o mundo impõe para a sobrevivência de cada um. Educar passa pela experiência de guardar aquilo que é comum a um grupo de pessoas, que estão juntos por se reconhecerem mutuamente como iguais. Trata-se do seu legado, algo que não deve ser perdido com o tempo.

Contudo, a preocupação que mais se pode notar entre os pesquisadores que se dedicam a estudar o jovem em sua relação com a educação é a de tentar indicar e solucionar os problemas referentes à escola. Provavelmente essa constatação vem do fato de que instituição escolar se tornou o centro para o qual convergem as ideias sobre educação. A escola é vista como algo indispensável, sem a qual se perderiam os conhecimentos, os valores e a própria cultura humana. Grande responsabilidade tem sido atribuída a essa instituição como se por meio dela fosse possível exterminar as desigualdades e equiparar as possibilidades de acesso aos bens culturais e ao mercado de trabalho.

Um rápido olhar sobre os estudos mais recentes nesse contexto permite construir e visualizar os contornos do pensamento que relaciona os jovens com a educação. Observa-se no já mencionado trabalho coordenado por Sposito (2009), no qual foi elaborado um Estado da Arte para o tema juventude, investigando-se a produção da pós-graduação (dissertações e teses) entre 1999-2006. De 188 trabalhos analisados dentro do recorte temático Juventude e Escola, 92\% haviam sido produzidos dentro da área de educação. Na pós-graduação em educação, portanto, a preocupação com os problemas relacionados com a escolarização são o foco principal (DAYRELL et al., 2009, p. 57). Do total de trabalhos analisados, ou seja, 1427, cerca de 13\%, pertence à categoria Juventude e Escola (SPOSITO, 2009, p. 23).

Esse é um dos estudos mais recentes e completos que se dedicam a levantar informações sobre a produção acadêmica a respeito da juventude. Por meio dele percebemos 
o grande interesse em pesquisar os jovens escolarizados, os problemas que decorrem dessa realidade e as ações possíveis para agir sobre tais problemas. Esse tipo de constatação, a qual chegaram Sposito (2009) e seus colaboradores, é reflexo da grande importância que se atribui contemporaneamente à instituição escolar.

A ideia de uma escola laica, pública (com a obrigatoriedade de oferta pelo Estado) e obrigatória, foi gestada no bojo do ideário iluminista que serviu de base para as chamadas revoluções burguesas. Foi posta em prática primeiramente na França e depois paulatinamente espalhou-se por todo o Ocidente.

É importante destacar que, naquela escola que nascera ainda no século XVIII, com a Revolução Francesa, o objetivo principal era alcançar a liberdade por meio da formação intelectual. Era também garantir, por meio da educação, a defesa da nacionalidade e da democracia. Esses objetivos se relacionavam fortemente com a ideia de que, por meio da educação e da nivelação das oportunidades de emancipação, o mérito pessoal e o talento seriam as únicas formas de manutenção das desigualdades (essas desigualdades eram consideradas naturais pelos iluministas, em oposição às desigualdades estamentais relacionadas com os títulos de nobreza e com as posses de uma pessoa).

O modelo de educação nascido nessa ocasião obviamente não permaneceu intocado ao longo dos séculos; ele sofreu alterações diversas, mas, de acordo com Vial (1970, p. 18-19 apud BOTO, 2003, p. 743), "a doutrina, naquilo que ela tem de essencial, permanece intacta",

Desse modo, aqueles ideais de emancipação, de equiparação de oportunidades, que podem ser traduzidos na ideia de que a universalização das escolas seria uma espécie de trampolim para alcançar a liberdade e a igualdade tão caras aos iluministas, tornaram-se um traço marcante da ideologia que circunda a educação escolar. Contudo essa ideologia não se concretizou tal como havia sido sonhada séculos antes. O sistema escolar, com todos os problemas que apresenta contemporaneamente, em países como o Brasil, aponta para a fragilidade desse depósito de confiança na escola.

\footnotetext{
5 Para saber mais sobre esse assunto, ver o artigo de Calota Boto Na Revolução Francesa, os princípios democráticos da escola pública, laica e gratuita: o relatório de Condorcet. Disponível em: <www.cedes.unicamp.br>. Acesso em: 5 de abril de 14 às 9h53. 
Nas décadas de 1960 e 1970, tendo em vista todos os problemas relacionados à educação escolarizada, momento em que se reconheceu uma crise ${ }^{6}$ nesse setor, os olhares se voltaram para a educação em outros ambientes, como o da cultura. Isso aconteceu muito em virtude do apoio que essas outras formas educativas poderiam dar àquela primeira. As investigações então passaram a ser realizadas no sentido de esclarecer as diferenças entre a educação formal, a não formal e a informal.

Por educação formal entende-se o tipo de educação organizada com uma determinada sequência e proporcionada pelas escolas enquanto que a designação informal abrange todas as possibilidades educativas no decurso da vida do indivíduo, constituindo um processo permanente e não organizado. Por último, a educação não formal, embora obedeça também a uma estrutura e a uma organização (distinta, porém das escolas) e possa levar a uma certificação (mesmo que não seja essa a finalidade), diverge ainda da educação formal no que respeita à não fixação de tempos e locais e à flexibilidade na adaptação dos conteúdos (AFONSO, 1989, p. 78 apud PEREIRA, 2011, p. 77).

No sentido de compreender de onde vem a conceituação das diferentes formas educativas supracitadas, é necessário adentrar nos estudos que deram origem a interpretações como essas. No trabalho de Hernandez (2000, p. 122), a educação não formal é apresentada como "a terceira ramificação no campo da Pedagogia Social, situada entre a Pedagogia Comunitária e a Educação Popular”. Essas ramificações fazem, de acordo com a autora, parte de um campo maior, o da Ciência e da Educação.

Ao citar Cabanas (1994), a autora menciona que o campo da Pedagogia Social, do qual deriva o termo educação não formal, é fruto do século XIX, com o uso do termo por Paul Nartop (1898). Posteriormente, em 1932, Nohl e Pallat (apud HERNANDEZ, 2000, p. 125) desenvolveram uma enciclopédia dedicada ao tema, o que possibilitou então o estabelecimento desse campo do conhecimento como uma teoria. Atualmente a Pedagogia Social está, segundo esses autores (Nohl e Pallat), voltada para questões ligadas à cidadania.

\footnotetext{
${ }^{6}$ De acordo com Pereira (2011, p. 78), a publicação do livro de P. H. Coombs em 1968 e sua republicação em anos seguintes com o título A crise mundial da educação. Perspectivas mundiais é considerado um marco no que se refere à fala aberta sobre os problemas da educação e a proposição da valorização de outras formas educativas. Nesse sentido, entrou em discussão o reconhecimento das educações informal e não formal como contribuintes importantes do processo educativo. Hernandez (2000, p. 126) salienta que esse trabalho de Coombs foi fruto de uma conferência sobre a crise na educação promovida pela UNESCO, na Virgínia, Estados Unidos, no ano de 1968.
} 
Tais estudos da Pedagogia Social serviram de base para as discussões que fomentaram os trabalhos das décadas de 1960 e 1970 que tratavam da crise da educação escolar e propunham a valorização de outras formas educativas como auxiliares ou complementares da educação formal. Esse movimento chegou ao Brasil na década de 1980, e os conceitos de educação não formal e informal passaram a fazer parte do vocabulário dos profissionais da educação escolar. Os órgãos do governo brasileiro ligados à educação passaram então a fomentar o debate sobre tais conceitos a fim de incorporar práticas não formais ao ambiente da escola.

É possível tirar algumas conclusões das discussões internacionais e nacionais a respeito da crise da educação formal e da incorporação de práticas educativas não formais e informais. Primeiramente existe uma dificuldade no sentido de dizer o que na verdade engloba a educação não formal e, como consequência disso, chamam diferentes práticas educativas por esse nome. Depois, essa forma de educação aparece muitas vezes como uma negação da educação escolar, ou seja, não formal em oposição a formal, apesar de diferentes autores trabalharem com essa forma educativa como complementar àquela que acontece na escola. Nota-se, nesse contexto, uma tentativa de solucionar problemas de uma educação escolar descontextualizada e pouco eficiente, levando para dentro dela práticas educativas cotidianas nas quais percebem a essência do que é educar.

Com relação às práticas educativas que estão abarcadas no conceito de educação não formal, podem ser citados alguns exemplos a fim de que seja possível demonstrar a sua diversidade. Ghon $(1999$, p. 7) afirma sobre a educação não formal que

Ela aborda processos educativos que ocorrem fora das escolas, em processos organizados da sociedade, ao redor de atividades coletivas do chamado Terceiro Setor da sociedade, abrangendo movimentos sociais, organizações não governamentais e outras entidades sem fins lucrativos que atuam na área social; ou processos educacionais, frutos da articulação das escolas com a comunidade educativa, via conselhos, colegiados etc.

No texto da autora, já se pode notar um universo de possibilidades de enquadramento do que seria o não formal em termos de educação não formal, incluindo espaços ligados à escola. Nassif (s/d, p. 70, apud HERNANDES, 2000, p. 130-131) afirma sobre a educação não formal que 
La educación no formal es la que generalmente se da fuera del marco de las instituiciones educativas especializadas para porveer aprendizaje a subgrupos particulares de la población [...] el marco de referencia de la educación no formal es, prácticamente, toda la actividad social [...] todas las demás formas de aprendizaje que se dán en la sociedade, fuera de instituciones educativas especializadas.

Na resenha de Osmar Fávero (2007) para o livro organizado por Margareth Brandini Park e Renata Sieiro Fernandes, intitulado Educação não formal: contextos percursos e sujeitos, ele salienta que, além da procura por conceituar o que seja a educação não formal, os autores

[...] analisam ações de complementação à inclusão de crianças com necessidades especiais no sistema escolar; ao trabalho com crianças de rua, discutindo inclusive a singularidade do "educador de rua"; o trabalho com adolescentes e jovens infratores, em abrigos ou centros de convivência; atividades de lazer e arte, realizadas em oficinas de criatividade; o papel da comunicação para a inclusão social; a importância da organização de grupos que resgatem "memórias culturais urbanas" (hip hop, grafite etc.) ou recriem capoeira, roda de samba e samba de roda; esporte e educação física; importância dos museus de arte etc. (FÁVERO, 2007, p. 616).

O objetivo, ao mencionar os exemplos acima, foi demonstrar que diferentes tipos de ação educativa que ocorrem fora de ambientes escolares e que tenham uma intencionalidade podem ser classificados dentro do contexto não formal. A bibliografia que fomenta os estudos nessa área deixa uma grande abertura para o enquadramento de diferentes tipos de práticas. Os trabalhos mais recentes feitos sob a ótica dessa corrente de pensamento aproximam os dois tipos de educação, formal e não formal, colocando essa última como uma espécie de auxiliar ou complementar da primeira.

A premissa que se defende aqui é de que eles são processos educativos distintos. Muito antes de eles existirem, escolas organizavam seus modos de educar os mais jovens, inclusive ensinando-lhes profissões ${ }^{7}$. Compreender como se desenvolveu a ideia de educação não formal no país e tentar procurar os elementos que são apontados pelos pesquisadores como essenciais nessa forma educativa permitirá investigar, sob esse ponto de vista, a educação que ocorre no ambiente de realização da congada. Pessoas de diferentes faixas etárias se reúnem para aprender as músicas, os passos, o sentido religioso, entre outros temas relacionados a essa manifestação cultural, que faz parte do cotidiano da comunidade na qual

\footnotetext{
${ }^{7}$ Sobre o surgimento da escola na Idade Média Ocidental e sobre a educação das pessoas mais jovens para o convívio social e para as profissões, ver Philippe Ariès em História social da criança e da família, primeira edição brasileira em 1978 pela LTC - Livros Técnicos e Científicos - Editora S.A, Rio de Janeiro. 
se inserem os jovens, que são o principal objeto de investigação do presente trabalho. Um interessante ponto de partida é compreender o contexto em que desenvolveram os estudos e o desenho do campo da educação não formal no país.

No Brasil, as ideias sobre a educação não formal ganharam força ainda nas décadas de 1960 e 1970, quando se discutia no país acerca da educação popular nas perspectivas de Paulo Freire e da pedagogia da libertação. Essas correntes de pensamento estavam vinculadas, por um lado, à necessidade de alfabetização e conscientização contidas nas ideias de Freire e, por outro, às organizações dos movimentos sociais das comunidades brasileiras, muitas delas ligadas à Igreja Católica. $\mathrm{O}$ desenvolvimento dessas ideias ocorreu em meio ao estabelecimento de um regime militar no país, que durou cerca de vinte anos ${ }^{8}$.

Já na década de 1980, o tema reacendeu, e a educação não formal, bem como a informal, entraram na pauta de discussões novamente. A perspectiva era de alocar as experiências sociais cotidianas em favor da educação escolarizada. Por parte dos órgãos de educação ligados ao governo, procuravam estabelecer a ideia de que conferir uma organicidade à educação não formal, estabelecendo para ela uma pedagogia própria, permitiria fazer dela um instrumento de emancipação social (CONTRERAS, 1983). Essas ideias vinham no bojo das discussões e ações no sentido de colocar a educação não formal como uma espécie de redentora da educação, tendo em vista que a educação escolar havia fracassado em sua tarefa. Todas as discussões acerca da educação que se dá na escola ou em outros ambientes, diferenciando-as, mostraram-se ineficazes. Não se tratava e ainda não se trata de caracterizar ou nomear de diferentes maneiras o que ocorre no ambiente escolar ou fora dele; ou se o que se ensina está organizado de maneira intencional ou ocorre ocasionalmente. Não é aí que se encontra a solução para os problemas que enfrenta a educação escolarizada. Tais problemas são de outra natureza.

Há uma diferença latente entre ser educado dentro de uma perspectiva comunitária, em um ambiente no qual há uma vivência que dá significado singular aos conhecimentos ali presentes, e na escola, cujas características educativas são homogeneizantes e padronizadoras, onde há uma imposição de conteúdos hierarquizados e muitas vezes vazios de sentidos aos estudantes (TUNES; PEDROZA, 2011). Foi por causa da percepção desse contraste que

\footnotetext{
${ }^{8}$ Um aprofundamento sobre esse tema é possível por meio da obra de Demerval Savianni, História das ideias pedagógicas no Brasil. Campinas: Autores Associados, 2007. 
pareceu bastante significativa a ideia de investigar a dinâmica do processo educativo em uma manifestação cultural.

Existe um esforço por parte dos investigadores que se dedicam ao estudo da educação escolarizada em encontrar soluções possíveis para os problemas que estão expostos a quem quiser vê-los. As muitas produções acadêmicas que fazem levantamentos das dificuldades enfrentadas na escola ou as que se fiam nas correntes pedagógicas contemporâneas interessadas em encontrar caminhos e soluções, contudo, trazem apontamentos que não resolveram definitivamente a questão. A própria estrutura da escola, com suas amarras - que vão desde o controle exercido pelo Estado até os pormenores relacionados à vontade de ensinar e aprender verdadeiramente -, impede que o conhecimento produzido na tentativa de encontrar novos caminhos consiga de fato trazer alguma transformação realmente significativa.

Nessas tentativas de sanar as dificuldades ligadas à escolarização, a atenção ora direcionou-se para os professores, ora para os estudantes, procurando um possível culpado para o fracasso desse modelo de educação. Ao colocar os estudantes como o foco do problema, são criadas categorias para enquadrar os alunos (os que se adaptam e os que não se adaptam, por exemplo), bem como uma série de patologias que podem explicar por que muitos não se enquadram no padrão estabelecido. Se ainda assim os entraves não são superados, o olhar se volta para o professor, que, nessa perspectiva, é visto como despreparado para fazer o que deve fazer: ensinar de modo que todos os estudantes sobre sua responsabilidade obtenha sucesso. Essa é uma realidade perversa, em que se procuram culpados para a falha em uma estrutura que, por ser conservadora, não é afetada em seu cerne por medidas paliativas (TUNES; PEDROZA, 2011).

Uma questão central é que a aprendizagem dentro do processo educativo nunca é igual para pessoas diferentes (nem mesmo igual para a mesma pessoa em circunstâncias diferentes), então aí reside o problema da padronização imposta pela escola. É importante observar que dentro dessa estrutura conservadora não há como observar e atender a cada estudante dentro daquilo que ele tem de específico. Além disso, para se aprender algo, é necessário que haja liberdade e vontade. Liberdade no sentido de que há uma escolha e não uma imposição, de que existe a indicação de um caminho, mas não um passo a passo de como chegar até o final dele; vontade no sentido de que ninguém aprende aquilo que não lhe faça sentido ou de forma nenhuma lhe interesse, pois "no processo de educação o mestre deve ser os trilhos por onde se 
movimentam com liberdade e independência os vagões, que recebem dele apenas orientação do próprio movimento" (VIGOTSKI, 2010, p. 64).

Desse modo, é preciso enxergar a educação como um processo amplo que pode ocorrer em qualquer espaço. A dificuldade atual reside em que a sociedade brasileira se fia na ideia de que a escola é o espaço privilegiado onde a educação deve ocorrer. O que acontece fora do ambiente escolar pode até auxiliar, mas nunca será reconhecido como algo válido por si só, pela falta de um certificado expedido por uma instituição ligada ao Estado. Esse conjunto de fatores relacionados à educação escolarizada e seus problemas, por um lado, e o desprezo pelos processos educativos que ocorrem em outros ambientes (por não serem oficiais e passíveis de certificação formal), por outro, impede que se possam enxergar as reais possibilidades de se ensinar e aprender de outras maneiras e em outros contextos. E, desse modo, há sempre uma concentração de esforços em resolver os problemas da escola, e não da educação em um sentido holístico.

No âmbito da cultura, os processos educativos podem ser vistos sob outra perspectiva, na qual se pode observar a singularidade do aprender em cada pessoa, a importância dos laços formados entre quem ensina e quem aprende, o interesse e a vontade, fatores que estão desvinculados de avaliações e certificações, mas que são essenciais para a existência humana.

Voltemos então nosso olhar para a cultura a fim de entender como ela opera. Acreditamos que podem ser identificadas valiosas pistas sobre educação nesse contexto. Para tanto, é preciso que saibamos o que captar em se tratando de cultura. Nossa próxima etapa, então, será compreender de que modo devemos observar as pessoas em seu meio cultural, a fim de identificar os aspectos que possam responder aos objetivos aqui propostos. 


\section{CAPÍTULO II: A CULTURA COMO ESPAÇO DE INVESTIGAÇÃO}

Compreender as relações que os jovens estabelecem com as práticas educativas no contexto de uma manifestação cultural exige que saibamos como as pessoas interagem em seu ambiente cultural. O que observar a fim de identificar os modos de inserção de uma pessoa ou de um grupo de pessoas em uma cultura específica? Este capítulo traz algumas ideias a respeito da cultura como espaço de investigação e sobre a relação dos jovens com a cultura.

\subsection{Por que e como observar a cultura?}

A congada é uma das tantas festas da cultura brasileira que perduram no tempo, mas não sem as mudanças que são típicas dos fenômenos culturais. Desde o tempo em que as terras brasileiras foram ocupadas pelos portugueses e o trabalho escravo africano foi adotado, os elementos religiosos europeus e africanos associados à dança e à música fizeram-se presentes no cotidiano colonial. Desde então os elementos da congada foram sendo modificados de acordo com as características geracionais de cada época.

É preciso destacar que, nas últimas décadas, foi dado um grande impulso às investigações que partem da cultura para tratar de outros fenômenos sociais. Nesse sentido, 
Stuart Hall (1997) menciona que a cultura não tem sido mais vista como um acessório da vida social, mas como algo que a constitui - que é parte primordial da mesma. Dentro desse contexto, proliferaram-se os estudos que têm por base fenômenos culturais, quer sejam ligados à tradição ou a temas muito recorrentes na atualidade, como as mídias e as novas tecnologias da comunicação e da informação.

Ao mencionar a chamada "virada cultural", o autor acaba por salientar o papel de destaque que os pensadores têm dado à cultura em seus trabalhos.

\begin{abstract}
Nas ciências humanas e sociais, concedemos agora à cultura uma importância e um peso explicativo bem maior do que estávamos acostumados anteriormente - embora a mudança nos hábitos de pensar sempre seja um processo lento e desigual, e não sem poderosos ataques à retaguarda [...] Apesar disso, uma revolução conceitual de peso está ocorrendo nas ciências humanas e sociais. Isso vai muito além da aprendizagem que nos leva a pôr as questões culturais numa posição mais central, ao lado dos processos econômicos, das instituições sociais e da produção de bens, da riqueza e de serviços por mais importante que seja esta mudança. Refere-se a uma abordagem da análise social contemporânea que passou a ver a cultura como uma condição constitutiva da vida social, ao invés de uma variável dependente, provocando, assim, nos últimos anos, uma mudança de paradigma nas ciências sociais e nas humanidades que passou a ser conhecida como a "virada cultural" (HALL, 1997, p. 23).
\end{abstract}

O novo tratamento que é dado então à cultura, que a coloca como base para a investigação de outros temas, justifica a intenção aqui defendida de procurar, em uma manifestação cultural, os processos educativos que nela ocorrem.

Diversos recortes poderiam ser utilizados para guiar este trabalho, inclusive dentro da própria antropologia, já que neste campo do saber há diferentes posições com relação ao que seja cultura e aos modos de proceder em estudos que têm por base fenômenos culturais. No caminho traçado entre as leituras feitas no intuito de estabelecer parâmetros para esta investigação, surgiram conceitos utilizados por Clifford Geertz, a exemplo da noção lançada por ele de interpretação das culturas ${ }^{9}$.

Partir da ideia de que as culturas podem e devem ser interpretadas parece ser um caminho profícuo para este estudo, tendo em vista o que se pretende fazer: ouvir o que os jovens têm a dizer sobre si mesmos e sobre os processos educativos que ocorrem dentro da manifestação da congada da qual participam. De antemão, é possível imaginar todo um

\footnotetext{
${ }^{9}$ Termo retirado da obra Interpretação das culturas, publicada pela editora LTC em 1989.
} 
conjunto de informações que provavelmente farão muito sentido para eles e poderão causar estranhamento aos ouvidos de quem não pertence àquela realidade, daí a importância do conceito de interpretação das culturas.

É possível imaginar apenas com base em uma vaga noção da riqueza cultural brasileira a enorme quantidade de relações educativas que se desenrolam no âmbito das manifestações culturais, sem que com isso elas sejam consideradas como processo educativo em si, com significado próprio e com sentido para aqueles que se relacionam nesse contexto. As atividades culturais, tradicionais ou não, entram no universo da educação formal muitas vezes como mero acessório, não tendo valor por si mesmas, o que é lamentável.

O pensamento de Geertz sobre a investigação de eventos singulares em suas minúcias como ponto de partida para se chegar a uma compreensão mais complexa de realidades mais amplas, desse modo, mostra-se aqui como um norte para o presente trabalho. Contudo, este não é o único aspecto de seu trabalho que se harmoniza com o que está sendo proposto aqui. Ao definir cultura, o autor informa a seus leitores que ele a considera "não um complexo de comportamentos concretos, mas um conjunto de mecanismos de controle, planos, receitas, regras, instruções (a que os técnicos de computadores chamam de programa) para governar o comportamento" (GEERTZ apud LARAIA, 2009, p. 62).

Disso tratar-se-iam os esquemas culturais de cada sociedade, um conjunto de regras, de padrões, de comportamentos nos quais as pessoas estão imersas e dos quais elas compartilham. Essa talvez seja a chave para se compreender no comportamento e na fala das pessoas dentro de uma determinada realidade cultural aquilo que porventura elas não deixam entrever em sua fala e em suas ações.

Esse conjunto de fatores que configuram um sistema cultural não está explícito na mente de cada pessoa que vive em uma determinada sociedade.

Para Geertz, os símbolos e significados são partilhados pelos atores (os membros do sistema cultural) entre eles, mas não dentro deles. São públicos e não privados. Cada um de nós sabe o que fazer em determinadas situações, mas nem todos sabem prever o que fariam nessas situações. Estudar a cultura é portanto estudar um código de símbolos partilhados pelos membros dessa cultura (LARAIA, 2009, p. 62-63). 
Entender esses símbolos e significados públicos torna-se essencial para estudos que pretendem trabalhar com o âmbito da cultura. Eles nem sempre estão explícitos ou são compreendidos com facilidade por alguém que está de fora, ou seja, por alguém que não compartilha dessa mesma realidade cultural. É preciso que haja dedicação e esforço por parte do pesquisador e também uma sensibilidade no sentido de captar aquilo que está por trás, nas entrelinhas das ações e das falas.

É nesse sentido que Geertz afirma que compreender determinada cultura passa pela interpretação dela. Não se trata de um simples trabalho de observação e descrição, mas do que ele chama de "descrição densa" 11083, p. 4), ao se apropriar do conceito desenvolvido por Gilbert Ryle.

Para além de compreender do que se trata a cultura e de como proceder para investigála cientificamente sob um olhar antropológico, é preciso saber de que modo os seres humanos se relacionam com ela. É necessário ter em mente quais são as implicações de uma determinada realidade cultural para as pessoas que vivem em seu meio, bem como identificar as ações humanas que dinamizam a cultura. Estar a par dessas interfaces entre a cultura e a comunidade em que ela é gerada e constantemente reformulada mostra-se bastante relevante para observar qualquer aspecto daí decorrente, como é o caso do estudo aqui proposto, a saber, o de investigar os processos educativos que ocorrem no âmbito de uma manifestação cultural.

Um dos primeiros passos para se compreender como essas relações podem estar postas é identificar a ação da cultura sobre a visão de mundo das pessoas. Em lugares distintos, com diferentes traços culturais, as pessoas terão comportamentos, ações, modos de ser e de fazer muito singulares. É possível afirma que

O modo de ver o mundo, as apreciações de ordem moral e valorativa, os diferentes comportamentos sociais e mesmo as posturas corporais são assim produtos de uma herança cultural, ou seja, o resultado da operação de uma determinada cultura (LARAIA, 2009, p. 68).

Os valores culturais se fazem presentes governando o comportamento humano, dando as diretrizes do que pode e do que não pode ser feito, do que é considerado válido ou

\footnotetext{
${ }^{10}$ Geertz apropria-se do conceito de "descrição densa", de Gilbert Ryle, para defender como deve ser orientada a prática etnográfica no campo da antropologia. Para Geertz, a descrição densa trata-se de algo mais complexo do que simplesmente observar e descrever algum fenômeno cultural. 
desprezível aos olhos de uma determinada sociedade ou comunidade humana. É importante levar em consideração que aquilo que está explícito na fala e no agir das pessoas passa por esse campo de restrições imposto pela cultura e que nem tudo o que se ouve é de fato o que se observa na prática. Dentro dessa perspectiva, torna-se bastante válida a recomendação de Geertz sobre a necessidade de uma observação minuciosa e uma descrição densa de qualquer fenômeno cultural eleito como objeto de estudo.

Outro aspecto relevante a ser considerado é o modo como as pessoas participam da cultura na qual estão imersas uma vez que,

a participação de cada pessoa em sua cultura é sempre limitada; nenhuma pessoa participa de todos os elementos de sua cultura. Este fato é tão verdadeiro nas sociedades complexas com um alto grau de especialização, quanto nas simples, onde a especialização refere-se apenas às determinadas pelas diferenças de sexo e de idade (LARAIA, 2009, p. 80).

Uma mesma pessoa provavelmente não conseguirá partilhar de todos os aspectos da cultura que caracteriza a comunidade da qual faz parte. Do mesmo modo, pessoas diferentes podem partilhar da mesma característica de sua cultura, mas vivenciar tal aspecto de maneiras muito diferentes. É preciso ter em mente as armadilhas que podem surgir das tentativas de generalização quando se trata da experiência cultural de cada ser humano. Nesse sentido, fazse necessário levar em consideração essas filigranas analíticas em se tratando de assuntos relacionados à cultura - sobretudo quando a análise se pautar na fala das pessoas imersas nos fenômenos culturais.

Além disso, cada ambiente cultural tem sua própria lógica e muitas vezes o investigador que não pertence àquele meio considera ilógico ou estranho o que está observando, correndo o risco de emitir juízos de valor ou de não enxergar de fato o que está posto concretamente por uma determinada comunidade em termos culturais. Ao se propor um trabalho que envolva análises no âmbito da cultura, é preciso ter em mente a seguinte afirmação:

Que todas as sociedades humanas dispõem de um sistema de classificação para o mundo natural parece não ter mais dúvida, mas é importante reafirmar que esses sistemas divergem entre si porque a natureza não tem meios de determinar ao homem um só tipo taxionômico (LARAIA, 2009, p. 93). 
Os seres humanos todos, em suas sociedades singulares, tradicionais ou modernas, criam categorias para os objetos, animais, plantas etc., mas fazem isso de maneiras diferentes. Isso não significa que um sistema de categorias seja melhor ou pior que o outro, que um tenha lógica e o outro esteja em um estágio anterior pré-lógico, como há muito se pensou dentro da antropologia $^{11}$, mas que os esquemas lógicos se constituem de modos muito distintos nas mais diversas sociedades. $\mathrm{O}$ olhar do pesquisador precisa estar atento aos seus próprios esquemas mentais, pelos quais opera sua cultura, para que isso não prejudique sua observação e busca por conhecer uma realidade cultural distinta da sua.

Ao mesmo tempo em que uma pessoa vivencia aspectos de uma determinada cultura, ela também a modifica com suas ações. As configurações culturais de uma determinada comunidade/sociedade não se mantêm inalterada com o tempo: as modificações sociais que estão pautadas na transformação humana da realidade material resultam em mudanças culturais (essa recíproca é também verdadeira). A cultura é, então, dinâmica. Compreender esse aspecto pode favorecer um entendimento de que a mudança nos hábitos, nas tradições, enfim, em tudo que está envolvido no termo cultura, não precisa ser considerado como algo bom ou ruim, mas como uma condição natural à existência humana - a transformação constante.

É importante destacar esse fator de mutabilidade da cultura no estudo aqui desenvolvido, pois, uma vez que foi proposto ouvir o que os jovens têm a dizer sobre o que se espera deles dentro de um ambiente de manifestação cultural, bem como sobre o modo como eles se veem dentro desse contexto, é natural que apareçam relações entre a sua condição juvenil e a transformação social (na perda/modificação das características culturais de sua comunidade), ou sobre sua importância na manutenção das características culturais vigentes. É a existência ou não desse conflito, sua repercussão na vida desses jovens e na vida da comunidade de modo geral, que configura o cerne da investigação proposta por este trabalho - acredita-se aqui que esse conjunto de fatores configura um rico processo educativo que merece ser conhecido e compreendido.

As mudanças dentro do universo da cultura ocorrem, citando propositalmente uma afirmação de Laraia (2009, p. 95), "porque os homens, ao contrário das formigas, têm a capacidade de questionar os seus próprios hábitos e modificá-los”. Com o passar do tempo, as

\footnotetext{
${ }^{11}$ Para saber mais sobre a questão da classificação em sociedades lógicas e pré-lógicas, consultar o capítulo 4 do livro de Roque de Barros Laraia, "A cultura tem uma lógica própria", presente no livro Cultura, um conceito antropológico, publicado pela Zahar em 2009.
} 
posturas, hábitos, crenças etc. de diferentes grupos sociais vão se modificando em ritmos bastante diversos. Os seres humanos pensam em suas práticas e julgam-nas mais adequadas ou menos adequadas à sua realidade vigente, daí a mudança (lenta ou rápida).

Ao se pensar nos jovens que vivem em uma comunidade considerada um remanescente de quilombo, que existe há cerca de duzentos anos, como é o caso da comunidade de Pinhões, onde se realiza o trabalho de campo aqui proposto, fica fácil imaginar o choque entre os costumes e as práticas que vêm sendo mantidos (com alterações, é claro) ao longo do tempo e os novos hábitos que são introduzidos, sobretudo por causa da proximidade dessa comunidade com uma grande metrópole. É fácil também imaginar a possibilidade de um choque entre as gerações sobre as questões relativas à manutenção de sua configuração cultural ou de sua modificação.

Sobre os dilemas que se relacionam aos processos transformadores na cultura, pode-se dizer que

Cada sistema cultural está sempre em mudança. Entender esta dinâmica é importante para atenuar o choque entre as gerações e evitar comportamentos preconceituosos. Da mesma forma que é fundamental para a humanidade a compreensão das diferenças entre povos de culturas diferentes, é necessário saber entender as diferenças que ocorrem dentro do mesmo sistema. Este é o único procedimento que prepara o homem para enfrentar serenamente este constante e admirável mundo novo do porvir (LARAIA, 2009, p. 101).

As sucessivas gerações dão nova configuração ao universo cultural no qual estão imersas. Muitas vezes o novo, nesse contexto, é visto com algo ruim, não desejado, como a morte do passado, a perda das raízes ou da identidade. A mudança, porém, é algo inevitável. A cultura se renova como o ser humano se renova com o passar do tempo. Também a congada, como manifestação cultural, passou por mudanças desde a época em que foi criada até os dias atuais. Tal constatação não significa que ela deixou de ser o que era, tornando-se melhor ou pior, apenas transformou-se em algo diferente.

Resta-nos então compreender de que modo o jovem relaciona-se com a cultura, com as mudanças e com a manutenção das tradições. O que os estudiosos nos informam sobre a relação dos jovens com a cultura? O que a sociedade espera/pode esperar do jovem? O que o jovem espera de si mesmo nesse contexto? 


\subsection{O jovem em sua relação com a cultura}

Por meio da educação, o conhecimento construído pelas sociedades em diferentes contextos históricos não se perde, mas é conservada. Eis um dos mais importantes papéis atribuídos à educação: preservar o legado cultural da humanidade. Essas ideias já percebidas de maneira dispersa em diferentes trabalhos tornaram-se mais intrigantes a partir da leitura do texto de Karl Mannheim (1968) sobre o assunto, uma vez que o autor mostrou uma interessante associação entre diferentes tipos de sociedades e a função que é atribuída à educação em cada uma delas.

Ao falar da juventude, Mannheim coloca-se na tarefa de escrever sobre o que a juventude pode oferecer à sociedade. Ele acredita que, para cumprir esse intuito ao qual se propôs, precisa partir do modo com se educa a juventude, uma vez que para ele os jovens retribuem à sociedade com suas ações na medida em que recebem um determinado tipo de educação com uma finalidade específica. Em outras palavras, a educação servirá ao propósito que se espera daqueles que estão sendo educados. Essa ideia se mostra bastante verdadeira na medida em que se constata que a educação não é algo neutro, que ela sempre tem uma intencionalidade.

Em quaisquer sociedades, há sempre algum objetivo em pauta quando se trata de educação. Nesse sentido,

Os processos ensino/aprendizagem são produtos altamente dependentes da estrutura organizacional do poder numa dada sociedade e da consequente reprodução ideológica que fazem os aparelhos e as instituições da sociedade civil. Deste modo, a educação não é jamais uma ação neutra, ela está sobre determinadas intencionalidades socioculturais e políticas que possuem os atores sociais que organizam, dominantemente, o poder econômico e político da sociedade (CONTRERAS, 1983, p. 27).

Nas observações de Mannheim (1968), uma vez que a juventude não tem o mesmo status ou significado em sociedades diferentes, distintas, também serão os objetivos relacionados à educação. Para ele "a mocidade pertence aos recursos latentes de que toda sociedade dispõe e de cuja mobilização depende sua vitalidade" (p. 71). Os jovens, nesse sentido, podem ser vistos como portadores de uma missão social que pode estar relacionada com a transformação ou com a manutenção das características vigentes. 
O autor faz, de modo esquemático, a diferenciação entre dois modelos básicos de sociedade nas quais os jovens poderiam ser arregimentados de diferentes maneiras. Primeiramente ele menciona sociedades cujas mudanças ocorrem de maneira bastante lenta, nas quais as pessoas mais velhas têm um maior prestígio. Os jovens, por sua vez, formarão uma "reserva latente", e "a educação destes será concentrada na transferência da tradição" (p. 72). Com relação às sociedades em que a transformação ocorre de modo rápido, nas quais se espera que haja mudanças na "fisionomia social ou política" (idem), os jovens farão o papel de agentes transformadores.

Essa ideia de que o jovem é um "agente revitalizador" (p. 73), nas palavras de Mannheim, ainda hoje se encontra presente em muitas obras sociológicas que tratam da juventude. Não são utilizados esses mesmos termos para tratar do assunto, mas o sentido se mantém: muitos estudos sobre os jovens estão pautados na ideia de transformação social. Colocar a juventude nesse contexto pode significar, muitas vezes, atribuir a ela a tarefa de renovação da sociedade e, segundo o autor, essa crença nas possibilidades de ação para a mudança estão relacionadas ao fato de que, pelo menos no campo sociológico, credita-se ao jovem uma entrada apenas parcial no "status quo da ordem social" (idem). A falta da imersão total dos jovens nas regras sociais possibilitaria a eles maior facilidade de ação no sentido de contestar a ordem vigente.

Ao continuar seu pensamento, Mannheim afirma que "a juventude não é progressista nem conservadora por índole, mas é uma potencialidade” (p. 74). Essas pessoas jovens agirão de uma ou de outra maneira de acordo com o modo com que forem envolvidas no processo de manutenção do status quo ou em sua modificação. Tal linha de pensamento pode conduzir o leitor a imaginar que os jovens agem somente por manipulação ou por influência de outrem, mas o objetivo do autor com esse raciocínio concentra-se em atribuir às condições sociais do convívio dos jovens primeiramente com sua família e posteriormente com as esferas da vida pública, cujos valores lhes são diferentes dos que conheceram durante sua infância - o fato de o jovem proceder de modo a corroborar com "ações revolucionárias" ou "reformadoras" (p. 75), por exemplo.

Numa crítica às ideias de Mannheim, Otávio Ianni (1968), em seu texto O jovem radical, contesta as ideias do autor ao enfatizar que, naquela perspectiva, "haveria como componente a-histórico do sistema social uma propriedade inovadora nas gerações, independentemente das condições reais, dadas por determinadas configurações estruturais" (p. 
232). Com isso, Ianni sugere que as afirmações de Mannheim sobre os jovens colocam-nos como seres sem interesses políticos e econômicos ainda definidos. Afirma ainda que tais afirmações são insuficientes para explicar as ações radicais ou não da juventude.

Para Ianni, ser ou não radical é uma condição que está posta pelas condições sociais em que as pessoas estão inseridas. Nesses termos, a conjuntura histórica de uma dada sociedade é essencial para compreender a postura da juventude. As discussões desses dois autores nesse aspecto giram em torno das explicações possíveis para a ação da juventude no contexto do fascismo na Alemanha ${ }^{12}$. É certo que não se podem desconsiderar as condições da sociedade da qual os jovens fazem parte se o objetivo for compreender seus modos de proceder. Tampouco é possível ignorar que a juventude, em contato com outros grupos sociais, toma consciência das contradições sociais e se posiciona quanto a elas.

Fato é que muito se espera da juventude e muito também se atribui a ela. Se for levado em consideração o papel do funcionalismo norte-americano, já mencionado anteriormente, na estruturação do pensamento sociológico sobre a juventude, notar-se-á que, ao encará-la como uma fase de "transição no ciclo da vida" e um "momento dramático de socialização" (PERALVA, 2007, p. 79), o teor das discussões que colocam o jovem no cerne de questões sobre a continuidade ou a ruptura das estruturas sociais poderá ser facilmente identificado.

Os diferentes olhares lançados sobre as características da condição juvenil em determinadas sociedades no que concerne ao seu papel social e à sua relação com a educação podem reconhecer diferentes modos de os jovens se relacionarem com outros grupos sociais e com o contexto sócio-histórico do ambiente onde vivem. Todos esses olhares são importantes no sentido de compreender o fenômeno juvenil no mundo. Certamente esse interesse pelos jovens tem uma explicação no modo como se enxerga suas contribuições para tecer a trama social.

Se um ou outro desses vieses faz recortes que permitem conhecer apenas parte da realidade juvenil, isso não deve ser visto como algo negativo, mas como possibilidades de análises que, mesmo sendo antagônicas, enriquecem as reflexões a respeito desse tema. A polêmica é sempre bem-vinda, desde que contribua para o desenvolvimento e a frutificação do pensamento.

\footnotetext{
${ }^{12}$ Nas décadas de 1930 e 1940, período de ascensão do regime fascista na Alemanha, a juventude de origem ariana (que excluía judeus e outras etnias) foi recrutada pelos ideais defendidos dentro dessa ideologia conservadora. 
Fato é que a sociedade espera algo das gerações mais jovens que são educadas no convívio social, em instituições de ensino etc. O controle social e a preservação cultural estão no cerne dos processos educativos. É preciso considerar nesse contexto que relação entre uma pessoa e o meio social onde ela nasce e se desenvolve tem um papel determinante em sua educação.

De acordo com Vigotski (2010), “o meio social é a verdadeira alavanca do processo educacional, e todo o papel do mestre consiste em direcionar essa alavanca” (p. 65). Da relação como o meio social, surgem as experiências que dão significado ao que deve ser aprendido.

Por mais que se queira ensinar algo aos jovens porque assim ficou determinado pelo sistema educacional, pelo estado ou por qualquer pessoa que se diga detentora de autoridade sobre as novas gerações, sem que se leve em consideração a experiência anterior adquirida no meio social, tal educação seria um arremedo do que ela realmente deveria ser. Tratar-se-ia apenas de um amontoado de conteúdos desconexos a serem assimilados pelas crianças e jovens.

É um equívoco considerar que a educação está nas mãos dos adultos, e estes decidem, ao seu sabor, o que os mais jovens precisam aprender. O mestre, aquele que ensina,

seria um louco se quisesse influenciar o crescimento das plantas, puxando-as diretamente do solo com as mãos, o pedagogo entraria em contradição com a natureza da educação se forçasse sua influência direta sobre a criança, mas o jardineiro influencia o crescimento da flor aumentando a temperatura, regulando a umidade, mudando a disposição das plantas vizinhas, selecionando e misturando terra e adubo, ou seja, mais uma vez agindo indiretamente, através das mudanças correspondentes ao meio (VIGOTSKI, 2010, p. 65-66).

Em se tratando de educação, deve-se levar em conta que o papel ativo daquele que aprende é essencial. Sua experiência, sua relação com o meio, são condições que influenciam diretamente sua formação. O mestre, nesse contexto, não apenas transmite um saber já pronto e desvinculado do meio social onde vive, porque "a educação se faz através da própria experiência do aluno, a qual é inteiramente determinada pelo meio, e nesse processo o papel do mestre consiste em organizar e regular o meio" (Ibidem, p. 67). O caminho da educação, nesse sentido, está assentado na ideia de que aqueles que ensinam não se colocam acima das 
crianças ou jovens impondo-se a eles e determinando o que devem aprender de modo arbitrário. Ao mestre, cabe abrir uma janela e apontar o horizonte.

As investigações sociais, nas últimas décadas, têm prezado pelo reconhecimento do jovem como ser ativo, dotado de uma opinião sobre si e sobre o mundo. Têm também reconhecido o papel das novas gerações na construção da sociedade. Juarez Dayrell, ao trabalhar com essa ideia de jovens como sujeitos sociais, menciona a definição de Charlot (2000, p. 33, 51), segundo a qual "sujeito é um ser humano aberto a um mundo que possui uma historicidade; é portador de desejos e é movido por eles, além de estar em relação com outros seres humanos, também sujeitos" (DAYRELL, 2007, p. 159).

O autor continua suas reflexões afirmando que "ao mesmo tempo, o sujeito é um ser social, com uma determinada origem familiar, que ocupa um determinado lugar social e se encontra inserido em relações sociais" (idem).

Levar em consideração o jovem como sujeito construtor de sua realidade é algo bastante significativo. Dayrell fala de sua experiência com jovens participantes de grupos de rap e funk e do modo com eles lhe pareceram construir singularmente a sua condição de sujeitos sociais. Na busca por compreender qual é o papel dos jovens no ambiente em que se inserem e como se veem nesse processo, é importante destacar que eles têm algo a dizer sobre si e seu modo de estar no mundo. O autor continua afirmando que "Tomar os jovens como sujeitos não se reduz a uma opção teórica. Diz respeito a uma postura metodológica e ética, não apenas durante o processo de pesquisa, mas também em meu cotidiano como educador" (ibidem, p. 161). Essa também é a postura que será adotada neste trabalho.

Os jovens, sujeitos de sua história, têm então um papel fundamental em se tratando da manutenção ou modificação da cultura. Que papel seria esse? Que tarefa de fato cabe aos jovens? É importante que procuremos compreender qual é a relação que os jovens estabelecem com o passado. Uma pista nesse sentido é compreender o papel da tradição na ligação entre o passado e o futuro.

\subsection{Juventude e tradição}

A palavra juventude traz consigo muitas vezes a imagem do novo, da renovação, da modificação daquilo que está posto. A ligação da figura do jovem com o passado é algo no 
mínimo estranho. Contudo, é justamente no jovem (e também na criança e no adolescente) que está imerso no processo educativo que se deposita a esperança de não deixar o legado do passado humano se perder. Essa relação entre o passado e o futuro é algo bastante complexo. Que nome dar a esse fenômeno? De que modo essa relação é estabelecida? Como o jovem se insere nesse contexto?

Em suas reflexões sobre o universo da política, Hanna Arendt (2013) trabalha com a ideia de um elo que liga o passado ao futuro. Em suas palavras,

\begin{abstract}
o homem na plena realidade de seu ser concreto vive nessa lacuna temporal entre o passado e o futuro. Suspeito que essa lacuna não seja um fenômeno moderno, e talvez nem mesmo um dado histórico, e sim coeva da existência do homem sobre a terra. Ela bem pode ser a região do espírito, ou antes, a trilha plainada pelo pensar, essa pequena picada do não-tempo aberta pela atividade do pensamento através do espaço-tempo de homens mortais e na qual o curso do pensamento, da recordação e da antecipação salvam quem quer que toquem da ruína do tempo histórico e biográfico (ARENDT, 2013, p. 39-40).
\end{abstract}

Não se vive no passado ou no futuro, mas no agora, no tempo presente. Contudo, existe uma trilha milenar já traçada pelo homem e também o devir, que aparecem juntos no pensar humano como uma linha reta. O que une todos esses tempos, segundo Arendt (2013), o que está entre o passado e o futuro formando um elo é a tradição.

A tradição pode ser compreendida como um caminho pelo qual as experiências do passado são apresentadas às novas gerações. Sem ela "parece não haver nenhuma continuidade no tempo e, portanto, humanamente falando, nem passado nem futuro, mas tãosomente a sempiterna mudança do mundo e o ciclo biológico das criaturas que nele vivem (ARENDT, 2013, p. 31)”. Esse importante papel da tradição dá a ela legitimidade e por isso não se faz necessário buscar comprovações sobre a importância ou sobre a veracidade de seu conteúdo. É a tradição que "seleciona", "transmite" e "preserva" os tesouros do passado humano (Ibidem, p. 31). E como o jovem pode se relacionar com a tradição?

Ao jovem, sujeito social, cabe, segundo as palavras de Tunes ${ }^{13}$, "Carregar o passado para o futuro". Essa ideia está contida tantos nos sistemas educacionais como na vida cotidiana, em que todo um conjunto de crenças e saberes são repassados de geração em

\footnotetext{
${ }^{13}$ Frase mencionada pela professora Elizabeth Tunes em considerações feitas na banca de qualificação do mestrado ocorrida no dia 26 de setembro de 2014 na Universidade de Brasília - UnB.
} 
geração, perpetuando-se no tempo - não sem alterações. Mas que nome dar a esse processo de transmissão daquilo que foi construído no passado e perpetuado por meio da sua transferência às sucessivas gerações? É importante então compreender de que maneira os jovens se relacionam com a tradição, tanto da perspectiva daqueles que os educam, quanto da sua própria perspectiva.

Ao jovem cabe a tarefa de receber um legado e de construí-lo novamente a seu modo, preservando, quando possível, aquilo que permaneceu coletivamente na memória. Nesse sentido,

este pequeno espaço intemporal no âmago do tempo, ao contrário do mundo e da cultura em que nascemos, não pode ser herdado e recebido do passado, mas apenas indicado; cada nova geração, e na verdade cada novo ser humano, inserindo-se entre um passado infinito e um futuro infinito, deve descobri-lo e, laboriosamente, pavimentá-lo de novo (ARENDT, 2013, p. 40).

As novas gerações constroem, com aquilo que recebem de seus antepassados, uma nova realidade. Transformam seu legado em algo novo, não por rebeldia, mas porque não é possível manter intacto aquilo que receberam. Nesse sentido, cada nova geração descobre seu "tesouro" (ibidem, p. 31) e transforma-o de acordo com sua experiência no mundo.

É possível observar, com base nas obras aqui trabalhadas, que o jovem, ou as novas gerações, tem um papel fundamental no que se refere às questões relacionadas à tradição. De forma esquemática, é possível enxergá-lo da seguinte maneira:

Tradição/cultura/educação

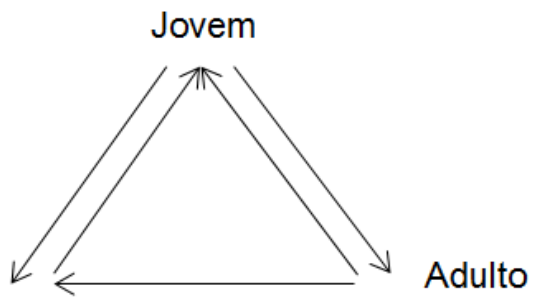

Figura 1 (representação da relação jovens, adultos e educação) 
Nesse sentido, o jovem recebe influência do adulto por meio da convivência com ele em diversas situações. Por meio da educação, por exemplo, o adulto procura controlar os processos de formação dos mais jovens a fim de direcionar suas escolhas. No âmbito da cultura e da tradição, a presença do adulto é de autoridade, daquele que detém o conhecimento sobre o passado e está disposto a transmiti-lo à sua maneira aos mais jovens. O jovem, por sua vez, pode transformar aquilo que recebe por influência do adulto em algo novo. Ou, nas palavras de Arendt (2013, p. 40), "pavimenta" a realidade a seu modo, deixando também seu legado.

No âmbito da cultura, na qual se localizam as manifestações culturais, tradicionais ou não, é possível perceber esse contexto. No caso da congada, que é o espaço da investigação aqui proposta, nota-se grande presença de crianças e jovens entre os adultos, colocando em prática passos de dança, rezas e músicas, acompanhando uma procissão que percorre o vilarejo e termina na capela de devoção a Nossa Senhora do Rosário, onde promessas são pagas e uma missa é celebrada em homenagem à padroeira. Eles poderiam estar em qualquer outro lugar, mas estão naquele momento desenvolvendo aquela atividade e não outra.

Se o jovem carrega o passado para o futuro, que passado é esse contido na congada que está sendo trazido para o presente e levado de herança para as gerações futuras? O que de fato é a congada? Que elementos a compõem? O que nela é considerado tradicional? Com que aspectos da congada os jovens de Pinhões se identificam para permanecerem participando dela? 


\section{CAPÍTULO III: ELEMENTOS TRADICIONAIS NA CONGADA}

A congada trata-se de uma festa religiosa que envolve elementos da cultura africana e do Cristianismo. Ela existe no Brasil desde o período colonial, em que se fazia necessário aos brancos garantir a ordem frente à grande população de escravos africanos e aos negros expressar sua cultura, mesmo que de modo incompleto e modificado. O que é tradicional na congada? A devoção e os traços africanos ainda estão presentes nessa manifestação cultural? Este capítulo traz informações acerca da congada e das tradições que se fazem presentes nela.

\subsection{O olhar dos folcloristas sobre a congada}

Muitos estudos feitos sobre a cultura brasileira partem da perspectiva de que é preciso conservar a memória, o passado. Os folcloristas, por exemplo, costumam pensar na preservação do folclore para as gerações futuras. Nessa perspectiva, a mudança é vista com 
desconfiança, como se fosse uma violação do passado ou a determinação de seu prazo de validade, sua morte. Insiste-se muito em registrar, catalogar, sistematizar as informações a fim de que elas não se percam no tempo. Mais raros, porém, são os estudos que se dedicam a observar a transformação e a mudança como algo intrínseco às manifestações culturais.

A tarefa de registrar e preservar o passado em si não é de forma alguma negativa. Contudo, o preconceito com relação à mudança é capaz de gerar equívocos interpretativos que colaboram para a compreensão de questões ligadas à cultura. Um texto que trata da congada traduz bem como as transformações trazidas pelo tempo podem ser vistas de modo bastante negativo.

A coreografia conseguia mesmo ser miserável, consistindo exclusivamente num levar (cada pé por sua vez) o pé pra frente, à distância de meio passo, aí apoiá-lo no chão, erguê-lo nesse lugar, batê-lo de leve nesse mesmo lugar e trazê-lo de novo pro ponto primeiro, ficando, pois, os pés novamente juntos (ANDRADE, 2002, p. 719).

O trecho acima foi retirado do texto de Mário de Andrade produzido durante a realização da Missão de Pesquisa Folclórica, ainda na década de 1930. Neles o autor descreve a Congada Vila de Lindóia do Estado de São Paulo e insiste na pobreza dos movimentos, da música e das vestes. Mais adiante o autor continua:

Sabia todos os textos e canções de cor, e os deu tais e quais vão adiante, terrivelmente deformados, como se verá. Isto caracteriza mais uma vez a passividade extrema com que também aqui no Brasil central, como no Nordeste, os indivíduos decoram os textos sem quase nenhuma reação intelectual, sem mesmo, por assim dizer, quase sem nenhum esforço, nenhum desejo de compreender (Ibidem, p. 723).

A participação das pessoas é vista por Mário de Andrade como algo bastante pobre, sem reflexão. Elas estariam, segundo seu olhar, apenas repetindo aquilo que ouviram de outros sem pensar ou se expressar a respeito do que acontecia. Do ponto de vista estético (da dança, do movimento do corpo, do figurino, da entonação das canções), o olhar do autor estava voltado para uma pretensa época de ouro do folclore brasileiro situado em um passado já perdido no qual o folclore, em suas diversas manifestações, era considerado bem mais rico. Outro fator que contribuía para uma visão que descrevia as manifestações culturais chamadas folclóricas como pobres e carentes de "reação intelectual", como afirma Mário de Andrade (2002, p. 723), é que muitos pesquisadores partiam de esquema mental centrado na cultura 
erudita, que acabava se tornando um modelo da observação e descrição das atividades culturais folclóricas.

Os dois trechos acima foram escolhidos com o intuito de situar o contexto em que foi produzida boa parte dos textos que tratam das manifestações culturais populares brasileiras. As ideias sobre folclore que pautavam esse tipo de produção pareciam estar assentadas naquelas defendidas por folcloristas internacionais, como o purismo, a originalidade e a conservação do passado. Além disso, é preciso mencionar que boa parte dos estudos folclóricos, como os de Mário de Andrade, foi feita dentro do contexto de construção de uma identidade nacional para os brasileiros, bem como da modernização do país, na qual "o elemento folclórico é percebido neste momento como vestígio do passado, como sobrevivência e etapas menos evoluídas da experiência social para o atingimento de um modo de ser moderno" (MORAES, 2000, p. 75).

Ao mesmo tempo em que se queria preservar o folclore como legítimo representante da identidade nacional, no contexto em que o cenário político favorecia até mesmo a introdução dessas manifestações culturais nas escolas como meio de mantê-las vivas, ele era visto como atraso dentro de um contexto de modernização. Esse é também um motivo provável para sua depreciação.

Os trabalhos que se dedicam ao folclore ou às manifestações culturais populares têm adotado recentemente um caminho distinto daquele traçado entre as décadas de 1920 e 1960, período no qual prevaleciam estudos do tipo mencionado acima. Atualmente a tendência tem sido partir da cultura para investigar diversas questões ligadas à experiência humana no cotidiano. A congada, como tantas outras manifestações culturais, pode ser a base para a investigação de diversas questões sociais, a exemplo das relações educativas.

Nas últimas décadas, houve um aprimoramento da legislação que define e protege elementos materiais e imateriais da cultura. Nesse sentido, até mesmo as crenças, os modos de proceder, de se vestir, de falar, sejam eles considerados tradicionais ou representativos da cultura de determinada sociedade, são passíveis de proteção e preservação para as gerações futuras. Essas mudanças fazem parte de um movimento internacional relacionado à preservação cultural que ressoou aqui no Brasil. 
De qualquer modo, com ou sem catalogação, com ou sem legislação as manifestações culturais estão aí postas para lembrar-nos de que existe um passado para ser lembrado, elaborado de novo, transformado em algo novo.

A congada é uma dessas festas que reúne elementos do passado escravista e cristão brasileiro. Ela remete ao fato de que uma imensa população negra africana foi arrancada de sua terra e trazida para cá à força. Lembra-nos de que a cultura trazida com os escravos foi misturada àquela construída aqui pelos portugueses, gerando uma nova. Há, nesse sentido, cerca de quinhentos anos de memórias transmitidas, assimiladas e modificadas diversas vezes. A congada carrega toda essa simbologia atrelada à condição do escravo negro que precisou modificar seu modo de estar no mundo, criando outro. Que elementos são esses que configuram a simbologia presente na congada?

\subsection{O aspecto religioso na congada}

Congados, congo ou congada são palavras utilizadas nos escritos de folcloristas e autores brasileiros para designar um fenômeno cultural que é descrito de diversas maneiras: Câmara Cascudo chamou-a de auto; Mário de Andrade, de dança dramática; Edison Carneiro preferiu debater com Mário de Andrade negando a pertinência do termo por ele utilizado e voltar aos termos danças, cortejos, desfiles, autos ou jogos, que considerava mais apropriados.

Certamente, pelo exposto, é possível concluir que não há um consenso sobre que tipo de manifestação cultural se está falando ao se tratar da congada (nem mesmo há uma única denominação para ela). Contudo, nas descrições que são feitas, há unanimidade quanto ao fator religioso que deu origem a ela.

Não apenas a congada, mas muitas manifestações que fazem parte do universo cultural brasileiro, estão alicerçadas sobre o ritual católico, com seu calendário litúrgico e seus santos. Os colonos portugueses professavam a fé cristã católica que trouxeram consigo da Europa e aclimataram em seu novo lar.

Segundo Roger Bastide (1959, p. 16), "eis que se abria ao catolicismo um mundo novo que ele podia moldar à sua feição: um continente virgem, a que podia impor o ritmo único das comemorações dos eventos da vida de Cristo". Segundo o autor, o colono português, mais especificamente o clero católico aqui instalado, acabava utilizando-se de elementos do 
cotidiano de escravos e índios para introduzir a evangelização, colocando essa tarefa como missão. Aliás, era obrigação dos colonos batizar os cativos ainda em território africano ou assim que desembarcavam na Colônia. A eles eram dados nomes cristãos e logo eram introduzidos nos hábitos referentes ao culto católico.

É importante compreender que as tradições de execução de autos e outras festas com temas cristãos já faziam parte do repertório cultural tanto em Portugal quanto no restante da Europa. Os padres que vieram para o Brasil com o intuito de contribuir para a colonização com sua missão evangelizadora, muitas vezes utilizaram esses recursos para se aproximar de indígenas e africanos. Sobre a presença dessas festividades de origem europeia no contexto colonial, sabe-se que os autos de Natal e outras dramatizações trazidas pelos padres jesuítas

\begin{abstract}
incorporaram às partes litúrgicas pequenos e inocentes dramas que simulam, inclusive, cenas de visitações com cortejos processionais. Cortejos com cantos e danças estenderam-se dos primeiros rituais jesuíticos de catequese para os solenes festejos aos santos padroeiros ou santos de preceito católico mais amplo. Alegres danças, de que as folias portuguesas seriam um exemplo, faziam parte de dramatizações devocionais realizadas tanto no interior das igrejas quanto nas procissões que percorrem ruas de cidades e povoados. Elas aparecem em cerimônias litúrgicas dos seguintes ciclos e festas: Natal (até a Epifania), Páscoa, Pentecostes, Corpo de Deus (BRANDÃO, 1984, p. 61-62).
\end{abstract}

Um conjunto de costumes e ações festivas ligadas ao culto católico espalhou--se pelo território do Brasil e foi com o tempo sendo modificado e transformado em uma estrutura cultural própria da Colônia. Elementos indígenas e africanos foram aos poucos sendo incorporados, com ou sem a permissão dos colonos ou clérigos, dando ao universo cultural brasileiro características bastante peculiares.

Quer seja para manter os escravos passivos, aculturando-os e dando a ideia de que podiam também ter seus momentos de lazer e festas religiosas ou não, quer seja algo bastante diferente disso: a entrada da população negra nos esquemas culturais da Colônia incorporando alguns valores e mantendo outros que eram seus como forma de defesa. A realidade àquela época era a existência de ricas festividades ligadas à Igreja que foram se modificando ao longo do tempo, dando origem a tantas outras que hoje compõem o universo cultural brasileiro. 
Ao descrever o ritual da congada, geralmente são mencionados os elementos que compõem essa manifestação cultural: a presença da devoção a um santo (Nossa Senhora do Rosário, São Benedito e Santa Efigênia), a dramatização de uma luta (que podia ser travada entre mouros e cristãos, entre tribos africanas), a coroação dos reis congos, tudo isso regado a música, passos de dança e representações teatrais. Os congados percorrem as ruas vizinhas, visitam as casas, encenam suas lutas, cantam, dançam, coroam seus reis, participam de uma missa para o santo de devoção e terminam sua festa com um banquete, do qual todas as pessoas que participam do ritual ou estão presentes podem participar. Com algumas variações, esse é o ritual da congada que está presente em diferentes regiões do país.

Para alguns autores que elegem a escravidão como tema de estudo, a relação entre o catolicismo e a população negra deu-se em termos de sua utilização para a dominação dos escravos. Nesse sentido,

Trata-se de emprestar das civilizações africanas elementos utilizáveis, mas, trocando-lhes a função: por exemplo, a existência dos reinos africanos para sagrar os reis do Congo, mas no interior da igreja a fim de que os reis sirvam de intermediários entre o branco e a massa dos homens de cor na fiscalização dos costumes africanos [...] (BASTIDE, 1959, p. 19).

De fato, a religião cristã serviu de instrumento para certo controle dos colonos portugueses sobre a população africana que foi introduzida no ambiente da Colônia, como propõe Roger Bastide. Certamente não devem ser ignoradas as questões políticas, étnicas etc. na relação entre africanos e portugueses no contexto colonial, bem como as consequências dessa relação, sobretudo para os escravos. Acredita- se aqui, no entanto, que essa realidade era bem mais complexa e não se resumia apenas à dominação por parte dos colonos ou da aculturação por parte dos africanos. O que se quer destacar aqui, por hora, é que a presença dessa religiosidade nas relações colonos-escravos e a união entre elementos da cultura cristã e africana acabaram resultando em ricas manifestações culturais.

Contemporaneamente, a religiosidade ainda é o subsídio central da congada. E esse é um dos fatores que estão no âmago daquilo que é transmitido em termos de saberes nesse contexto cultural. As rezas, canções, memórias sobre um passado religioso estão presentes em todos os momentos de ensaios e da realização da congada em si. As pessoas que já conhecem os rituais, os passos, as melodias, acabam por se tornarem transmissoras desses saberes àqueles que se interessam por aprender. Aliados ao saber que está propriamente vinculado à 
congada estão tantos outros que, intencionalmente ou não, são repassados de geração em geração.

\title{
3.3 A congada como festa de devoção dos negros
}

Os relatos de historiadores, folcloristas e tantos outros pesquisadores das manifestações culturais brasileiras dão a entender que a congada faz parte do universo devocional da população negra no Brasil desde o período colonial em que surgiu. Já nos primeiros textos que são produzidos no Brasil descrevendo os fazeres dos congados, há menção sobre presença de elementos da cultura africana nessas festividades. Desse modo, a congada pode ser definida como

\begin{abstract}
Autos brasileiros de assuntos africanos, especialmente reminiscências da rainha Njinga de Angola, falecida a 17 de dezembro de 1663. O tema essencial é a embaixada da rainha Ginga a um potentado negro, às vezes, Henrique rei Cariongo, nome que recorda uma das circunscrições de Luanda, e que outrora foi sobado independente. O enredo referir-se-ia a uma luta entre a guerreira Ginga e um soba de Cariongo, transformado em rei, e não um rei do Congo. É auto popular em todo o Brasil, tendo variantes onde desaparece a rainha e figura sempre um embaixador, que luta e vence o rei local. Noutras regiões, o príncipe vencido e morto é ressuscitado pelo feiticeiro, e tudo acaba em dança e canto (CÂMARA CASCUDO, 2000, p. 138).
\end{abstract}

A maior parte dos folcloristas faziam descrições semelhantes à de Câmara Cascudo, limitando-se a retratar as vestes, transcrever as canções, anotar tudo o que fosse possível com o intuito principal de catalogar as informações sobre as manifestações culturais para que não desaparecesse sem deixar registro. Tais registros não deixam transparecer a intenção de compreender o sentido do que estava em andamento para a comunidade em que as festividades ocorriam, mas sim catalogar para preservar.

Alguns estudiosos da escravidão no Brasil lançaram seu olhar sobre essas questões e passaram a escrever a respeito da dominação imposta à população negra por diversos meios, inclusive pela religião. Tais autores chamam a atenção para a imposição do catolicismo pela introdução de elementos identificáveis pelos africanos em seu meio, a fim de conseguir substituir suas crenças pela aproximação entre esses elementos familiares e os que precisavam ser ainda compreendidos e incorporados. 
Nesse sentido, autores que escreveram décadas atrás, como Roger Bastide, que mostra como a junção de elementos católicos e da cultura africana em festas e rituais, formando o que ele chama de "folclore artificial" (1959, p. 22), facilitou a prevalência do colono sobre os escravos. Outros autores que são bem mais recentes partilham de uma mesma opinião: a dominação dos colonos se fez também por meio da disseminação do ritual e dos valores católicos. Toda uma situação é geralmente descrita ao se tratar desse tema, a saber, a necessidade de controle da população escrava, a tentativa de introduzi-los na fé cristã, a necessidade dos próprios africanos de expressar de algum modo a sua fé.

No que se refere especificamente à congada como manifestação que engloba a questão religiosa cristã e os elementos da cultura africana, é possível dizer que

\begin{abstract}
A classe dominante, percebendo que as coroações caíam bem no gosto dos povos negros, utilizava desse recurso para controlar suas manifestações e colaborava emprestando suas joias. As autoridades prestigiavam a solenidade para se assegurar da quietação e disciplina dos escravos que se rejubilavam vendo o seu rei coroado. $\mathrm{O}$ esplendor da festa se dava pelos empréstimos de joias, adereços e trajes riquíssimos, cedidos pelos amos. A festa reunia os escravos, mestiços e forros que em procissão buscavam o régio casal, que eram levados à Igreja, onde era coroado pelo vigário (CÂMARA CASCUDO, 2000, P. 150).
\end{abstract}

No trecho acima, escrito ainda dentro do contexto em que se davam as produções dos folcloristas brasileiros, dos quais Câmara Cascudo é um ilustre representante, aparece além da descrição do acontecimento em si, a ideia de que por meio de algumas concessões e agrados os colonos mantinham os cativos sob seu controle.

Mais recentemente outros autores têm buscado compreender o contexto em que estavam inseridos colonos e escravos, que resultaram no aparecimento de manifestações como a Congada, no sentido de lançar luz sobre as intenções com as quais se permitia ou se incentivava a introdução de elementos da cultura africana em rituais ou festas herdadas da cristandade europeia. As informações que podem ser extraídas de tal realidade muitas vezes levam a entender que

Esse evento permitindo simbolicamente que os negros tivessem seus reis foi um recurso utilizado pelo poder do Estado e da Igreja para controle dos escravos. Era uma forma de manutenção aparente de uma organização social dos negros, uma sobrevivência que se transformou em fundamentação mítica. Na ausência de sua sociedade original, onde os reis tinham a função real de liderança, os negros passaram a ver nos reis do Congo os 
elementos intermediários para o trato com o sagrado (GOMES; PEREIRA, 2000, p.244, apud DOS SANTOS, 2011, p. 24).

É provável que houvesse entre os colonos brancos o medo de revoltas de escravos que colocassem em ameaça sua vida. A população escrava de fato chegava a ser bem maior que a de brancos em muitos lugares da Colônia. Contudo, nos trechos acima, transparece uma visão muito passiva da população negra. Conforme já foi mencionado, acredita-se aqui que as relações entre negros e brancos no Brasil colonial eram bem mais complexas do que muitos estudos deixam transparecer. Há todo um movimento dentro de diferentes campos do saber, sobretudo na História (mais especificamente na escola histórica conhecida como história cultural), em que tais relações têm sido colocadas à prova.

Para compreender tal complexidade, basta imaginar que as pessoas arrancadas de sua terra natal e trazidas para um ambiente hostil e desconhecido não deixavam lá toda a bagagem cultural de que dispunham. Uma vez no território da Colônia, suas crenças, seu modo de estar no mundo, apesar de submetidos ao cativeiro, não deixavam de existir; ao contrário, passavam a misturar-se com a nova realidade à qual estavam submetidas. Do mesmo modo, a convivência dos africanos com a população branca que o escravizava não se girava em torno da passividade, mas dos acordos e conflitos ${ }^{14}$.

Não há como se negar a importância dos elementos da cultura africana nos rituais e festas que formam o universo cultural brasileiro. Tampouco fiar-se na crença de que tais elementos não sofreram alterações com a chegada à Colônia, pois

essa rica experiência rítmica e dramático-coreográfica que, a partir do século XVI, passou às Américas com os negros africanos transformados em escravos pelos interesses do capitalismo comercial europeu, mas para sofrer desde logo um progressivo processo de desintegração (TINHORÃO, 2001, p. 162).

Em vista da rica discussão que se trava em torno das questões referentes às relações estabelecidas entre brancos e negros no ambiente colonial e ao longo da história brasileira, importantes informações devem ser ressaltadas a fim de que o trabalho aqui proposto não se mantenha alheio ou assuma uma postura ingênua e apolítica. $\mathrm{O}$ fato de existirem ainda hoje

\footnotetext{
${ }^{14}$ Para saber mais sobre a questão das relações sociais entre negros e brancos no Brasil colonial dentro dessa perspectiva revisionista que propõe enxergar acordos e conflitos nas relações sociais e reconhecer a ação de cada um dos grupos sociais, dando a elas sua devida importância, consultar a obra de Douglas Cole Libby e Eduardo França Paiva, A escravidão no Brasil: relações sociais, acordos e conflitos. São Paulo: Moderna, 2000.
} 
manifestações culturais como a congada, cujas origens remontam ao século XVII, deve ser um indicador de que algo importante ocorreu no passado em termos de configuração de uma nova cultura, carregada de características herdadas de culturas muito distintas (africana e europeia, no caso) e que se perpetuou no tempo apesar das mudanças que certamente sofreu e esta é uma característica primordial da cultura conforme já mencionado: sua dinamicidade.

Então, levando-se em consideração o modo como se formou a congada, com todas as intenções, explícitas ou não, dos grupos sociais envolvidos nessa empreitada, este trabalho caminha agora para a investigação de campo. Os textos que se desenvolvem a seguir têm por objetivo: estabelecer os parâmetros metodológicos a serem utilizados para o trabalho de campo; descrever os grupos e o local da pesquisa; analisar os dados referentes à coleta feita em campo com base nos conceitos estabelecidos anteriormente.

\section{CAPÍTULO IV: A COMUNIDADE DE PINHÕES, UM LUGAR, UM CAMINHO}

A primeira parte deste trabalho foi dedicada a apresentar as discussões em torno do que é ser jovem e de como os autores que escrevem sobre juventude têm abordado esse tema dentro e fora do Brasil. Vimos que diversas questões estão envolvidas na delimitação do que seja essa fase da vida e que uma diferenciação entre criança, adolescente e jovem tem sido feita principalmente no sentido de estabelecer políticas públicas que atendam de modo específico a cada faixa etária. 
O interesse pela definição de juventude está ligado principalmente ao papel que o jovem tem dentro de uma comunidade, uma sociedade, um país, um povo. Os adultos estabelecem de forma consciente ou não o que fará parte da educação dos jovens de acordo com o que esperam deles: que sejam agentes de mudança ou de manutenção da cultura.

Os autores trabalhados deixam entrever que o jovem não nasce para esse ou aquele papel que lhe é atribuído, mas pode desempenhá-lo conforme o ambiente onde vive e se assim o decidir. Ressaltam também que o jovem é um ser único e dotado de vontade, que estabelece sua trajetória e constrói sua própria história, encontrando seu próprio caminho dentro do que foi traçado para ele pelos adultos. Esse jovem, ser singular, passa por um processo educativo, que ocorre em diferentes espaços ao mesmo tempo, mas o foco dos estudiosos costuma se concentrar na educação escolarizada ao falar do jovem.

Os estudos que tratam da educação da juventude no Brasil também têm como tema central a escola e os problemas associados a ela e procuram dentro e fora dela explicações para o fracasso de boa parte dos estudantes. Nas últimas cinco décadas, foram levantadas questões sobre a inserção de elementos não formais (do cotidiano) na educação escolarizada como um modo de aproximar o conteúdo ali administrado e a realidade dos estudantes. Contudo, essa aproximação não foi capaz de solucionar os problemas relacionados à compartimentação e à falta de sentido do currículo escolar.

Em vista dessa realidade, foi sinalizado que há um problema central na educação escolarizada, que passa pela ausência da liberdade e da vontade daquele que deve aprender, com relação aos processos que ocorrem dentro dessa instituição. E que a figura do mestre precisa ser a daquele que aponta um caminho, mas não obriga seu pupilo a segui-lo por considerar tal caminho melhor que outros.

Ainda nessa primeira parte, foi indicada a investigação dos processos educativos que ocorrem no seio da cultura como uma pista para se desvendar o interesse humano em educar as novas gerações e como elas encontram seu próprio caminho nesse contexto. Destacou-se que é necessário ter ferramentas teóricas para identificar o modo como a cultura opera para conseguir observar nela o que se procura como resposta. Desse modo, identificou-se que a cultura é formada por padrões e regras que moldam o comportamento humano e que isso não está explícito nem para os que estão imersos nos fenômenos culturais nem para quem apenas os observa, sendo necessário, portanto, ver e interpretar. 
Dentro das possibilidades investigativas no âmbito da cultura, ressaltamos ainda que cada ser humano participa dos fenômenos à sua maneira e que diferentes gerações transformam o que está posto em algo novo (fator de mutabilidade). Isso dá aos fenômenos culturais sua característica dinâmica. A relação do jovem com a cultura, nesse sentido, pode ser ao mesmo tempo de preservação e transformação.

Para compreender essa relação complexa entre a juventude e a cultura, lança-se mão do conceito de tradição trabalhado por Hanna Arendt em seus escritos sobre política. A autora coloca a tradição como aquela que liga o passado ao futuro. Utilizando então uma analogia, defende-se aqui que o jovem é o agente que faz esse papel de "carregar o passado para o futuro" (o jovem leva a tradição adiante), conforme destacou Elizabeth Tunes na primeira avaliação deste trabalho.

Uma vez estabelecidas essas ideias, passa-se a tratar dos elementos que configuram a tradição dentro da congada, fenômeno cultural que serve de base para a esta investigação. Observa-se que a religião cristã e elementos da cultura africana, que se misturaram configurando uma nova realidade cultural no Brasil colonial, fazem parte desse legado que foi deixado aos jovens brasileiros que participam desse tipo de festividade.

Desse modo, parte-se então para a segunda parte deste trabalho, que traz algumas informações sobre a comunidade de Pinhões, o grupo de congada em questão e o grupo de jovens entrevistados. Em seguida, é feita a análise das falas desses jovens, à luz do caminho construído na parte anterior deste trabalho. Além das falas dos jovens, são levadas em consideração as falas de dois mestres e de uma moradora da comunidade, que abriu as portas de sua casa, recebeu-nos nos dias da festa de Nossa Senhora do Rosário e contribuiu imensamente para a compreensão dos objetivos delimitados aqui.

\subsection{A comunidade de Pinhões}

Pinhões é um vilarejo que abriga cerca de trezentas e oitenta famílias, que garantem seu sustento por meio de atividades diversas, sobretudo da agricultura. Fica há cerca de quinze quilômetros de Santa Luzia, cidade que faz parte da região metropolitana de Belo Horizonte, em Minas Gerais. 
A própria população refere-se a Pinhões como um remanescente de quilombo, que teria sido construído no contexto da escravidão em Minas Gerais. Sua história se liga à de Santa Luzia, que surgiu como vila ainda no século XVIII por causa da atividade mineradora no interior da capitania mineira. O vilarejo ganhou esse nome por conta da grande quantidade de árvores que produzem um fruto chamado pinhão nesse local.

A comunidade costuma repetir que os escravos que construíram o quilombo haviam fugido das fazendas de Santa Luzia e também do Convento de Macaúbas (que funciona até hoje e abriga freiras enclausuradas). Essas pessoas então passaram a viver em Pinhões e a fazer do vilarejo sua casa. Entre os moradores, há uma grande quantidade de pessoas que possui laços de parentesco umas com as outras.

Ao entrar em Pinhões, podem ser avistadas muitas casas de aspecto simples ao longo de uma rua principal que atravessa o vilarejo. Há um pequeno comércio nessa rua principal e uma escola que atende à população do lugar com turmas de Ensino Fundamental e Médio.

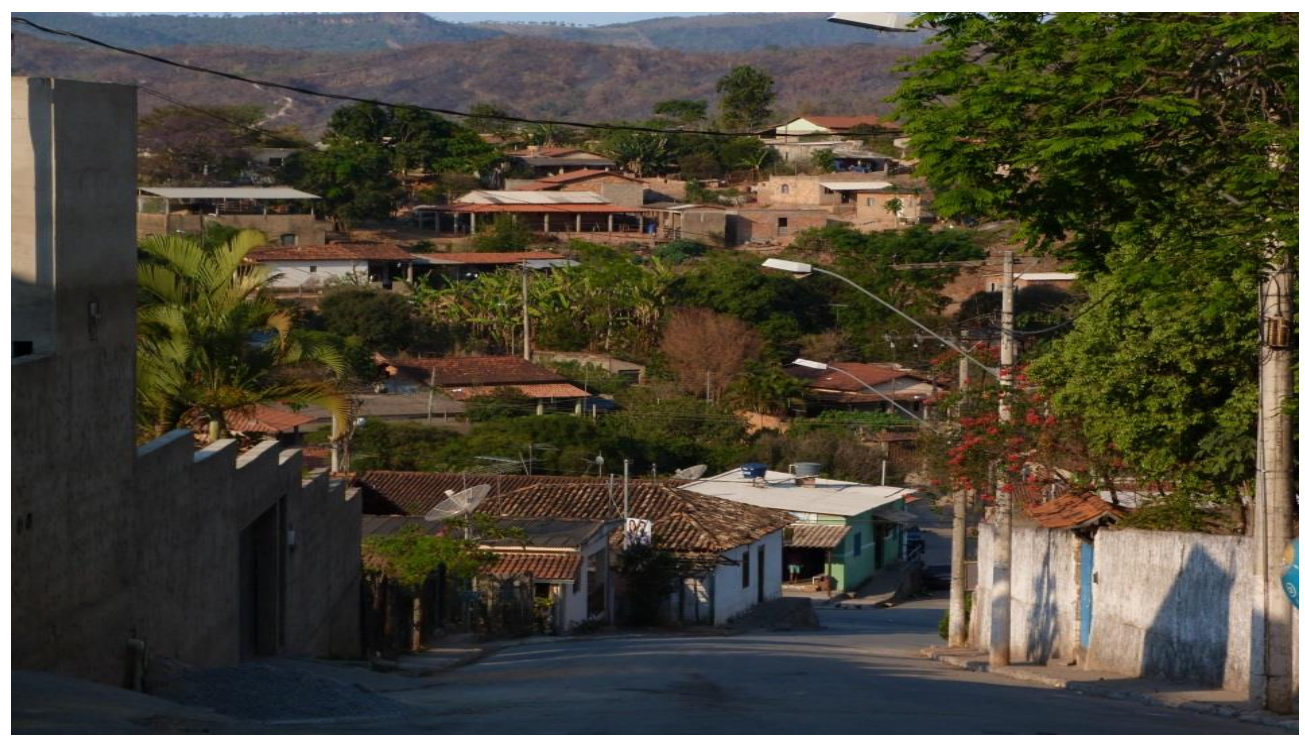

Figura 2 - Vista do vilarejo de Pinhões

No alto da ladeira, abraçando a comunidade, está a capela de Nossa Senhora do Rosário. Conta-se que foi erguida uma ermida ainda no final do século XIX, e as primeiras missas foram celebradas no início do século XX. Ao largo da capela fica uma pequena praça onde costumam acontecer as festividades religiosas e a apresentação do grupo de congada. É uma capela bastante pequena, construída de um modo muito semelhante às igrejas em estilo colonial, muito comuns no interior de Minas Gerais. 


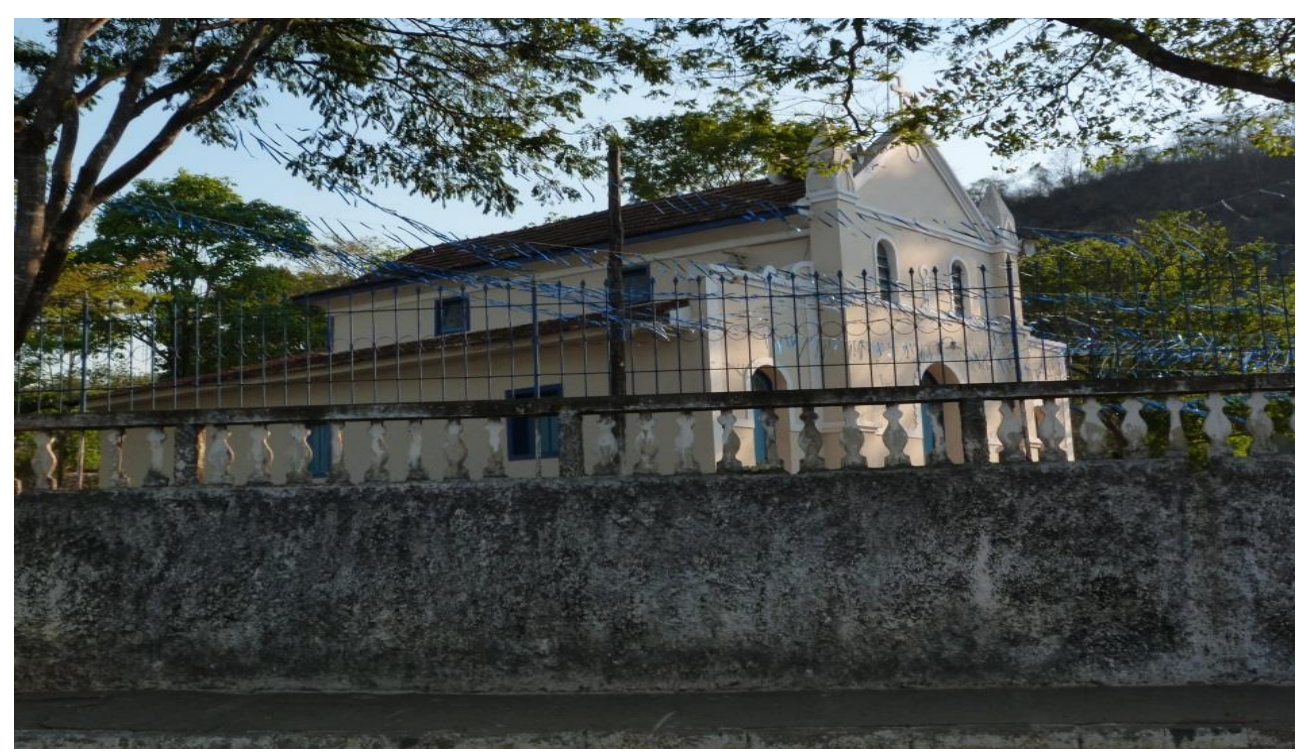

Figura 3 - Capela de Nossa Senhora do Rosário, em Pinhões-MG

Boa parte da população jovem de Pinhões acaba procurando trabalho em outros lugares, como Santa Luzia e Belo Horizonte, por causa da dificuldade de encontrar trabalho no vilarejo. Não há muitas oportunidades de trabalho formal em Pinhões. Desse modo, muitos jovens acabam mesmo se mudando e construindo sua vida fora da comunidade. Esse é um dos motivos para, segundo os moradores, haver diminuído o número de participantes no grupo de congada, que já chegou a ter mais de cem pessoas integrando-o.

Com o passar dos anos, pessoas sem laços de parentesco com as que já formavam a comunidade passaram a viver ali. A proximidade com as cidades vizinhas e a melhoria do transporte atraiu novos moradores. Uma grande quantidade de cristãos evangélicos também convive atualmente com a população católica de Pinhões. Pessoas que nasceram na comunidade e outras que passaram a viver ali, oriundos de outros lugares, levaram para o vilarejo igrejas evangélicas. Uma das reclamações que aparecem na fala dos mestres e da nossa anfitriã na comunidade é que surgiram algumas igrejas evangélicas e que o discurso delas provocava, às vezes, a mudança de igreja por parte das pessoas que antes eram católicas e participavam ativamente das atividades ligadas à congada e às festividade ligadas ao calendário litúrgico. 


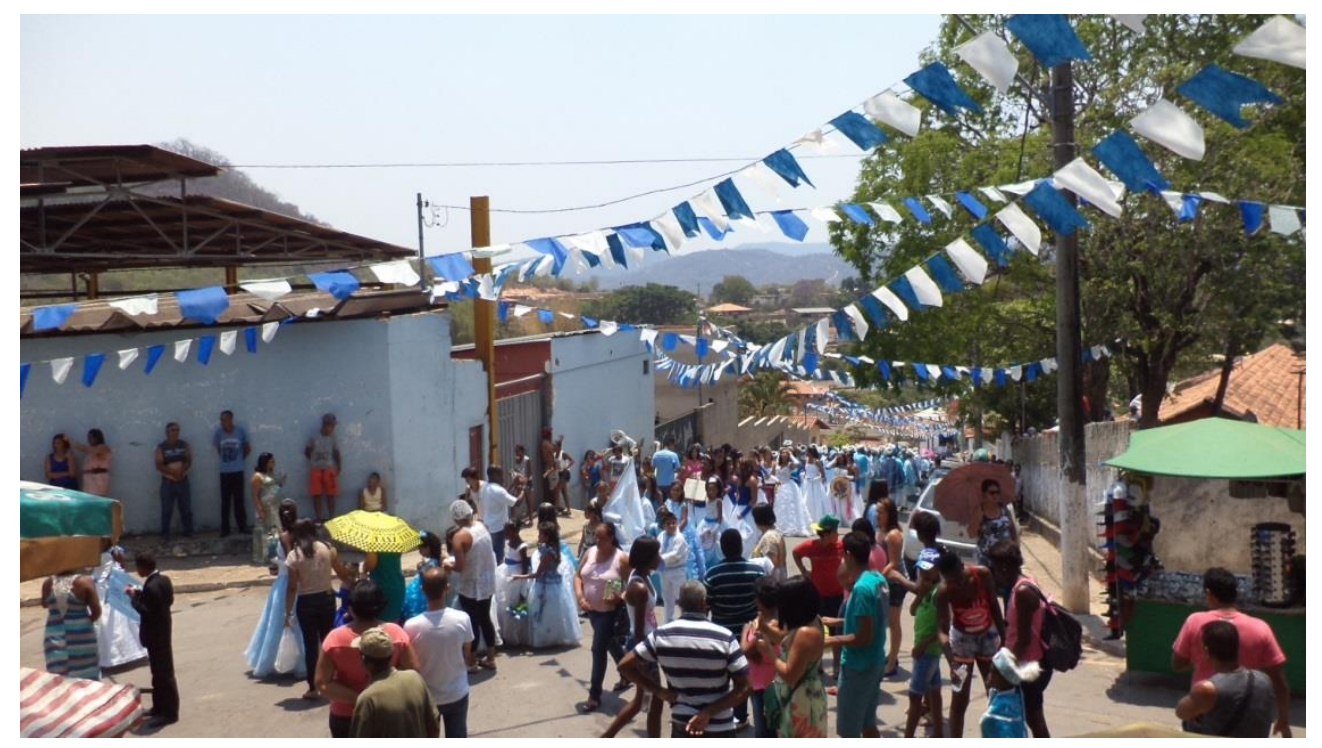

Figura 4 - Festa de Nossa Senhora do Rosário, em 19 de outubro de 2014

As modificações trazidas pela inserção de novos membros são vistas com pesar no que se refere ao aspecto de empobrecimento da participação comunitária nas atividades consideradas tradicionais pela comunidade de Pinhões. De qualquer modo, ainda há um grande grupo de católicos que participa da festa de Nossa Senhora do Rosário, ocupando as ruas e acompanhando a passagem do grupo de congada.

\subsection{O grupo de congada de Pinhões}

Do grupo de congada de Pinhões, participam apenas homens. De acordo com as informações coletadas junto a MG e aos mestres $\mathrm{A}$ e $\mathrm{B}^{15}$, desde a fundação do grupo por dois moradores há cerca de sessenta anos, aos homens cabia formar a guarda de Nossa Senhora, e às mulheres, cuidar dos demais preparativos da festa relacionados à preparação da comida servida aos participantes. As mulheres também aparecem compondo a corte do rei e da rainha, que são renovados a cada ano.

O grupo é composto por homens de todas as idades. Há crianças ainda bem pequenas e idosos, que por vezes nem conseguem mais acompanhar o ritmo do grupo ao subir as ladeiras do vilarejo cantando e dançando em homenagem à padroeira.

\footnotetext{
15 Dentro da pesquisa de campo foi feita uma omissão proposital dos nomes dos dois mestres, da moradora da comunidade e dos cinco jovens entrevistados, que foram substituídos por letras, o que ficará mais claro a seguir.
} 


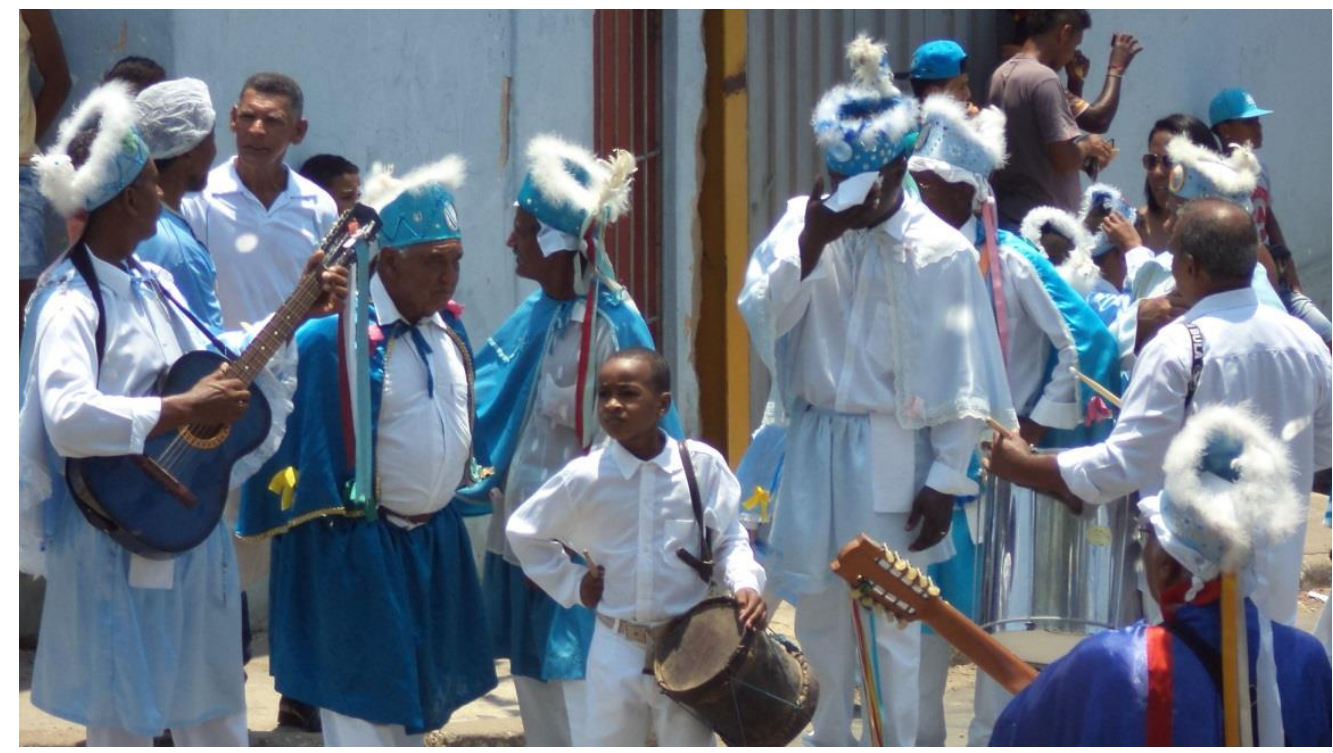

Figura 5 - Grupo de congado organizando sua formação

As caixas e violas enfeitadas nas mesmas cores em que as roupas do grupo são confeccionadas, o branco e o azul claro, marcam o ritmo dos cânticos e da dança. Organizamse em duas filas nas quais os mestres vêm à frente e os mais novos ficam atrás, como para simbolizar que uma longa caminhada foi trilhada pelos mais velhos até chegarem à condição de mestre. São diferentes gerações mantendo viva a tradição local, que está ancorada na devoção a Nossa Senhora do Rosário.

Todos os anos, o grupo se apresenta na festa da padroeira, mas essa não é a única atividade da qual participam. Ao longo do ano, há festividades católicas nas cidades vizinhas, oportunidade em que os grupos de congada e folia da região se encontram e confraternizam.

Durante os ensaios e as apresentações, há uma intensa movimentação e interação das pessoas que integram o grupo. $\mathrm{O}$ som da caixa e da viola, associado às vozes dos mestres e do coro que responde às invocações, ressoam pelas ruas e emociona a quem vê. É difícil descrever a sensação desse som invadindo o interior das pessoas e colocando-as em alerta, envolvendo-as em uma atmosfera de festa e devoção. A emoção que toma conta das pessoas é indescritível.

A apresentação do grupo observado ocorre no dia da festa de Nossa Senhora do Rosário. O vilarejo fica todo enfeitado com bandeirolas de papel de seda e laminado azul e branco. $\mathrm{O}$ grupo se concentra nas proximidades da casa do rei e da rainha, que se encontram vestidos elegantemente junto com sua corte e à espera de seus visitantes. Em seguida o grupo 
de congado, ao som das violas e caixas, segue com a corte até a capela, onde é celebrada uma missa, e a bandeira da padroeira é hasteada.

É importante destacar o fato de que diferentes gerações participam dessa festividade e integram o grupo de congada. Mesmo diante de todas as mudanças trazidas pelo tempo e pela inserção de novos membros à comunidade, bem como pela proximidade de Pinhões com relação a uma grande metrópole, ainda assim permanecem mantendo sua fé, suas festas e a essência de sua cultura.

\subsection{Conhecendo o grupo de jovens}

Para dar conta de responder aos objetivos propostos no início deste trabalho, partiu-se para a escuta de alguns jovens representantes da congada e da comunidade de Pinhões. Encontrar jovens que tivessem a disponibilidade para uma entrevista não foi uma tarefa muito fácil. A timidez dos jovens, seus horários de trabalho e estudo e suas atividades cotidianas nem sempre lhes permitiam reunirem-se em grupo com a finalidade de responder às perguntas que propostas.

Para que fosse possível ouvir bem o que cada participante dizia e identificar cada uma das respostas de maneira clara, foi delimitado um número máximo de cinco participantes. Um número maior poderia dificultar a audição e prejudicar a transcrição das falas, empobrecendo a coleta de informações.

Com a ajuda de $\mathrm{MG}$ e do mestre $\mathrm{B}$, encontramos cinco jovens dispostos a participar da entrevista em um dia de domingo, à tarde. O local marcado para o encontro e a realização do grupo foi a praça em frente à capela, um lugar acessível a todos e de fácil localização. No horário combinado, os cinco jovens apareceram, uns a pé, outros de motocicleta. Formavam um grupo com idade entre 13 e 25 anos. Ao longo da análise proposta, foram dados nomes fictícios aos jovens, nomeados como A, B, C, D e E, a fim de se diferenciar as falas de cada um deles. De acordo com a ordem das letras, seguem-se as idades $(25,18,15,15,13)$, respectivamente.

Houve uma conversa inicial na qual foi feita uma apresentação e cada um contou um pouco de sua história. Quatro dos jovens havia nascido e crescido em Pinhões. O outro, mais novo do grupo, contou que nasceu e passou a infância em Belo Horizonte e depois voltou com 
a família para o vilarejo, onde tinham parentes. Os dois mais velhos do grupo já haviam terminado o Ensino Médio e agora trabalhavam, respectivamente, como ajudante de marceneiro e ajudante de pintor. Os três mais jovens, por sua vez, disseram estar apenas estudando.

Essas informações preparam o caminho para a análise dos dados coletados, das falas do jovem com relação ao seu cotidiano e à sua participação no grupo de congada e dos processos educativos que ocorrem nesse contexto. As perguntas iniciais acabaram se desdobrando durante a realização da entrevista com o grupo, uma vez que novos e interessantes assuntos foram surgindo associados aos que foram introduzidos pelas primeiras questões formuladas. O resultado da nossa coleta de dados é o que está posto nas categorias e subcategorias que serão desenvolvidas a seguir.

\subsection{O caminho da pesquisa}

Conhecer a realidade de outras pessoas por meio de suas falas e da observação e interpretação não é uma tarefa fácil; está imersa em dúvidas e preocupações sobre a capacidade de compreender o mundo por meio de outros olhares que não o nosso próprio. De qualquer modo, acredita-se aqui que a convivência anterior nessa comunidade pode facilitar o entendimento sobre o que possa estar implícito na fala das pessoas entrevistadas.

Foram elaboradas algumas perguntas prévias a fim de servirem de parâmetro para a realização de um grupo focal com alguns jovens da comunidade. As questões começavam com um pedido de apresentação, para que cada um dissesse o nome, a idade, se trabalhava ou estudava, tempo de participação no grupo de congada. Seguiram-se então questões sobre o que é ser jovem, o motivo de participação na congada, como haviam ingressado nela, por que permaneciam, como era sua relação com os mais velhos e com os mestres, o que aprendiam na convivência com as pessoas do grupo, se sabiam como era o ritual da festa e sua história na comunidade, como eles viam a participação dos jovens, se percebiam alguma expectativa dos mais velhos com relação à participação dos jovens, como era a relação das pessoas na comunidade, como eles viam a questão de Pinhões ser um remanescente de quilombo, se havia outras festas na comunidade e nas regiões vizinhas e se participavam delas também.

Para a conversa com os dois mestres, a quem chamamos de mestre A e mestre B, e com a moradora da comunidade, a quem daremos o nome fictício de MG, foi elaborada uma 
entrevista semiestruturada, com perguntas a respeito dos jovens da comunidade que participavam da congada. Quem são os jovens que participam da congada? Com o que eles se ocupam (estudam, trabalham)? Nasceram por aqui? Como eles ingressam para o grupo de congada? Como vocês se relacionam com eles? Vocês ensinam algo a eles? Como ensinam? O que esperam deles com relação ao grupo de congada? Essas foram as perguntas iniciais, que acabaram se desdobrando em outros assuntos, levantados pelos próprios entrevistados.

O passo seguinte foi entrar em contato com $\mathrm{MG}$, pessoa bastante conhecida na comunidade. Ela nos recebeu e ajudou a entrar em contato com as pessoas que poderiam participar da coleta de dados. Foram feitas três visitas à comunidade. Uma primeira para articular com MG como faríamos para falar com as pessoas da comunidade, outra para conversar com os mestres da congada e uma última para falar com os jovens e registrar sua participação na festa de Nossa Senhora do Rosário, que ocorreria no dia dezenove de outubro.

Uma vez em contato com MG, fomos até a casa dos dois mestres, que conversaram um pouco sobre sua história de vida na comunidade e sua relação com a congada. Os mestres entrevistados são pessoas já idosas. Um deles, o mestre A, encontra-se com 87 anos e já não enxerga e escuta bem. A eles foram direcionadas perguntas sobre o que é ser jovem, sobre a história do grupo de congada, o funcionamento da festa, a sua participação no grupo e também a respeito da participação dos jovens nessas atividades.

Ao mesmo tempo em que foram coletados dados com gravação de áudio e vídeo, no qual registramos as conversas com os mestres A e B e com MG, passamos também a observar o cotidiano da comunidade, a rotina das pessoas, seu modo de proceder. Durante a festa de Nossa Senhora do Rosário, foi feito também um registro fotográfico do que acontecia. A observação nos trouxe importantes informações acerca da relação das pessoas entre si na vida comunitária.

A fala das pessoas e nossa observação, acreditamos aqui, trazem informações riquíssimas a respeito de seu modo de estar no mundo e de enxergar a realidade. Dessa forma, será feita uma triangulação entre as entrevistas com os adultos, o grupo focal feito com os jovens e a observação para coletar os dados. Acreditamos que a "observação permite ao pesquisador descobrir como algo efetivamente funciona e ocorre" (FLICK, 2009, p. 203), abrindo a possibilidade de por vezes confrontar o que foi dito nas entrevistas com os acontecimentos observáveis. 
Por meio daquilo que foi dito e observado, construímos um pequeno conjunto de ideias, um recorte daquele universo em um momento específico. Esperamos com essa ação poder contribuir para a compreensão dos processos educativos que estão presentes no cotidiano, no âmbito da cultura como fazer humano, e assim oferecer pistas que contribuam para uma visão ampliada sobre educação.

\subsection{Jovens da congada de Pinhões: Quem são? Por que são?}

A primeira categoria de análise estabelecida trata da condição de juventude. Quem é o jovem da comunidade de Pinhões que participa do grupo de congada? Essa foi uma pergunta lançada aos mestres e aos próprios jovens. É importante compreender do ponto de vista de quem está dentro desse contexto cultural os parâmetros conscientes ou não que definem e diferenciam os jovens dos adultos, uma vez que os processos educativos passam em grande medida pelo papel que cada um desses grupos de pessoas exerce.

De modo geral, os mestres da congada e os jovens que participaram da entrevista responderam de modo muito semelhante ao que foi questionado. Questões como a idade, o local de nascimento e de criação, o término dos estudos, a construção de uma família pelo casamento e a vida independente com relação aos pais se repetiram.

As respostas, então, foram agrupadas para facilitar e deram origem às seguintes subcategorias: o jovem sob o olhar dos mestres, o jovem por ele mesmo e, por fim, o jovem segundo o meio em que vive.

A ideia de uma delimitação etária definindo cada fase da vida, o que Peralva denominou "idades da vida" (2007, p. 13), está fortemente presente na mentalidade das pessoas ainda que de forma implícita. Foi a primeira informação que apareceu nas respostas daqueles que participaram da nossa coleta de dados. Foi relevante também nas respostas a questão geracional, segundo a qual o jovem é aquele que compõe as novas gerações. Por fim, destacou-se também a ideia de que o jovem é aquele que traz renovação.

\subsubsection{As gerações depois da nossa}

Ao serem questionados sobre quem são os jovens que participam da congada, os dois mestres responderam algo bem semelhante. $\mathrm{O}$ mestre A respondeu que 
Os jovens são a geração depois da nossa e assim por diante.

O mestre B, por sua vez, informou que compreende os jovens como sendo

Aqueles que vieram e que virão depois da gente.

Pelas falas acima, é possível notar que, na mentalidade dos mestres, a questão geracional é o que marca a diferença entre eles que são adultos e os mais jovens. Cada nova geração traz essa ideia de sucessão dos papéis desempenhados pelos adultos, pelos mais velhos na comunidade. Não houve menção durante a entrevista entre juventude, adolescência e infância, mas apenas uma alusão aos que nasceram depois dos mestres entrevistados. O jovem, nesse sentido, poderia ser qualquer um que tivesse nascido posteriormente.

Outra resposta bastante relevante que se seguiu à primeira foi aquela na qual o mestre $\mathrm{B}$, ainda se referindo ao que é ser jovem, afirmou que

Eles são como uma força nova pra comunidade.

A fala do mestre B leva-nos a compreender que os jovens muitas vezes são vistos como portadores de uma força vital que lhes permite levar adiante as atividades existentes no cotidiano da comunidade. No contexto de nossa pesquisa, é compreensível que o mestre atribua aos jovens a característica da força, uma vez que ambos os mestres são pessoas já idosas, com dificuldade para se locomover e tocar suas atividades adiante.

O mestre B ressaltou ainda, dentro da mesma pergunta lançada sobre o que é ser jovem, que

\section{O jovem é ele que traz a renovação pro mundo.}

A noção de que o jovem é capaz de trazer mudança com suas ações também apareceu em diferentes momentos da entrevista. A cada nova geração, a realidade se renova e vai ganhando outro rosto, outras características. Esse é um dos fenômenos que trataremos mais à frente ao falarmos da inserção de jovens e adultos na cultura. 
Essas contribuições dos mestres foram ao encontro do nosso desejo de conhecer o que os adultos pensam sobre quem é o jovem e o papel que atribuem a ele. Compreender a visão dos adultos sobre a juventude em Pinhões é um importante passo no sentido de identificar o que se espera do jovem nesse contexto. Nessa direção, o passo seguinte é observar como o jovem define a si mesmo.

\subsubsection{O olhar do jovem sobre si}

Quando questionados sobre a sua condição de juventude, os participantes do nosso grupo focal levantaram alguns pontos que convergiram entre si, como o fato de viverem ainda na casa de seus pais, de estarem trabalhando na condição de aprendizes ou apenas estudando e de não terem ainda constituído sua própria família. As respostas foram organizadas do jovem A ao E a fim de facilitar a nossa análise.

Quando a pergunta "O que é ser jovem para vocês?" foi lançada, os participantes do grupo olharam entre si, sorriram, e o jovem A começou respondendo

Eu acho que ser jovem para mim é não ser adulto (riso) estar morando ainda com meus pais. É não ter ainda a responsabilidade da vida que nem eles.

Por sua vez, o jovem B respondeu

Acho que a gente só vai ser adulto mesmo quando tiver nossa casa, filhos.

Diante das respostas dadas, entrei então com outra pergunta: "E vocês não tem suas responsabilidades também?”. Eles responderam afirmativamente. O jovem E então completou dizendo

A minha responsabilidade hoje é com a escola e ajudar minha mãe em casa.

O jovem A deu continuidade à questão lançada respondendo

A gente tem nossa responsabilidade sim. Eu por exemplo trabalho de aprendiz de marceneiro e dá pra me virar com o que eu ganho. Faço minhas coisas que eu preciso, ajudo em casa e tudo. Mas é diferente de adulto, a responsabilidade deles eu acho que é maior. 
As respostas dadas nos remetem a dois pontos trabalhados na revisão de literatura sobre juventude, a saber a questão da inserção nas regras sociais levantada por Groppo (2000) e a assunção de papéis adultos mencionada por Abramo (2007). O ingresso na vida adulta muitas vezes passa pelo fato de se estar imerso ou não nas regras sociais, e quando os jovens destacam que ainda não têm responsabilidades semelhantes às dos adultos, podemos inferir que eles se consideram ainda isentos de cumprir determinados papéis que aos adultos são obrigatórios, ainda que nem sempre sejam cumpridos por estes. Do mesmo modo, ser dependente, não ter constituído família, não ter sua própria casa dá aos jovens entrevistados a ideia de que não assumiram ainda a posição de pessoas adultas.

Cada sociedade possui suas regras e suas condições para definir quem são os adultos e quem são os jovens. De modo geral, há um padrão que marca a passagem para a vida adulta, que está relacionado com a independência financeira e o abandono da casa dos pais, quer seja para constituir sua própria família quer seja apenas para se desvencilhar do seu lar anterior, ganhando, com isso, novo status.

As questões ligadas ao meio onde vivem os jovens também são relevantes para definir sua passagem para a condição de adultos. Viver no campo ou na cidade, ter acesso à educação formal ou não, ter ou não oportunidade de ingressar em uma atividade remunerada desde cedo estão entre os fatores que definem quando e de que modo os jovens deixarão sua situação anterior para passar ao universo dos adultos.

\subsubsection{O jovem segundo o meio em que vive}

Para compreender o meio em que estão inseridos os jovens que participaram do grupo, levamos em consideração aquilo que eles próprios aludiram em suas falas, o que foi dito pelos mestres e também o que observamos durante a estadia na comunidade.

Conforme já foi mencionado, Pinhões é uma comunidade rural, que fica a cerca de quinze quilômetros de Santa Luzia, região metropolitana de Belo Horizonte - MG. Muitas pessoas vivem do que extraem da terra ou da produção artesanal de doces e vasilhas de cerâmica. Outras tantas procuram trabalho nas cidades vizinhas, dedicando-se às mais variadas atividades. $\mathrm{O}$ vilarejo e seus arredores não oferecem atualmente condições para que a população permaneça trabalhando ali. A saída para os jovens muitas vezes é trabalhar como 
aprendizes em profissões diversas, prestar serviços nas fazendas vizinhas ou manter-se em atividades informais no comércio local e nas cidades próximas.

Uma das queixas do mestre A com relação aos jovens que deixam a comunidade e o grupo de congada está associada às condições de trabalho encontradas na comunidade. Ele afirma que

Tem muito jovem que deixa aqui e vai viver fora procurando trabalho.

As condições de sobrevivência por meio do trabalho, então, acabam por definir que o jovem é aquele que está na condição de informalidade, como aprendiz, ou que deixa a comunidade para procurar melhores oportunidades fora daquele que é seu espaço.

A conquista de uma renda própria pelo trabalho, por sua vez, está vinculada à questão da dependência do jovem com relação à família. Não ter um emprego formal e não ser capaz de cuidar de si sem a ajuda financeira de outros contribuem para a permanência na condição de jovem, pois, segundo afirma o jovem $\mathrm{C}$,

Para mim a gente é adulto só quando já tem emprego e se vira sozinho, sem precisar dos pais.

Fazer parte da comunidade de Pinhões, sob as condições que se desenham pelas características do lugar, é, desse modo, um aspecto a ser considerado em se tratando de compreender como os adultos enxergam o jovem e como ele próprio se vê. A questão etária, que muitas vezes é utilizada para definir a juventude quando posta em confronto com o que se observa em uma comunidade como a de Pinhões, que tem características singulares, é de fato bastante relativa, em consonância com o que foi mencionado por Groppo (2000, p. 10). A idade é apenas um dos fatores levados em consideração para se compreender quem é o jovem naquele contexto.

\subsection{Diferentes modos de inserção na cultura}

A segunda categoria estabelecida trata do modo como adultos e jovens se inserem na cultura de Pinhões ligada à congada e à devoção a Nossa Senhora do Rosário. Vale destacar que foram eleitos esses elementos da cultura local para observar neles os processos educativos 
que porventura ocorressem envolvendo adultos e jovens. Dos eventos singulares, partiu-se para enxergar algo maior (GEERTZ, 1989). Da participação dessas pessoas em uma das mais importantes atividades culturais da comunidade, pretendemos extrair informações relativas ao modo de se educar as novas gerações, observando as características dessas práticas educativas.

É importante também ressaltar que as pessoas participam de sua cultura de modos diferentes e que sua participação é limitada, pois engloba alguns aspectos e deixa outros de fora. Assim, não esperamos encontrar uniformidade nas respostas lançadas nessa categoria, mas visões distintas sobre um mesmo ponto em discussão (LARAIA, 2009).

As perguntas lançadas aos mestres giraram em torno da participação deles próprios e dos jovens no grupo de congada: se havia muita diferença entre a época em que entraram para o grupo e o momento atual (e no caso de haver diferenças, quais seriam elas). Aos jovens foi perguntado como entraram para o grupo, por que participavam da congada e como eles viam sua própria participação.

As respostas giraram em torno da ideia de que cada um interage com a realidade cultural à sua volta por razões específicas e permanece nessa interação também por motivos diversos. Já com relação à mutabilidade da cultura, que aqui tomamos como as mudanças introduzidas pelas novas gerações no grupo de congado e seu modo de proceder, tanto os mestres como os jovens identificaram pontos negativos. Em suas falas aparecem informações sobre o modo como era no passado, nos primeiros anos de existência do grupo, e o modo como atualmente tem sido a participação das pessoas, dando a entender que algo havia se perdido com o passar do tempo.

\subsubsection{Por que o jovem participa?}

Quando questionado sobre o motivo que levava os jovens a participarem do grupo de congada, o mestre A informou

O que traz os meninos novos para o grupo é a fé em Nossa Senhora. É um chamado.

Em resposta à mesma pergunta, a saber, o motivo pelo qual os jovens participam do grupo de congada, mestre $\mathrm{B}$ respondeu 
O Catopé como outras guardas... tá vivo hoje pela ação de graças. Por que ação de graças? Porque tem um compromisso, quando você vai entrar na guarda, é um compromisso de sete anos, um compromisso que você faz com Deus. Ação de graças também porque uma mãe às vezes faz promessa para um filho ou a própria pessoa faz e ela chega e fica e aquilo enraíza nela. Eu vou fazer 36 anos (na congada).

A religiosidade, que é um dos elementos tradicionais na congada, faz-se presente na motivação para que os jovens ingressem no grupo. Muitas famílias fazem promessas, ou os próprios jovens as fazem com objetivos ligados às questões de saúde, trabalho, entre tantas outras, e como forma de pagar tais promessas ingressam na guarda (no grupo de congada). A devoção e a espiritualidade se mostraram presentes em diversos trechos das falas tanto dos mestres como dos jovens.

Os próprios mestres, por serem também cristãos católicos, têm sua entrada no grupo de congada marcada pela fé. Mestre A destacou

A gente entrou com o compromisso de cumprir uma promessa. Uma promessa nossa e de nosso parceiro, nossa dupla, de pelo menos sete anos. Cada um que entrava tinha que formar o compromisso e levar adiante com a pessoa que dançava com ele. Tinha que manter firme dançando pra ela (Nossa Senhora do Rosário). A gente se diverte na fé.

O mestre B, por sua vez, sobre a escolha de entrar ou não entrar para o grupo, afirmou

A gente não escolhe, a gente é escolhido por Deus.

Os mestres entendem que sua participação, bem como a de qualquer pessoa que entre para o grupo, está ligada a uma escolha divina daqueles que farão, durante algum tempo (mas esperam que seja por toda a vida), parte da guarda de Nossa Senhora do Rosário, dançando e cantando em homenagem a ela. Eles não veem o ingresso como algo que depende da vontade das próprias pessoas, mas dos desígnios de Deus. A fé aparece como característica mais marcante em sua fala.

\subsubsection{Por que eu, jovem, participo?}

Os jovens, quando questionados sobre seu ingresso no grupo de congada, informaram motivos diferentes, mas muitos ligados também à religião, à fé. O jovem A respondeu: 
Eu participo por conta do meu avô que era violeiro, aí meu padrinho por parte da minha mãe já dançava, aí veio meu primo mais velho, aí depois veio eu, que é mais é por conta de família mesmo. Todo mundo da minha família assim, primos, tios, todo mundo participa. Pra mim também foi um marco na minha vida também, de um acidente que eu tive, eu tenho pra mim que foi ela (Nossa Senhora do Rosário) lá em cima que me salvou, por isso que eu danço para ela, com muita fé (emocionado) e nada mais me importa. Foi um acidente de bicicleta. Seis para sete anos de idade eu fiquei sessenta e quatro dias em coma, mais trinta e sete dias no CTI, mais trinta e dois dias no quarto. Eu tenho pra mim que foi ela que me salvou, ela disse que não era hora de eu partir dessa pra uma melhor. Por isso eu danço pra ela todo ano, com fé, eu falto de serviço pra dançar pra ela. Eu nunca deixei de ir na festa dela pra trabalhar, pra nada. Por nada nessa vida eu deixo de dançar pra ela, no dia dela é só pra ela. Eu venho, meu dia de sábado e domingo é determinado só pra ela. Eu desmarco tudo que tiver marcado, mas o dia dela é só pra ela, pra mais ninguém. Pra mim é assim porque ela é minha terceira mãe, minha padroeira, tudo que eu peço pra ela, pode demorar um pouco, mas sempre eu consigo, sempre que eu peço com fé eu consigo o que eu pedi. Eu peço pra ela e ela realiza os meus desejos todos. Por isso sempre, em toda minha vida, enquanto eu estiver vivo eu vou dançar pra ela.

\section{O jovem B informou}

Pra mim foi mais pela fé também. A maioria da minha família, meus primos tudo dança também, entendeu? Aí veio na minha cabeça que no dia dela eu necessito dançar, entendeu? Tem que vir mesmo. Até eles mesmos já tinham chamado (os parentes) e teve um ano aí que eu vim e tô até hoje.

O jovem C, por sua vez, disse

Eu mais é porque a família participava já aí eu... até hoje eu tô dançando pra ela. E se Deus quiser eu vou continuar dançando. E também eu tô dançando para servir ela. Eu e meu irmão caímos de moto e até hoje ele não tá mexendo o braço direito, ai eu rezo todo dia pra que ele volte a mexer o braço. Tem muita gente que entra pra pagar promessa, faz uma promessa e aí entra pra pagar.

Já o jovem D afirmou

Eu comecei a dançar por causa do meu pai, que quando eu era pequenininho eu era muito agarrado nele e ele me levava todo ano. Ele me deu a farda e eu danço até hoje. Não foi promessa, foi só porque eu quis mesmo.

O jovem E, por fim, informou sobre sua participação

Eu é porque cheguei aqui uma época, aí era a época que estava dançando, aí eu perguntei pro meu primo, o que que é isso? Aí ele me falou e eu falei: a partir do ano que vem eu vou começar a dançar, aí eles foi me ensinando, aí no outro ano eu fui pra frente, aí daí pra frente eu danço. Antes eu morava em Belo Horizonte, eu mudei pra cá tem três anos. 
Nas falas dos jovens, é possível notar alguns elementos que se repetem. Um deles refere-se à fé. A maior parte das famílias de Pinhões é católica. A religião é uma constante em sua cultura local há muitas gerações. As famílias envolvem-se com a congada, e os mais jovens, por nascerem e crescerem nesse meio, acabam absorvendo a crença dos pais e parentes e colocando em prática ações ligadas à fé. Eles utilizam expressões como "foi pela fé", "muita gente entra para pagar promessa" ou ainda "tenho pra mim que ela me curou", que refletem seu envolvimento com as questões religiosas que fazem parte do cotidiano no qual estão imersos.

O jovem E, que vivia em uma grande cidade e se mudou com a família para Pinhões há cerca de três anos, passou a conhecer a congada e a fé de seus parentes a partir desse contato mais próximo. Contou que sua realidade era outra, que frequentava uma igreja evangélica com a avó. Chegou ao vilarejo em época de apresentação da congada e, por convite dos primos que têm aproximadamente a mesma idade que ele, decidiu participar do grupo e aprender o que era necessário para permanecer nele e poder se apresentar nos dias de festa.

Observou-se que, mesmo estando em outro contexto cultural, os familiares do jovem $\mathrm{E}$ já haviam falado das tradições existentes em seu lugar de origem. Ao entrar em contato com tais tradições e presenciar a participação de seus parentes, animou-se também a fazer parte desse novo (para ele) e antigo (para seus familiares) ambiente cultural.

O depoimento do jovem E chamou atenção para o fato de que os jovens se atraem mutuamente. Questões ligadas à festa, ao riso, à animação, que muitas vezes fazem parte do contexto juvenil, são fatores determinantes no seu ingresso em determinada atividade. $\mathrm{O}$ mesmo ocorre com o grupo de congada. O movimento, a agitação, a diversão, aliados a outros motivadores como a fé, as promessas e a tradição presente na manifestação cultural, atraem os jovens a participar. A presença de outros jovens, amigos, primos etc. e a visibilidade que o grupo de congada tem na região se mostraram também como um fator de atração para os meninos entrevistados.

As informações encontradas na fala dos jovens e também as coletadas por meio de nossa observação permitem que sejam identificados seus modos de sociabilização e também algumas regras de sua conduta que estão relacionadas ao ambiente em que vivem. É importante considerar que "estudar a cultura é, portanto, estudar um código de símbolos 
partilhados pelos membros dessa cultura" (LARAIA, 2009, p. 62-63). Desse modo, tanto a religiosidade, que é herança das gerações passadas, quanto a sociabilidade e a visibilidade que se tem estando no grupo, que se apresenta dentro e fora da comunidade ao longo de todo o ano, são fatores importantes para os jovens entrevistados.

\subsection{Práticas educativas na cultura}

Neste trabalho a educação foi tratada como práticas educativas, algo que existe desde os primórdios da humanidade, com a cultura. Acredita-se aqui que um objetivo primordial das pessoas em educar as gerações mais jovens é o de preservar o legado humano, encaminhandoo para o futuro, é não deixar que os aspectos culturais já desenvolvidos se percam. O que foi construído no passado é algo valioso, uma herança, que precisa e merece ser preservada.

Tais práticas educativas podem ainda hoje ser observadas em sua essência, naquilo que a caracterizava antes do surgimento da educação escolarizada. A transmissão oral, a imitação do exemplo, a inserção dos mais jovens na condição de aprendizes com os mais velhos. Esses são modos muito antigos de se educar. Passam pelo reconhecimento e respeito com relação às pessoas mais velhas, mais experientes. Estão fundamentados na transmissão de conteúdos fortemente vinculados ao cotidiano, às características culturais de um povo ou de uma comunidade.

Pod-se ainda dizer que tais práticas educativas passam pela liberdade e pela vontade de todos os que nelas estão envolvidos. Não há como se ter um controle, emitir pareceres ou certificados em uma educação como essa. Ela é feita ao ar livre, fora dos muros das instituições, no âmbito da própria vida. A congada, nesse sentido, serviu como ponto para forcar a observação, foi um pequeno, porém importante detalhe do universo cultural do povo de Pinhões.

Nesse ambiente, onde estão presentes elementos culturais ligados à fé e à devoção das pessoas negras, elementos estes que existem no Brasil há séculos e há décadas dentro da comunidade, foi possível compreender um pouco sobre o modo como aquelas pessoas educam seus jovens e o que elas esperam das gerações futuras. Observou-se também o modo como os próprios jovens se viam dentro desse contexto. A relação entre os mais velhos e os mais moços está envolta na confiança, no acolhimento e no respeito pelas diferenças, em uma 
convivência de pessoas que se reconhecem como pertencentes a um mesmo lugar, a uma mesma cultura. Aquele é seu espaço comum.

O que os jovens aprendem? Com quem? De que modo? Essas foram perguntas lançadas aos jovens que participam do grupo, referindo-se ao que eles aprendiam com as pessoas da comunidade, dentro e fora do grupo de congada. Entre suas respostas surgiram a figura dos mestres e de seus familiares, que também participam da congada, e os amigos que fazem parte do grupo. O aprender, nesse sentido, ora se dava de modo casual, na relação entre as pessoas, ora ocorria maneira intencional. Nas rodas de conversa, nas visitas aos amigos, nas missas etc., muitas informações são trocadas entre pessoas de idades diversas. Por outro lado, a instrução para executar as atividades dentro da congada ou para exercer uma profissão ocorre de maneira explícita, e a intencionalidade é bem clara.

\subsubsection{O que e como se aprende?}

Nessa subcategoria, foi levado em consideração não apenas o que os jovens aprendiam para realizar as atividades da congada, mas tudo o que foi possível observar no dia a dia deles no pouco tempo de estadia na comunidade. É possível organizar o que foi observado em pelo menos três grupos de aprendizagens: aquelas que se referem à própria vida em família e na comunidade, como o respeito pelos mais velhos, o cuidado com a casa e consigo mesmos, o cuidado com os outros (um doente, um amigo), que são aprendizagens ligadas à sobrevivência, convivência e solidariedade; aquelas que se referem ao mundo do trabalho, no qual os jovens inserem-se como aprendizes ou ajudantes para, no futuro, poderem desempenhar as tarefas sozinhos; e, por fim, aquelas que se referem à congada, à fé e às tradições presentes na comunidade de Pinhões e na região.

No que se refere ao que os jovens aprendem para conduzirem a própria vida, destacar destaca-se a questão da ajuda mútua e da solidariedade, que está também ligada à proximidade existente entre as famílias, cujas bases se assentam na fé cristã. Quando perguntados a respeito da interação entre as pessoas da comunidade, o jovem A respondeu

Aqui é sempre um ajudando o outro né. Sempre tem algum doente, aí os mais velhos se juntam, fazem uma oração assim, pela enfermidade daquela pessoa. $E$ sempre assim, sempre foi assim. 
Com a observação ao longo dos três anos de convivência e nos dias coleta de os dados, foi possível perceber diversas vezes a ajuda mútua entre os vizinhos. Trata-se de uma comunidade bastante carente de recursos, então aquele que tem algo acaba dividindo com quem não tem nada.

As pessoas se visitam muito na comunidade, sentam-se juntas e tratam de assuntos diversos, dentre eles se há alguém doente ou necessitado de ajuda. Essas são situações que fazem parte da realidade dessa comunidade. E, nessa convivência, diversas experiências são trocadas acerca de uma infinidade de assuntos, como receitas, remédios, orações. As crianças crescem nesse ambiente e absorvem esse modo de estar no mundo, essa vida comunitária.

Com relação ao mundo do trabalho, os jovens inserem-se como aprendizes, observando e imitando o exemplo dos mais velhos, geralmente parentes ou amigos que já exercem alguma profissão. Desse modo, a maioria deles segue as profissões tradicionais na comunidade. Quando perguntados sobre o trabalho, o jovem A respondeu:

Sou ajudante de marceneiro. Eu não tenho hora para chegar em casa quando eu saio para montar móveis. Eu mexo com móveis. Aprendo tudo que sei com meus colegas de trabalho que já estão lá há mais tempo. No começo não foi muito fácil, mas depois a gente vai pegando o jeito.

O jovem B, por sua vez, disse

Sou ajudante de pintor. Tenho dezoito anos. Aprendi o que sei hoje com meu pai, que é pintor. Vejo ele trabalhar desde quando eu era moleque, aí pra não ficar à toa, sem dinheiro, eu quis aprender.

A realidade da comunidade de Pinhões com relação ao trabalho é que a maior parte dos jovens segue os passos de seus familiares e parentes para garantirem alguma fonte de renda. Dentro da comunidade há poucas oportunidades de emprego e muitas pessoas trabalham em Santa Luzia e Belo Horizonte, motivo pelo qual muitos jovens deixam Pinhões.

Com relação à participação na congada, os jovens conhecem todo o ciclo da festa e sabem o que é necessário aprender para participar de forma ativa das atividades propostas. Aprenderam também observando os mais velhos, parentes, amigos, mestres. Em resposta ao nosso questionamento sobre o modo como ocorria o ciclo da festa de Nossa Senhora do Rosário, evento que deu origem ao grupo de congada, o jovem B respondeu: 
Ela começa no domingo e termina na segunda. No domingo a gente busca o rei e a rainha na casa deles. Vem pra igreja, ouve a missa, aí dança, cumpre promessa aqui na igreja, aí tem a missa das três, aí anuncia o rei e a rainha do ano que vem, aí tem a procissão com os dançantes mais o pessoal, aí tem a benção final. Aí na segunda feira às dez horas da manhã tem a missa, aí depois o congado sai andando nas ruas de Pinhões todinhas, até chegar lá embaixo quando tem o encerramento da festa.

O jovem D completou o raciocínio iniciado pelo seu colega dizendo

Sempre antes de começar a dançar reúne todo mundo e faz uma oração pedindo a bênção de Nossa Senhora para dar força para todo mundo por que andar debaixo desse sol muita gente abre o bico, não aguenta, já aconteceu até de gente desmaiar por conta do sol, mas fora isso com a bênção dela todo mundo vai, pé doendo, pé dando bolha, mas vai assim mesmo.

Ao chegar então ao contexto da manifestação cultural da congada, será mantido o foco em um dos aspectos considerados muito relevantes: as falas dos mestres e dos jovens a respeito do que se aprende e como se aprende aquilo que faz parte das tradições presentes nesse ambiente, em comparação com o que acontecia no passado, nos primeiros anos de existência do grupo.

Quando perguntado ao mestre A como era a troca de saberes no tempo de sua juventude, ele informou:

Então quando eu comecei, ah meu Deus, era tão difícil, um dia eu fiz assim oh, eu olhei e tinha um barranco, eu olhei e sentei no barranco. O mestre olhou e falou assim: ô amigo, faça o favor, você está cansado? Eu disse: não. Então faça o favor, levanta, porque nós estamos em forma, nós somos soldados. Você não sabe disso não? Uma vez que a gente coloca a farda de Nossa Senhora no corpo nós somos soldados, somos polícia. Não faz isso mais não, se você está cansado não vem não. E aquilo pra mim foi a mesma coisa de terem passado a mão num chicote e ter metido o chicote.

$\mathrm{Na}$ época em que o mestre A havia ingressado no grupo de congada, os mestres e padres costumavam ser bastante rígidos quanto aos ensaios e às apresentações. O aprendizado dos jovens era feito sob a vigilância e as regras dos mais velhos. Quem quisesse fazer parte do grupo precisava fazer o mais fielmente possível aquilo que os mestres instruíam. Nas palavras do mestre A, quebrar as regras era uma ofensa a Nossa Senhora, e a vergonha era pior que qualquer punição que pudesse haver. 
Nesse sentido, nas palavras do mestre B, também aparecem referências a um passado em que a participação das pessoas mais jovens era feita dentro das regras, sem quebrar as tradições ligadas ao comportamento, aos modos de proceder dentro do grupo. Mencionando os acontecimentos do presente, ele afirma que alguns compromissos que existiam, como a participação nos ensaios para aprender a tocar os instrumentos e a cantar, foram desaparecendo. Ele afirma

\begin{abstract}
Muitas vezes a gente cobra deles (dos jovens) aprenderem a letra da música. Como que você vai ensinar se eles não vão aos ensaios? Aí eles (jovens) pedem assim: ah, passa a letra da música. Eu não concordo. Por quê? Pode ser que eu esteja errado, mas o procedimento é esse aí. Se a pessoa está interessada em aprender vai no ensaio. A gente começa a trabalhar a pessoa desde a participação dela. Outra coisa que eu não concordo é de hoje alguém te dar a roupa. Até políticos em época de campanha falam: vem aqui que eu vou te dar a roupa. A roupa faz parte da espiritualidade, a pessoa tem que fazer sua roupa. Já teve vezes de mestres não terem um calçado adequado, e isso foi verídico, e não poderem dançar e nem ficou aqui, atravessou para o outro lado do rio para não ouvir a congada cantar [...] naquela época não tinha um lugar apropriado (para os ensaios), não tinha um salão, era debaixo de um pé de manga. Eles (os mestres) tinham um prazer enorme de ensinar aquilo que eles tinham aprendido. Hoje as pessoas não querem confessar antes da festa, e isso era tradição, o grupo inteiro confessar, e as crianças para entrar tinham que fazer a primeira comunhão. Isso tudo mudou.
\end{abstract}

Os mestres tratam de várias mudanças que foram aparecendo ao longo do tempo. Afirmaram que marcam os ensaios e poucas pessoas comparecem, sobretudo os jovens. Tal constatação dos mestres está relacionada ao modo como os jovens aprendem aquilo que lhes interessa dentro da congada. Quando perguntados sobre o que aprendiam e como aprendiam, apenas um jovem, o A, disse conhecer as músicas, uma vez que seu pai é mestre. Os demais sabiam apenas os passos da dança. O jovem A afirmou

Para a maioria das pessoas mais jovens o importante é a dança, a música pra responder é muito difícil. Só aqueles que já estão há mais tempo que nem eu que estou há dezenove anos dançando. Tem gente que tem trinta, quarenta anos que puxa mais a resposta, são aqueles que ficam mais na frente. Mas o resto dos meninos mais novos é a dança mesmo, a agitação, aquele pique todo.

$\mathrm{O}$ pique, a agitação e a alegria mencionados pelo jovem $\mathrm{A}$ apareceram também nas falas entremeadas que seguiram. Ficou claro que para eles as festas e apresentações da congada passavam também pelas questões ligadas ao prazer e à diversão. Com o tempo, eles acabam aprendendo a cantar e a tocar algum instrumento. Mas, de modo geral, afirmaram que seu interesse maior estava na dança, no movimento. Quando perguntados sobre a 
aprendizagem da dança e dos passos e sobre a participação deles nos ensaios, os jovens responderam algo bem semelhante.

O jovem $\mathrm{B}$, a esse respeito, afirmou

As músicas eu não sei não. Pra mim é falta de atenção mesmo. Presto atenção na dança que é o que me interessa mais. Foi fácil aprender a dançar, aí é o costume né, você vai observando e aprende. É tanta atenção que a gente presta na dança que...

O jovem D, por sua vez, sobre o que aprendia e como aprendia no contexto da congada informou

Eu também não sei não (as músicas), mas dançar é só ir olhando que a gente aprende. Eu só vim nos ensaios no começo quando eu queria aprender a dançar, aí depois eu não fui mais não.

O jovem E, por fim, respondeu

Eu vim nos ensaios o ano passado, esse não. Aprendo com os meus primos mesmo, a gente se junta e treina os passos. A gente aprende mais é assim, com os amigos.

Os jovens acabam selecionando o que querem aprender e muitas vezes, em vez de participarem dos ensaios, aprendem observando seus amigos e parentes da mesma idade que já sabem dançar. De qualquer modo, dentro da congada, aqueles que não se interessam por determinadas atividades, como cantar ou tocar instrumentos, e querem se dedicar só à dança, encontram acolhimento e respeito por parte dos integrantes do grupo.

Há o desejo de que os mais jovens aprendam o que é necessário para não deixar a congada de Pinhões desaparecer com o tempo, mas o desejo de não fazer é respeitado. Por outro lado, os jovens reconhecem tais mudanças, apontam algumas como negativas, mas permanecem fazendo dentro do grupo apenas aquilo que realmente lhes interessa, participando a seu modo.

\subsection{Tradição, uma herança}

A tradição, algo que foi construído no passado e transmitido de geração a geração, sobretudo por meio da educação dos mais jovens, forma um conjunto de práticas, saberes e 
crenças, cuja importância e veracidade não carecem de comprovação para vigorarem e servirem de parâmetro para a vida de uma comunidade, um povo. Ela coincide com o que as gerações mais velhas querem deixar para as mais novas; aquilo que julgam necessário conservar, como seu passado e sua memória.

Esse legado evoca as origens, o começo de uma vida em comum, a construção da identidade de um grupo. Trata-se de uma herança que não pode ser acessada pelos jovens do mesmo modo como foi recebida. Segundo Hanna Arendt (2013, p. 40), “cada nova geração, e na verdade cada novo ser humano, inserindo-se entre um passado infinito e um futuro infinito, deve descobri-lo e, laboriosamente, pavimenta-lo de novo". As novas gerações recebem uma indicação do que foi o passado por meio dos adultos, mas terão de construir seu próprio caminho utilizando as informações que herdaram.

É certo que a figura do jovem está envolta, como já afirmado, nas ideias de conservação do passado ou transformação da sua realidade em algo novo. Acredita-se aqui que o jovem cumpre esses dois papéis ao mesmo tempo. Ao seu modo, o jovem recebe uma herança cultural e coloca-a em prática, dando a ela uma cara nova, compatível com sua visão de mundo, com a realidade que o cerca, que é diferente daquela em que seus antepassados viveram.

É comum o jovem ser encarado como aquele que trouxe mudanças não desejadas ao que já estava posto, como no caso do grupo de congada, mas o que ocorre é que ele muitas vezes não consegue e não precisa se relacionar com o passado do modo como se espera dele.

As ideias lançadas por Arendt ao tratar da tradição ligada à política décadas atrás pareceram, nesse contexto de investigação, bem atuais e respondem ao impasse: o jovem costuma ser educado para manter as características culturais de sua comunidade, seu povo, ou para transformá-la em algo novo quando necessário? Na verdade, ele cumpre esses dois papéis. Relaciona-se com o passado de um modo novo e imprime a ele características novas, porque sua visão de mundo é outra, diferente do modo como os que viveram no passado. Também aqueles que viveram no passado se relacionaram de modo diferente com o que herdaram de tempos remotos. Essa é a roda da vida.

\subsubsection{O que eu quero que você leve}


Nessa subcategoria, foi levada em consideração a fala dos mestres a respeito do que esperam das gerações mais jovens. Suas ideias giraram em torno de que eles já estão indo embora, "passando" (expressão do mestre B), e que os jovens irão assumir o lugar deles. Daí a importância de que participem dos ensaios, aprendam a fazer as diferentes vozes, saibam a letra das músicas, e participem do ritual presente na congada.

A respeito da importância da participação dos jovens nos ensaios e na aprendizagem dos elementos de dança, música e fé dentro da congada, o mestre A afirmou

É o seguinte, esse ano nós estamos aqui, ano que entra a gente não sabe se tá, então quem tem que assumir isso aqui é essa turminha nova [...] quando eu era jovem e tinha ensaio, vinha homem de tudo enquanto era jeito, de todo lugar, vinha de Macaúbas, de Santa Luzia, hoje é um custo aparecer alguém.

O mestre B, por sua vez, ao falar dos mestres e também dos jovens que fazem parte do grupo, disse:

Nós estamos numa aprendizagem. Se a gente aprendeu um pouco a mais para dar continuidade, nós somos discípulos de nossos antepassados. Então, se nós fomos escolhidos, é indiferente se você é adulto ou uma criança, se ela tem um dom e está lá na frente, é um discípulo, ele tá dando continuidade, porque amanhã nós vamos e vem mais gente. A gente tem que procurar fazer o certo e deixar o certo, porque daqui só levamos o nosso bom nome, o que fizemos de certo e de bom.

Transparecem nas falas dos dois mestres a preocupação de que a geração deles está acabando, morrendo, e por isso os jovens devem assumir o papel de levar adiante as tradições presentes na congada. Há uma preocupação de que os jovens participem dos encontros com os mais velhos e aprendam a cantar fazendo a diferenciação das vozes, saibam tocar os instrumentos (caixa e viola) e participem dos rituais que fazem parte da apresentação da congada na festa de Nossa Senhora do Rosário (como a obrigatoriedade da confissão e a primeira eucaristia).

Uma vez que os jovens participam da congada à sua maneira, trazem sua contribuição para o que já está posto, ainda que essa mudança seja vista pelos adultos ou por eles próprios como inadequada. Essa é a renovação que faz da cultura algo tão dinâmico.

\subsubsection{O que eu levo e como quero levar}


Nessa subcategoria, estão postas as falas dos jovens a respeito de como se relacionam com a tradição e com os mestres no ambiente de realização da congada. Em suas falas, aparecem também preocupações em torno da mudança provocada pelo seu ingresso e modo de participação no grupo. Contudo, tal preocupação não faz com que ajam de maneira diferente.

Ao fim da conversa sobre a inserção deles no grupo de congada e da atuação junto aos demais participantes, foi feito o agrupamento de algumas respostas da seguinte maneira: relação com os mestres; o que os mais velhos esperam dos jovens; como eles veem as mudanças que as novas gerações trouxeram para a congada.

Quando questionados sobre a proximidade deles com os mestres, dois responderam que têm mestres na sua família e que, por isso, relacionavam-se de modo mais próximo. Os outros três afirmaram não ter um contato direto com eles, exceto nos dias de festa e apresentação do grupo. O jovem A afirmou

Eu posso dizer que tenho mais relação com o mestre porque um deles é meu pai.

O jovem C, por sua vez, respondeu

\section{E eu tenho meu tio.}

Os jovens B, D e E não possuem grande proximidade com os mestres. O espaço em que teriam essa oportunidade seria durante os ensaios, mas esses jovens não participavam deles. Aliás, uma das queixas dos mestres é a falta de participação dos jovens nos encontros, o que dificulta a aprendizagem das músicas e dos instrumentos. Esse fator, de acordo com os mestres A e B e com a nossa anfitriã em Pinhões, a senhora a quem chamamos de MG, trazialhes preocupação porque, se os mais jovens não aprendessem o que era necessário, esse conhecimento morreria com os mais velhos.

O mestre A, por exemplo, já idoso, cego e com baixa audição, é o único do grupo a fazer a terceira das cinco vozes do coro. A preocupação é que essa geração se vá sem que os mais jovens tenham aprendido os elementos da congada tal como estão estabelecidos atualmente e isso leve à perda de identidade e das características atuais do grupo. Nesse sentido, quando perguntado aos jovens a respeito do que os mestres esperam deles, todos responderam algo bem semelhante. 
O jovem A, sobre essa pergunta, afirmou

Ah o mestre sempre espera né. Por exemplo, assim, eles esperam, eles pensam que como eles estão passando aquilo que eles aprenderam lá atrás para gente agora, pra não deixar isso acabar.

O jovem $\mathrm{B}$, a seu tempo, respondeu

Eles (os mestres) nos incentivam a continuar, a nunca parar. Pra gente que é novo eu acho que eles querem nos passar que nem sempre é brincadeira, que... igual, até eu mesmo já fiz bagunça na festa, mas em um momento, eu acho que eles querem passar pra gente que tem que ter a hora de tudo, a hora de ser sério ser sério, a hora de brincar, brincar.

O jovem $\mathrm{C}$, dentro da mesma linha de raciocínio, informou

Eles pedem para a gente aprender as músicas e os instrumentos.

Os jovens $\mathrm{C}$ e $\mathrm{E}$, ao mesmo tempo, completaram a frase afirmando

Por que a gente ainda não sabe cantar e nem tocar a viola ou a caixa.

O jovem A, que convive com um dos mestres em sua casa, ainda assim não se mostrou interessado em cantar ou tocar a viola (instrumento tocado por seu pai). Sobre esse fato, parece que há um adiamento por parte dos jovens em assumir algumas funções dentro da congada, mas afirmam que um dia o farão, pois é para eles quase uma obrigação. Se a seus avós e pais foi dada essa missão, naturalmente também será dada a eles. Desse modo, o jovem A continuou seu pensamento dizendo:

Em 2003, quando o meu avô já estava se sentindo meio mal aí falou assim pro meu pai: eu vou passar a viola pra você. Num ano tinha reformado a viola que meu avô tinha e no outro ano meu pai foi para Aparecida do Norte e comprou uma viola novinha para ele e até hoje ela tá com ele. Em 2004 meu avô foi e faleceu. Foram três ou quatro meses antes da festa, aí meu pai disse: nossa vou ter essa responsabilidade toda em cima de mim, vou ter que ir, querendo ou não eu vou ter que ir. Aí ele foi e tá aí até hoje. Não parou mais desde 2004 e já aprendeu as músicas todinhas, não sabia nada. Ele tem um caderno na casa dele que ele tem as músicas todinhas da festa de Nossa Senhora. Tudo, todas as músicas que canta na festa ele tem anotado. Aí tem vez que ele pega na viola, toca um pouquinho, aí ele vai pega o violão, tá sempre cantando alguma coisa, dá uma repassada, uma refrescada na memória. 


\section{O jovem D completou o raciocínio acima dizendo}

Vai chegar até nós, passar daqui de nós pra frente e assim sucessivamente passando para frente, para que continue o legado da festa de Nossa Senhora do Rosário.

Para os jovens parece que, em algum momento, vai ocorrer a passagem desse legado da geração anterior para a sua e então eles assumirão o papel que coube primeiro a seus avós, depois a seus pais e assim sucessivamente. Não têm pressa. Tal momento chega quando é inevitável, como aconteceu com o pai do jovem A, que é mestre. Com a morte do avô, o pai assumiu seu lugar e assim o jovem espera que aconteça também com ele.

Os jovens reconhecem que alguns comportamentos seus com relação às tradições ligadas à congada são considerados negativos pelos mestres. Os próprios jovens também se referem a alguns comportamentos seus de modo negativo. Nesse sentido, o jovem A informou

Essa festa assim bem dizendo antigamente era muito grande, era muita gente, era em torno de cem a duzentos dançantes. Quando eu comecei a dançar e tinha meus doze anos de idade era muita gente. Hoje se contar não tem nem cem dançantes. Eu sei que muita gente desistiu, outros faleceram, outros mudaram e desistiram de dançar, outros trocaram de religião, igual eu tenho dois amigos que trocaram de religião e eu acho que perderam a fé, acharam assim que a fé que eles tinham nela poderia... eles acharam uma fé maior do que a dela (Nossa Senhora do Rosário), aí desistiram de dançar. Mas, fazer o que né? Cada ser humano tem sua cabeça, ninguém manda no coração.

O jovem D, por sua vez, acrescentou

Na época do Sr. Reduzino e do meu avô não tinha bagunça, na Festa de Nossa Senhora do Rosário hoje tem bagunça, era cada um na sua fila, ele montava a fila de um lado, montava a fila do outro por tamanho, pra não ter menino novo lá atrás, menino novo lá na frente. Hoje a gente vê menino lá atrás, menino na frente, ele selecionava um por um e ficava de olho. Sempre ficava olhando pra ver que estava fazendo bagunça. Quem tivesse fazendo bagunça ele ia lá e dava um puxão de orelha, chamava a atenção. Pra mim a festa de Nossa Senhora do Rosário de hoje não tem organização.

O jovem B complementou o pensamento acima afirmando

Os jovens, os meninos mais novos, não digo eles (apontando para os colegas), acham que a festa de Nossa Senhora do Rosário é brincadeira, mas não é. Acha que tá vestindo a roupa para brincar, fica fazendo poeira, tacando barro nos outros, mas não é assim. 
O jovem A voltou então a se manifestar dizendo

Tudo tem seu tempo e sua hora. Hora de brincar é de brincar, hora da festa é hora da festa, vai ter o momento certo de você parar e descansar aí você faz o que você quiser, eu digo por eu mesmo, eu desde 2008 eu não escuto a missa, cumpro minha promessa e quando dá três horas eu falo: mãe, agora só amanhã, eu paro, eu não escuto a missa, raramente eu venho na procissão, mas a missa das três eu não escuto, eu vou embora, volto pra casa, tomo um banho e saio, mas não escuto a missa. Mas o compromisso que eu tenho com ela de oito da manhã até as três eu cumpro normal. Cumpro a minha promessa, as trinta e tantas rodadas em volta da igreja eu cumpro todas, mas assim que termina e começa a missa eu vou para minha casa. Troco de roupa, visto a outra roupa, tomo um banho descanso um pouco e aí saio de novo.

Ao mencionar seu ato de não participar da missa, os outros jovens foram um a um dizendo do que participavam ou não. Ao todo são sete missas durante os três dias de festa, fora as missas que ocorrem durante todos os meses do ano em preparação à comemoração do dia de Nossa Senhora do Rosário. Eles afirmaram ser cansativo, e por hora desinteressante, participar de todos os eventos relacionados à festa. Desse modo justificaram o fato de não seguirem a tradição referente à participação em todas as etapas desse evento.

Os jovens demonstram em suas falas que, em muitos aspectos, o comportamento deles difere-se daquele que é esperado por parte dos mestres e de seus familiares. Eles próprios julgam algumas de suas ações como inadequadas quando comparadas ao que tradicionalmente deve ser feito pelos membros do grupo. Afirmam que há algumas perdas para a festa de Nossa Senhora do Rosário por causa dessas ações dos jovens, inclusive deles mesmos, mas sentem também que a seu modo contribuem para que o essencial, como a fé, por exemplo, não se perca com o tempo.

Se for levado em consideração o caráter de mutabilidade da cultura, é perfeitamente compreensível que as novas gerações tragam transformações para o meio onde convivem. Em se tratando de tradição, no sentido que foi estabelecido por Hanna Arendt (2013) e trabalhado aqui, também é fácil compreender que o legado deixado por gerações anteriores não será levado para o futuro sem que um novo caminho tenha sido "pavimentado" pelos jovens.

\subsubsection{Ser quilombola, ser negro}


Nessa subcategoria, estão postas as falas dos adultos (dos mestres e da moradora da comunidade, chamada aqui de MG) e também dos jovens, a respeito dos elementos da cultura africana presentes na congada, da condição deles como pessoas negras e da origem quilombola do vilarejo de Pinhões. Em suas falas, de modo geral, apareceram a rejeição da ideia de que são quilombolas e a inexistência de preconceito com relação ao fato de serem negros (tanto por parte deles, quanto por parte das pessoas com as quais eles se relacionam fora de Pinhões).

Os dois mestres contaram que, no passado, há algumas décadas, havia mais diálogo sobre o fato de o vilarejo ser um quilombo. À época, existiam discussões em nível nacional sobre o reconhecimento das terras ocupadas por pessoas negras como remanescentes de quilombo. Na fala do mestre B:

Tem algum tempo que as pessoas falavam mais disso aqui na associação de moradores. Na época tinha umas coisas do governo... de leis assim que iam beneficiar o lugar se fosse considerado quilombo. O que as pessoas contam é que aqui foi formado na época por escravos que vinham de Santa Luzia e de Macaúbas, do convento. Mas a associação foi ficando fraca, sem ninguém pra representar aí o propósito acabou.

Já a moradora da comunidade, MG, informa que ouve a história da fundação de Pinhões como um quilombo desde sua infância, mas que as pessoas não costumam mencionar isso no dia a dia e nem se preocupar com esse fato. Além disso, os moradores, principalmente os jovens do vilarejo, não gostam de serem lembrados como quilombolas. MG afirma

Desde minha infância ouço os mais velhos falando desse negócio de quilombo, então acho que é verdade. Mas o povo aqui, principalmente os jovens não gostam de serem chamados de quilombola. Acho que é porque lembra escravidão e a gente é colocado abaixo dos outros.

Aos jovens foi lançada também a pergunta sobre Pinhões ser um quilombo, e eles responderam algo bastante semelhante ao que o jovem B disse:

A gente mesmo não fala quilombo ou quilombola. Isso é história né, o povo fala isso aí.

O jovem $\mathrm{D}$, por sua vez, informou 
Aqui ninguém fica falando de quilombo ou lembrando que já foi quilombo, não tem esse costume. Nem aqui e nem fora.

Com relação ao que foi citado pelos adultos, é importante destacar que eles conhecem a história contada pelas gerações anteriores sobre a formação de Pinhões no contexto da escravidão. Concordam com o fato de que a comunidade pode ter nascido como um quilombo, mas essa denominação começou a ser mencionada quando foram estabelecidas pelo governo leis de reconhecimento para as terras quilombolas, o que poderia trazer para o local algumas vantagens com relação aos impostos e às políticas públicas. Até então, as memórias sobre a fundação do vilarejo por escravos fugidos só costumava ser mencionada em rodas de conversa nas quais os mais velhos falavam com seus filhos e netos sobre esse assunto.

Os jovens, por sua vez, afirmam que isso é apenas história, mas que não se importam ou não se preocupam em serem chamados assim, são indiferentes a isso. Afirmaram também que não costumam ouvir ou falar na questão do local de sua residência ser um quilombo.

A nomenclatura de quilombo surgiu justamente no contexto de reconhecimento das terras quilombolas pelo Governo Federal. O termo foi introduzido de fora para dentro da comunidade e por isso não faz muito sentido para os mais jovens. Eles conhecem as histórias contadas pelos mais velhos, mas não se mencionava o nome quilombo, apenas falavam a respeito dos escravos que haviam fugido das fazendas vizinhas e formado Pinhões.

No que se refere ao fato de serem pessoas negras e de que a congada e a festa de Nossa Senhora do Rosário são de tradição negra, com elementos da cultura africana associadas ao Cristianismo, o mestre A informou

O que eu sei é que a congada tá ligada com as irmandades que tinham em Minas há muito tempo. Que a irmandade de Nossa Senhora do Rosário geralmente era de pessoas negras, dos escravos.

De fato, em Minas Gerais, ainda no século XVIII, a existência de ordens terceiras, ou ordens de leigos, que ficaram responsáveis por cuidar da construção e conservação de igrejas e capelas, bem como por fazer as celebrações após a expulsão dos religiosos da região mineradora, fortaleceram as festas ligadas à tradição cristã. A presença de grande número de escravos favoreceu o aparecimento de ordens leigas entre essa população, o que contribuiu também para fomentar as festas ligadas aos santos de devoção dos negros. 
Quando perguntado também aos jovens sobre sua condição de pessoas negras que participam de uma festa ligada às tradições africanas. Todos responderam à pergunta de maneira semelhante. $\mathrm{O}$ jovem $\mathrm{C}$ afirmou

Não tem muito isso aqui não. Acho que ninguém pensa se é festa de negro ou de branco. Só que aqui a maioria é negra, só isso.

O jovem A expressou seu pensamento dizendo

Eu não vejo que tem preconceito ou coisas assim não e se tiver a gente também nem se importa.

Não há por parte dos jovens uma preocupação em ser uma festa com elementos da cultura africana. Eles não demonstraram preocupação ou conhecimento sobre a história da festa de Nossa Senhora do Rosário e da congada. Por suas falas ao longo da entrevista foi possível notar que eles se ocuparam mais em falar o que a festa e a congada representam para eles no presente. E, nesse caso, não há por parte dos jovens inquietações relacionadas a serem negros, quilombolas ou qualquer outra denominação que possa ser utilizada com relação a eles. Outra possibilidade é a de que, por causa de preconceitos sofridos pela população negra no contexto brasileiro, eles prefiram evitar o assunto ou não se importar com ele, como uma forma de defesa. De qualquer modo, será mantida a atenção apenas ao que está expresso em suas falas.

\subsubsection{Ao futuro, esperança...}

Para fechar a análise das falas aqui proposta, são apresentadas as respostas à última questão levantada para o grupo de jovens, sobre os seus planos futuros relacionados ao grupo de congada. Em suas respostas, para além de qualquer olhar que os julgue com dureza por suas posturas diante da tradição, aparece a ideia de esperança. Esperança de que a congada, a festa e a própria tradição não deixem de existir. Na fala do jovem $\mathrm{C}$, a expectativa é de

Que a festa e a Congada não acabe né, até porque nós mesmos não deixamos acabar né.

O jovem A, em complementação à fala anterior, afirmou 
Que nós jovens que estiver por aí tenham mais responsabilidade com a festa. Que isso aí é o marco da história de Pinhões. A festa dela é pra Pinhões. Tudo que acontece aqui volta sempre para a comunidade. Que não deixe isso acabar porque se acabar é a história que vai se acabar. O foi passado dos nossos avós para nossos pais e de nossos pais para nós e de nós para nossos filhos e assim sucessivamente pra frente.

Os jovens se inserem na cultura de modo distinto das gerações anteriores, foi possível confirmar. Não pelo fato de serem transgressores ou ameaçadores do status quo. O contato com as mudanças trazidas pelas novas tecnologias, pelo crescimento das grandes cidades, pelo esvaziamento do campo associado às difíceis condições de vida nesse ambiente, entre outros fatores que cercam os jovens de Pinhões, fazem com que eles se relacionem com os fatores culturais tradicionais da comunidade de uma nova maneira.

Os jovens reconhecem a importância de se manter viva a memória dos seus antepassados e conservar a cultura de sua comunidade. Sua postura às vezes relapsa com relação às tradições e às regras existentes na congada e no ciclo das festas de Nossa Senhora do Rosário, o que se justifica pelas próprias características da condição juvenil já mencionada no início deste trabalho, não invalidam o desejo deles de que haja continuidade em seu universo cultural. Uma última frase que justifica o nome dado à subcategoria que fecha este trabalho "ao futuro, a esperança":

Enquanto Deus me der vida eu vou estar aí... (Jovem B) 


\section{CONSIDERAÇÕES FINAIS}

Ao iniciar este trabalho, estabeleceu-se como objetivo geral investigar as relações que a juventude estabelece com os processos educativos caracterizados por trocas de saberes, crenças e tradições no espaço da manifestação cultural da Congada no remanescente de quilombo em Pinhões - MG. Como objetivos específicos, têm-se os seguintes: investigar o que é a juventude e de que modo ela se relaciona com a cultura e a educação; identificar quais são as crenças, saberes e tradições trocadas no ambiente da congada; compreender o que os adultos esperam do jovem e o que estes esperam de si mesmos quanto à sua ligação com a tradição.

A partir desses objetivos, partiu-se para a investigação na literatura sobre os temas aqui tratados a fim de identificar quem é o jovem, que parâmetros são utilizados para definir a juventude. Buscou-se também compreender de que modo tem sido tratada a relação dos jovens com a cultura e a educação. Em seguida, procurou-se identificar o que é a congada, manifestação cultural que serve de base para esta investigação e apresentar os elementos tradicionais a ela.

Em vista dos conceitos trabalhados na primeira parte deste trabalho, foram coletados os dados para a análise aqui proposta. Utilizou-se como ferramenta a entrevista individual, o grupo focal e a observação. O quarto capítulo, então, traz a apresentação da comunidade de Pinhões, da festa do congado, do grupo de jovens entrevistados, dos dados coletados e sua análise.

A primeira categoria estabelecida, "Jovens da Congada de Pinhões: quem são? Por que são?", trabalha a ideia de que os parâmetros para se estabelecer quem são os jovens podem ser muito distintos dependendo de como é a relação entre as diferentes gerações e do meio em que essas pessoas vivem. Desse modo, procurou-se compreender quem era o jovem de Pinhões de acordo com a fala dos adultos, com as características da comunidade e de seus arredores e com as falas dos próprios jovens. 
A conclusão a que se pode chegar é de que de fato a juventude pode ser caracterizada de diversas maneiras e que, para compreender esse termo em espaço e tempo determinados, é necessário identificar, por meio das características do ambiente e pela fala das próprias pessoas, quem consideram ser o jovem.

A segunda categoria estabelecida trata do modo como o jovem se relaciona com a cultura em que está imerso. Para compreender essa relação, foi importante perguntar aos adultos como eles viam a participação dos jovens nas atividades cotidianas da comunidade, sobretudo da congada. Essa pergunta também foi lançada aos próprios jovens, que indicaram o porquê de sua participação no grupo de congada e nas festas religiosas tradicionais da comunidade.

Foi possível identificar que de fato as pessoas não participam de todos os aspectos de sua cultura e que cada um tem razões particulares para dedicar-se a determinada atividade dentro do ambiente em que vive. Os jovens associaram sua participação na congada à devoção a Nossa Senhora do Rosário, à necessidade de manter a tradição, ao gosto pela festa e pela diversão, à visibilidade que o grupo tem dentro da comunidade.

A terceira categoria desenvolvida refere-se às práticas educativas dentro do ambiente cultura de Pinhões, mais especificamente dentro do grupo de congada. Essa categoria apresenta um interesse especial. A conversa com os mestres permitiu concluir que eles têm o desejo de servir de exemplo para os jovens. Em sua fala, transparece o objetivo de colocaremse como espelho para os mais jovens, mantendo a devoção, o respeito, a tradição e a ajuda mútua, valores que apareceram em diversos momentos em suas falas.

Com relação aos jovens, suas falas demonstram que eles reconhecem os mais velhos como um exemplo, valorizam as tradições, a devoção, a solidariedade. Ficou claro que eles não consideram interessante a repetição de atividades propostas nos ensaios e que, uma vez aprendido o que consideram necessário para sua inserção no grupo e participação nas festas, eles normalmente não se dispõem a agir conforme os mais velhos esperam. Demonstraram também preocupação com relação ao desaparecimento das tradições pela negação em aprenderem alguns elementos como as músicas e os instrumentos e, nesse caso, eles reconhecem que haverá um momento em que eles terão de assumir o lugar das gerações anteriores e que certamente o farão, mas aquele ainda não era o momento. 
No que se refere à compreensão da dimensão educativa presente em um ambiente cultural em que adultos e jovens se relacionam com a intenção de manter o status quo, de levar a tradição adiante, foi possível identificar que, na maioria das vezes, as intenções dos mais velhos não coincidem com as dos mais jovens. Contudo, os jovens entrevistados poderiam estar em qualquer outro lugar, desenvolvendo qualquer outra atividade e escolheram estar entre aqueles que mantêm vivas as tradições de sua comunidade. Essa ideia de inserção no universo da tradição é apresentada na quarta e última categoria.

Então, na quarta categoria, traz-se um conjunto de ideias em torno do que os adultos esperam do jovem com relação à cultura e à tradição locais, bem como a fala dos próprios jovens sobre sua relação com esses elementos. Os adultos demonstraram em suas falas que esperam que o jovem possa de fato carregar a tradição para o futuro. Nas falas dos mestres e da moradora da comunidade, aparece muitas vezes o pesar pela perda de alguns elementos que consideravam tradicionais (associados à congada e às festas da comunidade). Atribuem esse fato às mudanças que os mais jovens impõem àquilo que já está posto, considerando tal acontecimento como algo negativo. Seu grande desejo é que os jovens pudessem manter sua participação dentro do que era feito décadas antes.

Os jovens também consideram negativas algumas de suas posturas que trazem mudança para a cultura local. Parece que o fato de viverem em uma comunidade pequena e ouvirem dos mais velhos que a mudança deteriora a tradição faz com que eles internalizem essa ideia e expressem em suas falas. De qualquer forma, sua ação contraria sua fala. Se de fato considerassem a mudança algo negativo, provavelmente não agiriam de modo a transformar a cultura em algo novo. O que fazem é imprimir ao mundo em que vivem características novas que vão ao encontro de uma visão de mundo singular - sua visão de mundo que é diferente daquelas que tinham as gerações anteriores.

Por fim, foi possível compreender que, entre adultos e jovens, no contexto cultural de Pinhões, as práticas educativas estão baseadas na vontade e na liberdade. Quanto à vontade, pode-se afirmar que o grupo de jovens entrevistado optou por estar naquele e não em outro ambiente; optou por carregar a essência das tradições de sua comunidade para o futuro e não deixar que elas se perdessem com o tempo; escolheu, é certo, o que levar, impondo ao seu ambiente cultural características novas, renovando a própria vida. Quanto à liberdade, nota-se que aos jovens entrevistados não foi imposta essa ou aquela condição para que entrassem ou permanecessem no grupo, para que aprendessem esse ou aquele valor ou exercessem uma 
atividade específica. Os mestres indicam, com seu exemplo, o que gostariam que os jovens aprendessem; estes, por sua vez, sentem-se acolhidos mesmo escolhendo carregar um pouco do que aprenderam com os mais velhos e acrescentar a esse legado algo novo.

Enfim, foi possível confirmar por meio deste trabalho que, em se tratando de educação (nomeadas aqui de práticas educativas), cada pessoa acaba carregando aquilo que está de acordo com sua vontade. O acolhimento e o respeito são os princípios que norteiam uma relação saudável entre quem ensina e quem aprende. 


\section{REFERÊNCIAS BIBLIOGRÁFICAS}

ABRAMO, Helena Wendel. O uso das noções de adolescência e juventude no contexto brasileiro. In: Freitas, Maria Viriginia de (Org.) Juventude e adolescência no Brasil: referências conceituais. São Paulo: Ação Educativa, 2005. p. 19-35.

Helena Wendel. Considerações sobre a tematização social da juventude no Brasil. In: FÁVERO, Osmar et al. Juventude e contemporaneidade. Brasília: UNESCO/MEC/ANPED, 2007.

AFONSO, Almerindo Janela. Sociologia da educação não formal: reactualizar um objeto ou construir uma nova problemática? In: ESTEVES, A. J.; STOER, S. R. A sociologia na escola. Porto: Afrontamento, 1989. p. 83-96.

ANDRADE, Mário de. Danças dramáticas do Brasil. Belo Horizonte: Itatiaia, 2000.

ARENDT, Hannah. Entre o passado e o futuro. São Paulo: Perspectiva, 2013.

BARBER-MADEN, Rosemary; SABER, Bruno Abe. A situação dos jovens no mundo. In: BARBER-MADEN, Rosemary; SANTOS, Taís de Freitas. A juventude brasileira no contexto atual e em cenário futuro. Brasília: Universidade de Brasília, 2010.

BASTIDE, Roger. Sociologia do folclore brasileiro. In: Sociologia do folclore brasileiro. São Paulo: Anhambi, 1959.

BOTO, Carlota. Na Revolução Francesa, os princípios democráticos da escola pública, laica e gratuita: o relatório de Condorcet. Educ. Soc., Campinas, v. 24, n. 84, p. 735-762, set. 2003. 
BRANDÃO, Carlos Rodrigues. O que é folclore. São Paulo: Brasiliense, 1984.

Brasil. Ministério da Saúde. Pesquisa Nacional de Demografia e Saúde da Criança e da Mulher - PNDS 2006: dimensões do processo reprodutivo e da saúde da criança/ Ministério da Saúde, Centro Brasileiro de Análise e Planejamento. Brasília: Ministério da Saúde, 2009.

BUBER, Martin. Sobre comunidade. São Paulo: Perspectiva, 1987.

CÂMARA CASCUDO, Luís da. Dicionário do folclore brasileiro. 9 ed. Rio de Janeiro: Ediouro, 2000.

CHARLOT, Bernard. Da Relação com o Saber: elementos para uma teoria. Porto Alegre: Artmed, 2000.

CONTRERAS, Rolando N. Pinto. Os programas de educação não formal como parte integrante do processo de educação e de organização popular. Em Aberto, Brasília, ano 2, n. 18, ago./nov. 1983.

DAYRELL, Juarez et al. Juventude e escola. In: SPÓSITO, Marília P. O estado da arte sobre juventude na pós-graduação brasileira: Educação, Ciências Sociais e Serviço Social (1999-2006). v. 1. Belo Horizonte: Argumentum, 2009. p. 57-126.

DE ANDRADE, Mário. Danças dramáticas do Brasil. Belo Horizonte: Editora Itatiaia, 2000.

DE SOUZA, Candida; DE PAIVA, Ilana Lemos. Faces da juventude brasileira: entre o ideal e o real. Estudos de Psicologia, v. 17, n. 3, p. 353-360. 2012.

DOS SANTOS, Carlos Roberto Moreira. Congada e reinado: história religiosa da irmandade negra em Jequitibá - MG. 2011. Dissertação Mestrado em Ciências da Religião - Programa de Pós-graduação em Ciências da Religião, Pontifícia Universidade Católica de Minas Gerais, Belo Horizonte.

ESTEVES, Luiz Carlos Gil; ABRAMOVAY, Miriam. Juventude, juventudes: pelos outros e por elas mesmas. In: Juventudes: outros olhares sobre a diversidade, 2007. Disponível em: http://www.juventude.gov.br/conjuve/documentos/juventude-e-diversidade. p. 21-56. 
FÁVERO, Osmar. Educação não formal: contextos, percursos e sujeitos Educ. Soc., Campinas, v. 28, n. 99, p. 614-617, maio/ago. 2007.

FONTOURA, Natália de Oliveira; PINHEIRO, Luana S. Síndrome de Juno: gravidez, juventude e políticas públicas. In: CASTRO, Jorge Abrahão de. et al. (Orgs.) Juventude e políticas sociais no Brasil. Brasil: IPEA, 2009.

GEERTZ, Clifford. A interpretação das culturas. In: A interpretação das culturas. Rio de Janeiro: LTC, 1989.

GHON, Maria da Glória. Educação não formal e cultura política. São Paulo: Cortez, 1999.

GOMES, Núbia Pereira de Magalhães; PEREIRA, Edimilson de Almeida. Negras raízes mineiras: os Arturos. Belo Horizonte: Mazza, 2000.

GROPPO, Luís Antonio. Juventude: ensaios sobre sociologia e história das juventudes modernas. Rio de Janeiro: DIFEL, 2000.

HALL, Stuart. A centralidade da cultura: notas sobre as revoluções culturais do nosso tempo. Disponível em: www.ufrgs.br/neccso/word/texto_stuart_centralidacult ura.doc. Acesso em 14 de abril de 14 às $12 \mathrm{~h} 45$.

HERNANDEZ, Aline Reis Calvo. Atravessando o portão. Percorrendo significados e características da educação não formal nas vivências de agentes comunitários. Porto Alegre: PUCRS, 2002.

IANNI, Otávio. O jovem radical. In: BRITTO, Sulamita de (Org.). Sociologia da juventude I. Rio de Janeiro: Zahar, 1968.

ILLICH, Ivan. Sociedade sem escolas. Tradução de Lucia Mathilde Orth. 6. ed. Petrópolis: Vozes, 1982.

KEHL, Maria Rita. A juventude como sintoma da cultura. In: NOVAES, Regina; VANNUCHI, Paulo. Juventude e sociedade: trabalho, educação, cultura e participação. São Paulo: Fundação Perseu Abramo, 2004. 
LARAIA, Roque de Barros. Cultura: um conceito antropológico. Rio de Janeiro: Zahar, 2009.

LEÓN, Oscar Dávila. Adolescência e juventude, das noções às abordagens. In: Freitas, Maria Viriginia de (Org.) Juventude e adolescência no Brasil: referências conceituais. São Paulo: Ação Educativa, 2005. p. 9-18.

MANNHEIM, Karl. O problema da juventude na sociedade moderna. In: idem, Diagnóstico de nosso tempo. Rio de Janeiro: Zahar, pp. 36-61.

MORAES, Eduardo J. de. Modernismo e Folclore. In. Seminário de folclore e cultura popular. Série encontros e estudos I. Rio de Janeiro: FUNARTE, 2000. p. 75-78.

NOVAES, Regina. Os jovens de hoje: contextos, diferenças e trajetórias. In: ALMEIDA, Maria Isabel Mendes; EUGENIO, Fernanda. Culturas jovens: novos mapas do afeto. Rio de Janeiro: Jorge Zahar, 2006. p. 253-281.

PERALVA, Angelina. O jovem como modelo cultural. In. FÁVERO, Osmar et al. (Orgs.). Juventude e contemporaneidade. Brasília: UNESCO, MEC, ANPEd, 2007. p. 13-45.

RYLE, Gilbert. What is le penseur doing? Disponível em: http://lucy.ukc.ac.uk/CSACSIA/Vol14/Papers/ryle_1.html. Acesso em 22 de maio de 14 as $22 \mathrm{~h} 32$.

SABÓIA, Ana. A população jovem no Brasil metropolitano. In: BARBER-MADDEN, Rosemary; SANTOS, Taís de Freitas (Orgs.). A juventude brasileira no contexto atual e em cenário futuro. Brasília: Universidade de Brasília, 2010. p. 42-64.

SPOSITO, Marília Pontes. Juventude, pesquisa e educação. 24 ${ }^{\mathrm{a}}$ Reunião Anual da Associação de Pós-Graduação e Pesquisa em Educação, 2001, Brasília: INEP.

A pesquisa sobre jovens na pós-graduação: um balanço na produção discente em Educação, Serviço Social e Ciências Sociais (1999-2006). In: idem, O estado da arte sobre juventude na pós-graduação brasileira: Educação, Ciências Sociais e Serviço Social (1999-2006). Belo Horizonte: Argumentum, 2009. 
TINHORÃO, José R. Cultura popular temas e questões. São Paulo: Ed. 34, 2001.

TUNES, Elizabeth. É necessária a crítica radical à escola. In: Idem, Sem escola, sem documento (Org.). Rio de Janeiro: E-papers, 2011. p. 9-14.

; PEDROZA. O silêncio ou a profanação do outro. In: idem, Sem escola, sem documento (Org.). Rio de Janeiro: E-papers, 2011. p. 15-30.

UNESCO. Políticas públicas de/para/com as juventudes. Brasília: UNESCO, 2004.

VIGOTSKI, Lev S. Psicologia pedagógica. São Paulo: Martins Fontes, 2010.

VON SIMSON, Olga Maria de Moraes et al. Educação não-formal: um conceito em movimento. In: Visões singulares, conversas plurais. São Paulo: Instituto Itaú Cultural, 2007. p. 13-42. 